\title{
norden
}

Nordic Council of Ministers

\section{Nordic nature - trends towards 2010}

Examples of Nordic contributions towards the international biodiversity target 2010

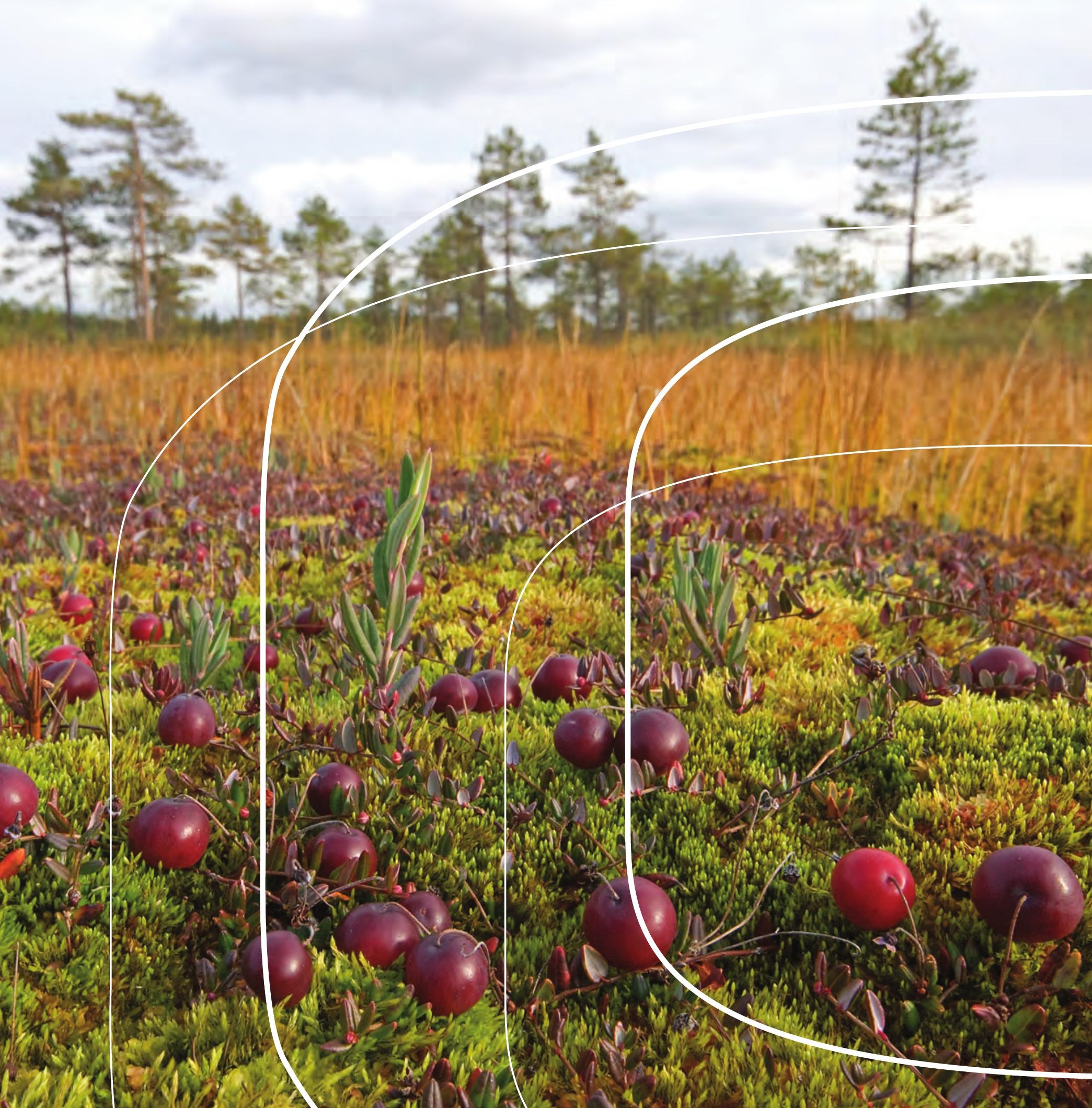



4 norden 



\section{Nordic nature - trends towards 2010}

Examples of Nordic contributions towards the international biodiversity target 2010

Marja Pylvänäinen

TemaNord 2010:509 
Nordic nature - trends towards 2010

Examples of Nordic contributions towards the international biodiversity target 2010

TemaNord 2010:509

(c) Nordic Council of Ministers, Copenhagen 2010

ISBN 978-92-893-1992-8

Print: Rosendahls Bogtrykkeri AS

Cover photo: Markku Mannonen/Kuvaliiteri

Copies: 630

Printed on environmentally friendly paper

This publication can be ordered on www.norden.org/order. Other Nordic publications are available at www.norden.org/publications

Printed in Denmark

Nordic Council of Ministers

Store Strandstræde 18

DK-1255 Copenhagen K

Phone (+45) 33960200

Fax (+45) 33960202

www.norden.org

\section{Nordic Council}

Store Strandstræde 18

DK-1255 Copenhagen K

Phone (+45) 33960400

Fax (+45) 33111870

\section{Nordic co-operation}

Nordic co-operation is one of the world's most extensive forms of regional collaboration, involving Denmark, Finland, Iceland, Norway, Sweden, and three autonomous areas: the Faroe Islands, Greenland, and Åland.

Nordic co-operation has firm traditions in politics, the economy, and culture. It plays an important role in European and international collaboration, and aims at creating a strong Nordic community in c strong Europe.

Nordic co-operation seeks to safeguard Nordic and regional interests and principles in the global community. Common Nordic values help the region solidify its position as one of the world's most innovative and competitive. 


\section{Contents}

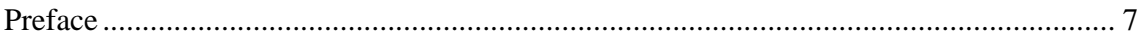

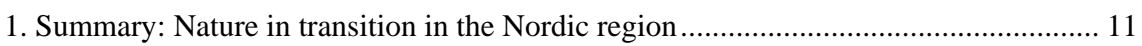

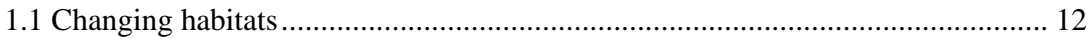

1.2 Many species dependent on conservation measures ............................................ 14

1.3 Opportunities to save threatened species ............................................................. 16

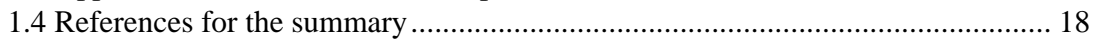

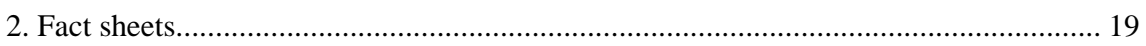

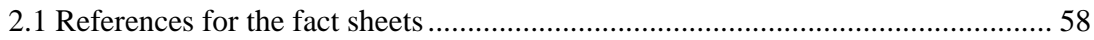

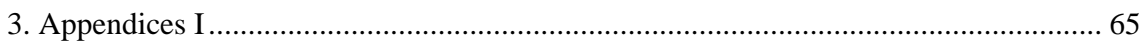

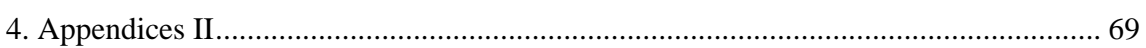

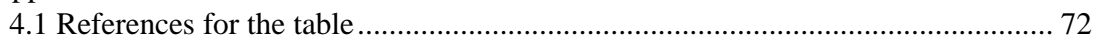





\section{Preface}

The UN has declared 2010 as the International Year of Biodiversity, to spotlight the fact that biodiversity is in decline all around the world - and because targets have been set both by the European Union and in the UN's Convention on Biological Diversity (CBD) that by the end of the year 2010 the ongoing decline in biodiversity should be halted.

The UN's biodiversity target was defined at a conference of parties to the CBD held in 2002. During the same year, world leaders at the World Summit on Sustainable Development in Johannesburg resolved to reduce biodiversity loss by 2010. The target is also included in the Nordic Council of Ministers' Environmental Action Plan for 2009-2012. The Countdown 2010 initiative launched by the International Union for Conservation of Nature (IUCN) and the EU Commission's has also been striving to meet this target. The project Nordic nature - trends towards 2010 is part of this wider Countdown 2010 initiative.

The concept of biodiversity encompasses all life on Earth. Biodiversity is often considered to exist at four different levels: genetic diversity, species diversity, ecosystem diversity and landscape diversity. The biodiversity of our planet is vital for our own lives, and we must ensure that it is preserved.

Biodiversity is also declining rapidly at global level and within the Nordic Countries. Halting this decline by 2010 is a key goal of current Nordic environmental cooperation guided by the Environmental Action Plan. The Nordic Council of Ministers funds projects that work towards this programme's goals and publicise related biodiversity issues.

Accurate information helps us understand and respect our irreplaceable nature. The communications project Nordic nature - trends towards 2010, funded by the Nordic Council of Ministers' Terrestrial Ecosystem Group (TEG) over the period 2007-2009, has produced a series of fact sheets covering various aspects of the state of biodiversity in the Nordic Countries and related trends and threats. The project group has not sought to give a complete picture of biodiversity in the Nordic Countries, but to focus on individual biodiversity conservation success stories, as well as other stories describing negative trends that have not yet been successfully halted. The fact sheets have striven to comprehensively cover the main threats to Nordic biodiversity and describe their impacts.

The project and the members of the project group have been actively publicizing issues related to the biodiversity of the Nordic Countries in various ways both nationally and internationally. The electronic fact sheets produced by the project have been published on the project's home pages in all the Nordic languages and in English, to facilitate their 
educational use and wider dissemination. The project group chose to focus on the electronic media as an easy way to distribute information widely using the internet and email. The fact sheets provide condensed information on a set of carefully selected issues, and readers can easily get access to further information through the links provided to other websites. The fact sheets have been made freely available for printing and downloading as they have been produced. The project's home pages and the fact sheets will remain on the web for at least the duration of the International Year of Biodiversity 2010.

The publication of each new fact sheet has been publicised through newsletters distributed among a wide target group throughout the Nordic Countries. Information on the project's fact sheets and home pages was also regularly distributed via e-mail, postcards and advertisements in magazines. Press releases and related articles were also produced in connection with the themes of the fact sheets. Links have been set up between the project's home pages and various other organisations' web services. The project and its information output have also been presented at various national and international seminars and other events throughout the Nordic Countries and Europe.

To mark the International Year of Biodiversity 2010 the project has produced a calendar illustrated with photographs of Nordic nature to remind users of the importance of conserving nature throughout this landmark year.

This report includes all of the fact sheets produced during the project as they appear on the project's home pages, where they can also be printed or downloaded. This publication has been printed in English and Danish. Electronic publications can be downloaded from the websites of the Nordic Council of Ministers and from the project's home pages.

It has not been possible to halt the ongoing decline in biodiversity as we approach 2010, but our efforts to reach this target have nevertheless been well publicised, and this has increased public awareness of the need to conserve biodiversity and to only exploit natural resources in sustainable ways. Many practical projects have been initiated and implemented around the Nordic Countries. New international goals will be defined during 2010.

The fact sheets, home pages and other materials produced as part of the Nordic nature - trends towards 2010 project, including this report, all form part of the Nordic Countries' contribution towards the global 2010 target, and the goal of building awareness of the vital importance of biodiversity. 
The project group members and their organisations:

- Marja Pylvänäinen, Finnish Environment Institute SYKE, project leader

- Sonja Forss, Finnish Environment Institute SYKE, project assistant

- Tine Nielsen Skafte and Kasper Gade, Agency for Spatial and Environmental Planning, Denmark

- Sissel Rübberdt and Lars Ekker, Directorate for Nature Management, Norway

- Mark Marissink, Anna Lind and Anna Ellström, Swedish Environmental Protection Agency

- Trausti Baldursson, Karl Karlsson and Hildur Vésteinsdóttir, The Environment Agency of Iceland

- Anna Maria Fosaa, Beinta Johannesen and Herborg Nyholm Debess, Faroese Museum of Natural History

- Inge Thaulow and Peter Nielsen, Government of Greenland

The project group wishes to thank everyone who has contributed their knowledge, expertise and photographs to help us produce the fact sheets - particularly Hans Skotte Møller from the Danish Agency for Spatial and Environmental Planning, for his many constructive ideas. The project group hopes that biodiversity will continue to be cherished and that awareness of its practical importance to all of us will increase further, also after the International Year of Biodiversity 2010.

Helsinki, Copenhagen, Trondheim, Stockholm, Reykjavik and Torshavn, 28 January 2010

Marja Pylvänäinen, project leader 
Websites of the project and participating organisations:

- Finnish Environment Institute SYKE [www.environment.fi]. Project's home page [www.environment.fi/nordicnature]

- Directorate for Nature Management, Norway [www.dirnat.no] Project's home page [http://www.dirnat.no/naturmangfold/internasjonalt/ norden/nordiske_trender_2010/]

- Agency for Spatial and Environmental Planning, Denmark [www.blst.dk] Project's home page [www.blst.dk/Biodiversitet/Nordensnatur]

- Government of Greenland [www.nanoq.gl]

- Faroese Museum of Natural History [www.ngs.fo] Project's home page [http://www.ngs.fo/Default.aspx?ID=9442]

- The Environment Agency of Iceland [www.ust.is] Project's home page [www.ust.is/Natturuvernd/liffraedilegfjolbreytni/ natturanordursins]

- Swedish Environmental Protection Agency [www.naturvardsverket.se]

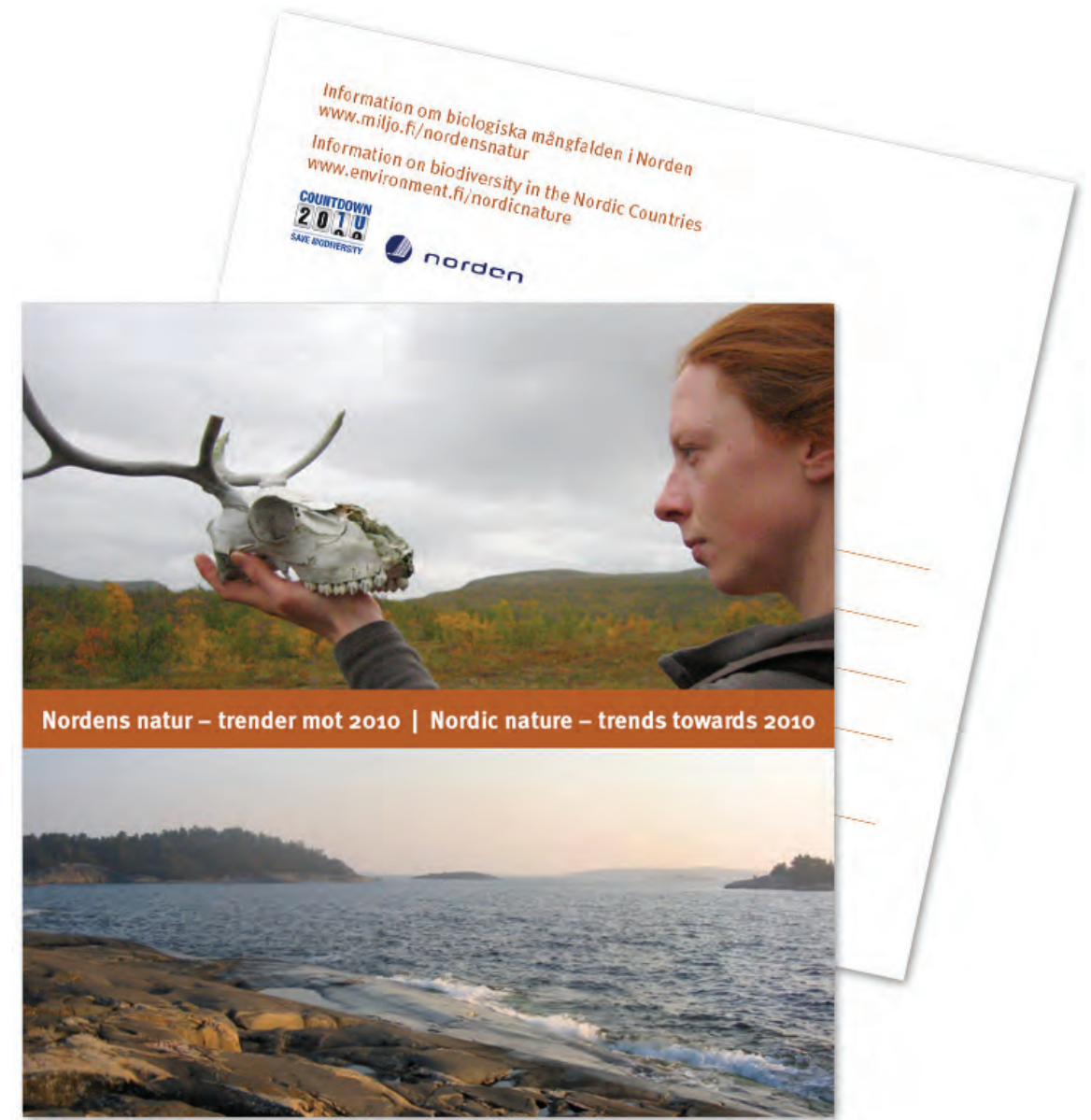

Postcards were distributed widely to publicise the project and its products - the fact sheets describing trends and status of the biological diversity in the Nordic Countries. Photographs by Sonja Forss (upper) and Satu Turtiainen (lower). 


\section{Summary: Nature in transition in the Nordic region}

Traces of man are visible everywhere in the Nordic Countries, but the scale of our impact on the natural environment has varied greatly over time and from place to place. In addition to physical conditions such as climate, topography and soil fertility, local land use traditions and cultural history have also largely influenced the intensity at which we have exploited natural resources. Some regions' original natural features have vanished completely, but in other areas the more superficial scars left by man have largely healed.

Throughout history people have changed the natural environment by farming the land, exploiting forest resources and building our homes and infrastructure. Changes in the ways we use the land are the most serious causes of habitat loss. Habitats may become unsuitable for species due to intensive farming and forestry, construction, drainage schemes, earthworks and landfill, the dredging and dumping of sediments, mining, the overgrowth of open habitats and overgrazing, with its consequent weathering and erosion. Such physical changes in land use directly affect habitats, worsening the survival prospects of their characteristic species. In some cases the impacts of land use can be positive in terms of biodiversity, for instance where traditional agricultural biotopes are kept open by moderate grazing.

Our excessive exploitation of natural resources may destroy habitats or degrade them so that they are no longer suitable for species. Species are increasingly coming under pressure as their habitats shrink and deteriorate. Climate change and competition from invasive alien species further increase the risk of extinctions. Competition between species for shrinking areas of natural habitat is getting tougher. Alien species accidentally or purposefully introduced into the Nordic Countries by man can become problematic and compete with our native species for resources, and even take over their territories.

Hunting, trapping, fishing and gathering directly affect the populations of many species. Other species' numbers are meanwhile dwindling due to various kinds of disturbance, persecution, and accidental deaths caused by traffic, power lines or wind turbines. In Greenland, the greatest challenge in terms of protecting species is to define and achieve sustainable levels of exploitation, since the populations of many species have long been overexploited. Climatic warming already represents a significant threat to Greenland's natural ecosystems and species. 
The ongoing climate change that has resulted from rapid economic growth and development will alter habitats and shift their distributions. Some habitats are even likely to vanish altogether from the Nordic region, together with their associated species. This is particularly true for arctic and alpine habitats and species. Climate change additionally compounds all the other threats facing biodiversity. Indirect impacts on biodiversity also arise due to pollution and its consequences such as acidification and eutrophication.

Naturally diverse ecosystems have lost out where developments have led to significant land use changes. In the Nordic Countries there are still almost untouched natural settings worth preserving, even though increasingly intensive economic activities and consumption patterns today affect even the most remote areas.

\subsection{Changing habitats}

Biodiversity has clearly been declining in the Nordic Countries, as elsewhere, but some positive trends are also evident here. Habitats that were previously spoilt are gradually being restored and rehabilitated, enabling species to return to their former haunts.

Natural environments have been shrinking all around the Nordic Countries as human populations have increased and our settlements have expanded. The consequent fragmentation of species-rich natural ecosystems and landscapes is still continuing, with roads and other structures breaking up many of the last remaining extensive natural areas. The most radical and visible land use changes have occurred as supposedly unproductive natural environments such as mires and wetlands have been converted to farmland, commercially managed forest or peat extraction sites. Sensitive species found in wild and unspoilt areas are increasingly suffering from disturbance, as off-road vehicles and nature tourism become more popular.

Agriculture has become more intensive in the Nordic region, and many relatively unproductive areas of former farmland are today no longer cultivated or grazed. This has led to the loss of biotopes created by traditional farming practices, and their associated species. Farmlands today tend to consist of large, uniform, chemically fertilised and mechanically worked fields with concealed drainage. Features that used to add variety to agricultural landscapes, such as wooded patches, ditches and grassy verges, have vanished.

Heaths, meadows, pastures and other species-rich traditional agricultural biotopes are the most seriously threatened habitats in Denmark, Sweden, Norway and Finland. Such habitats can easily become overgrown if they are no longer mown or grazed regularly. Overgrowth is accelerated by atmospheric nitrogen deposition. Many plant and insect 
species depend on such habitats, however, and such species have widely become endangered as their habitats have deteriorated or vanished. Thankfully we are now increasingly aware of the need to protect such biotopes, and restoration and management schemes have been initiated.

Finland's forests have been increasing in extent, but this is mainly due to peatland drainage schemes and afforestation. The resultant forests are unnaturally uniform, and cannot replace natural forest. This trend has also impoverished naturally diverse mire habitats. In recent years, however, forestry methods have become less ecologically disruptive, and cooperation between forestry and nature conservationists is improving. Foresters now consider the diverse features of forests during their work for instance by leaving dead trees in forests to benefit the many threatened forest species that depend on decaying wood. Forests aged more than 140 years are today more widespread than previously in Norway and Sweden, but still declining in Finland. In Denmark and Iceland the total areas of forest have increased, which could benefit biodiversity as a whole in these countries.

The total areas of mire habitats are still declining, even though there are few new ditching and wetland drainage schemes today. In many former mires used today for commercial forestry, drainage ditches are still re-excavated to maintain productivity. Conversely certain other mire habitats are instead being restored to their natural state, though these areas tend to be very small.

The acidification and contamination of water courses have declined in recent years thanks to reductions in emissions. In Norway and Sweden acidified rivers have been limed, and salmon (Salmo salar) have returned to some of their former spawning rivers. Intensified shipping and the consequently rising risk of oil pollution remain a major threat, particularly in the Baltic. Eutrophication continues, but restoration has helped many lakes to recover. The Baltic Sea is still suffering, and its sandy shores are widely becoming overgrown due to eutrophication. Invasive Japanese roses (Rosa rugosa) already cover many areas that used to consist of open dunes and shores. The total areas of shore meadow and dune habitats in Denmark have declined considerably. Shores are also still being developed widely.

Climatic warming could radically reshape natural habitats throughout in the Nordic region, with detrimental effects on their biodiversity. Such trends are hard to predict, but some consequences are already becoming evident. In the far north, the permafrost cores of palsas are melting, and if no new palsas form our unique palsa mires could soon vanish from Northern Europe. Ice sheets and glaciers are also shrinking, and the loss of permanent sea ice could be fateful for arctic species including polar bears (Ursus maritimus). Arctic fell habitats will also change, as tree lines shift northwards and higher up in the fells, leaving less space for fell species. These sensitive habitats are today also widely suffering from excessive grazing. 
Protected areas have been widely established around the Nordic Countries, and the total areas of land and water under protection are increasing. The emphasis today is on enhancing the representativeness of protected areas, with the goal of protecting at least $10 \%$ of each of the habitat types found in each country. Conflicts between nature conservation and economically beneficial commercial activities are still problematic. The Nordic Countries must take special international responsibility for the preservation of biotopes found exclusively or largely within our region.

\subsection{Many species dependent on conservation measures}

Due to all of the threats described above, many species are becoming more threatened at an alarming rate. The greatest threats are related to our economic activities and the consequent land use changes. Some species have thankfully been saved from the brink of extinction. But there is a need for more Nordic conservation success stories like the earlier recoveries of white-tailed eagles (Haliaeetus albicilla) and Saimaa ringed seals (Phoca hispida saimensis) from their population lows. New threats are appearing as others recede. White-tailed eagles and other birds of prey are today increasingly threatened by wind turbines and power lines, while Saimaa ringed seals are still at risk due to fishing nets and the impacts of climatic warming on the lake ice on which they build their snowy winter lairs. Climate change was not included among the threat factors considered in the most recent red list evaluations conducted in the Nordic Countries, but today it is already seen as a growing threat to biodiversity.

Baltic grey seal (Halichoerus grypys) and ringed seal (Phoca hispida baltica) populations have been increasing, but milder winters are also problematic for these seals, which similarly raise their pups in snowy lairs built on the frozen sea. During mild winters these dens can easily collapse before pups are ready to leave them. This is particularly a serious problem for the critically endangered Saimaa ringed seals in Finland. Today's larger marine seal populations have resulted in conflicts with fisheries, since the seals take fish from nets.

Overfishing is still a threat to many fish stocks, even though quotas have been set and fishing equipment improved, partly to limit by-catches. Cod stocks (Gadus morhua) in the Northeast Atlantic have been overexploited, and they have also suffered due to fluctuations in the stocks of their prey species herring (Clupea harengus harengus) and capelin (Mallotus villosus). Herring stocks in the Northeast Atlantic collapsed to the brink of extinction in the early 1970s, when no mature fish were left in the sea; but international action eventually helped stocks to recover. Cod and herring (Clupea harengus membras) stocks in the Baltic also need to be managed internationally. 
Many farmland and marshland birds have been declining in the Nordic region. Bramblings (Fringilla montifringilla) have been decreasing alarmingly in arctic mountain birch woodlands, especially in Sweden. Typical forest birds like the capercaillie (Tetrao urogallus) have also become scarce. At the same time barnacle geese (Branta leucopsis) have been proliferating in urban parks, and cormorants (Phalacrocorax carbo) have increased their numbers at sea. As the climate changes, the ranges of Europe's breeding birds may shift northeastwards by hundreds of kilometres. Migrating birds can more easily adapt to changing conditions than many other animal species, thanks to their mobility and warmbloodedness. They are able to adjust their migration according to temperature and growing season, to help them find favourable conditions and food supplies. Some bird species are already migrating earlier in the spring, and some have delayed their autumn departures. Species can shift their ranges northwards into new breeding areas - at least until they reach the shores of the Arctic Ocean. Arctic and alpine species are becoming endangered, as the total areas of suitable habitat shrink.

Amphibians are suffering from diseases and unfavourable changes in their habitat induced by climate change. In some localities their habitats have been restored and new artificial ponds have been built to make up for the loss of their natural spawning ponds, however, and such efforts have been reflected in considerable increases in their local populations. Conservationists' actions have already enabled the European tree frog (Hyla arborea) to be removed from Denmark's Red List, and there is increasing awareness of the need to protect other amphibians, such as great crested newts (Triturus cristatus).

The Nordic Countries' large carnivores - bears (Ursus arctos), wolves (Canis lupus), wolverines (Gulo gulo) and lynxes (Lynx lynx) - originally lived in harmony with the region's human hunters. But when people moved deeper into the predators' hunting grounds in search of game, large carnivores started to prey on the reindeer (Rangifer tarandus tarandus), livestock and dogs they found around human settlements, and conflicts inevitably arose. Only when these animals had been virtually hunted and persecuted into extinction in the Nordic region did people realise that they form a vital part of Nordic nature, and should therefore be preserved. The large carnivores are all protected today, but their populations are still managed using measures including controlled hunting. Their persecution has declined, but they are still feared, and not tolerated in the vicinity of human settlements.

In spite of all efforts to protect and monitor them, arctic foxes (Alopex lagopus) are no longer thriving in northernmost Fennoscandia. Their decline is thought to be indirectly caused by climate change, which has enabled red foxes (Vulpes vulpes) to spread northwards into regions where they have out-competed their arctic relatives and taken over their 
territories. Arctic foxes have fared better on the islands of the North Atlantic, where there are no competing red foxes.

Among domesticated animals and plants, local Nordic landrace breeds and crop varieties have widely declined and become endangered as farming has intensified and become more global. Now aware of this problem, the Nordic Countries have set up the Nordic Genetic Resource Center NordGen to safeguard the genetic diversity of Nordic landrace livestock breeds and crop varieties. Fortunately, many people willingly contribute to this valuable work.

Problems associated with invasive alien species have now been widely acknowledged, and strategies and action plans are being drawn up by all of the Nordic Countries. Such problems have also been increasingly publicized, and public interest in combating the spread of harmful alien species has increased. Such issues can nevertheless be problematic where people oppose the eradication of attractive invasive species such as lupins (Lupinus polyphyllus) or rabbits (Oryctolagus cuniculus), even if they do not naturally belong in Nordic environments.

\subsection{Opportunities to save threatened species}

It has proven impossible to halt biodiversity loss by 2010. The task of conserving biodiversity is unending. Before new goals and interim targets are set, we should carefully consider which factors need to be taken into account. In the Nordic Countries this work has already begun. At a symposium hosted by the Nordic Council of Ministers in Trondheim, Norway in October 2009, about 80 participants from all of the Nordic Countries focused on the current state of biodiversity and prospects for the future. The symposium's conclusions constitute a basis for the establishment of future biodiversity policies and practices in all of the Nordic Countries. They will also form a basis for the Nordic region's contributions in European and global contexts.

Information must be the basis of all policies. We need information about nature, biotopes, species, and their natural processes and functions. Research and monitoring work can provide us with new information to help identify vulnerable species and biotopes in need of protection. Such work is particularly needed for species groups that are not well known to science. Data on changes in species' populations and habitats needs to be effectively compiled and stored in regularly updated databanks. It is vital to collaborate internationally on the planning of such monitoring and information work, to ensure that the resultant data is comparable. Well planned and managed databanks can be used to meet regular reporting obligations related to national policies, EU level commitments and the UN Convention on Biological Diversity. 
To facilitate evaluations of species' statuses, the IUCN has issued classification guidelines that enable species' statuses to be evaluated at various geographical levels. Red Lists evaluating the statuses of species are published by all of the Nordic Countries in accordance with the IUCN guidelines. So far only Finland has assessed the statuses of habitat types, though such an evaluation is under way in Norway. The web-based NOBANIS databank on invasive alien species has been produced through a Nordic initiative, and it now includes data from all of the Nordic Countries, ten other European countries and European Russia. Norway has already a Black List of undesirable invasive alien species.

Sufficient information on species, biotopes and their statuses will enable conservationists to find ways to ensure their favourable conservation statuses. The main starting point for protecting species is the protection of their habitat. This involves enacting legislation, issuing recommenda-tions, and drawing up conservation programmes, strategies and action plans. Species can be protected through population management plans, hunting restrictions, managed introductions, breeding programmes and other measures to ensure their populations are viable. For many habitat types the situation has already become acute, where such habitats have already widely deteriorated or been destroyed. Suitable solutions in such cases include habitat management, rehabilitation and restoration schemes.

One significant development in thinking on nature conservation is the ecosystem approach, which emphasises the need to preserve the structures and functions of entire ecosystems. In this context it is important to raise awareness of the vital services that ecosystems provide for us and the fact that these services are vulnerable and limited. Biodiversity includes elements such as ecosystem services that cannot easily be given financial values. One example of such an ecosystem service is the pollination services insects provide for plants including our vital food crops. Almost all seed plants need to be pollinated to produce seeds, fruits and future plant generations. Oil-producing plants and the plants we feed to our livestock also need to be pollinated. Today attempts are increasingly being made to calculate economic values for ecosystem services and the costs of habitat change, so that their importance can be duly considered in relation to other socio-economic activities that may affect them. The economic benefits of investments made primarily for the sake of nature conservation are also increasingly being measured.

No protective measures will be sufficient if the threats to habitats and their species are permanent. The best way to preserve species is to minimise or eliminate the threats they face. The most serious threat to biodiversity is land use changes. Land use planners working right down to municipal level must be provided with the right expertise on nature conservation issues to enable them to account for biodiversity impacts in their decision-making on all land use issues. Collaboration between different actors is particularly vital in combating climate change and the 
spread of invasive alien species. The media and schools play crucial roles in the related publicity and educational work. Information must be spread starting from grassroots level with children and local initiatives, but then reaching through society as a whole, especially focusing on the need for decision-makers to be well informed.

The year 2010 can come to represent a turning point in the conservation of biodiversity, as new targets take shape. Instead of issuing too many prohibitions and alarmist messages, we must build positive and constructive approaches to conservation in various contexts. It is crucial to get all levels of society involved in the task of conserving biodiversity - from schoolchildren and their families, to decision-makers at the highest level. The key challenge facing governments and businesses is to commit sufficient resources to preserve biodiversity during the theme year of 2010 and into the future.

\subsection{References for the summary}

Boertmann, David. 2007. Grønlands Rødliste 2007. Greenland red list. Grønlands Hjemmestyre, Direktoratet for Miljø og Natur.

Gärdenfors U. (ed.). 2005. Rödlistade arter i Sverige 2005 - The 2005 Red List of Swedish Species.

ArtDatabanken, SLU, Uppsala.

Hallanaro, Eeva-Liisa \& Pylvänäinen, Marja. 2002. Nature in Northern Europe - Biodiversity in a changing environment. Nord 2001:13, Nordic Council of Ministers, Copenhagen.

Kålås, J.A., Viken, Å. \& Bakken, T. (eds.). 2006. Norsk Rødliste 2006 2006 Norwegian Red List.

Artsdatabanken, Norge.

Nordic nature - trends towards 2010 project: Fact sheets on the internet www.environment.fi/nordicnature

Normander Bo et.al. 2009. State of biodiversity in the Nordic Countries. An assessment of progress towards achieving the target of halting biodiversity loss by 2010 . TemaNord 2009:509. Nordic Council of Ministers, Copenhagen 2008.
Raunio, A., Schulman, A. \& Kontula, T. (eds.). 2008. Suomen luontotyyppien uhanalaisuus - Osa 1. Tulokset ja arvioinnin perusteet Assessment of threatened habitat types in Finland - Part I: Results and basis for assessment. - Suomen ympäristö 8:2008.

Raunio, A., Schulman, A. \& Kontula, T. (eds.). 2008. Suomen luontotyyppien uhanalaisuus - Osa 2. Luontotyyppien kuvaukset Assessment of threatened habitat types in Finland - Part II: Habitat type descriptions.

- Suomen ympäristö 8:2008.

Rassi, P., Alanen, A., Kanerva, T. \& Mannerkoski, I. (eds.). 2001. Suomen lajien uhanalaisuus 2000 - The 2000 Red List of Finnish species. Ympäristöministeriö \& Suomen ympäristökeskus, Helsinki.

Stoltze, M. \& Pihl, S. (eds.). 1998. Rødliste 1997 over planter og dyr i Danmark. The Danish Red List 1997. Miljø- og Energiministeriet, Danmarks Miljø-undersøgelser og Skov- og Naturstyrelsen. 


\section{Fact sheets}

- Countdown 2010

- The UN Convention on Biological Diversity

- Ecosystem services

- Cod and herring stocks in the Northeast Atlantic

- Baltic cod and herring stocks - changing interactions between predators and prey

- The triumphant return of the white-tailed eagle

- The polar bear - top arctic predator dependent on sea ice

- The unique Nordic landraces

- Birds reacting to climate change

- Alien Species in the Nordic Countries

- Can Nordic amphibians be saved?

- Towards sustainable reindeer and sheep grazing in the Nordic Countries

- Nordic inland waters successfully restored

- Local contributions to halt the loss of biodiversity

- Traditional agricultural biotopes vanishing in the Nordic Countries

- Europe's national parks celebrate a century of conservation

- Threats to biodiversity in the Nordic Countries

- Ecologically diverse sandy seashores under threat

- Postcards highlight local responsibility for threatened species 


\section{Countdown 2010}

Species are becoming extinct around the world today at an alarming rate. The consequent loss of biodiversity is widely blamed on man, so it is clearly our responsibility to act to reverse this trend.

The aim of halting the loss of biodiversity by 2010 was first mentioned in the EU's sustainable development strategy in 2001. In the following year, the $6^{\text {th }}$ Conference of Parties to the UN Convention on Biological Diversity defined an objective to significantly slow the loss of global biodiversity by 2010 . Similar goals have subsequently been included in many more environmental agreements and schemes, approved by the UN General Assembly, and incorporated in the UN's Millennium Development Goals.

In 2004 the World Conservation Union (IUCN) and the EU Commission jointly launched the Countdown 2010 initiative to help realise these goals. Countdown 2010, which is now global in scope, aims to activate many different stakeholders to work to preserve biodiversity. The Countdown 2010 Declaration may be signed by all kinds of organisations, from local and national authorities and institutes to NGOs and businesses. The progress made by signatory countries and organisations towards the declaration's goals is monitored annually.

The Countdown 2010 initiative defines seven key steps that can be taken to help save biodiversity:

1. At least $10 \%$ of all ecosystem types should be under protection to maintain nature and natural landscapes.

2. Farming practices should consider biodiversity, for instance by improving farmland diversity and reducing the usage of pesticides and fertilizers.

3. Fish stocks should be sustainably managed. Today $75 \%$ of all fisheries are over-exploited, and many species are already threatened with extinction.

4. Urban and rural construction and land use developments must give greater consideration to biodiversity. Today such developments are destroying the habitats of many species.

5. Climate change also affects habitats. Climate change should be combated and the species' chances of migrating or adapting to their new surroundings should be ensured.

6. Some alien species become invasive and may destroy local flora and fauna, so the spread of such species should be prevented.

7. Biodiversity is the foundation for sustainable development, so biodiversity concerns need to be integrated into all areas of policy-making.

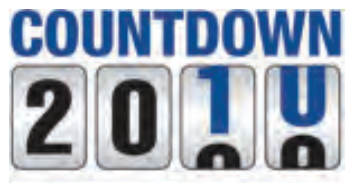

SAVE BIODIVERSITY

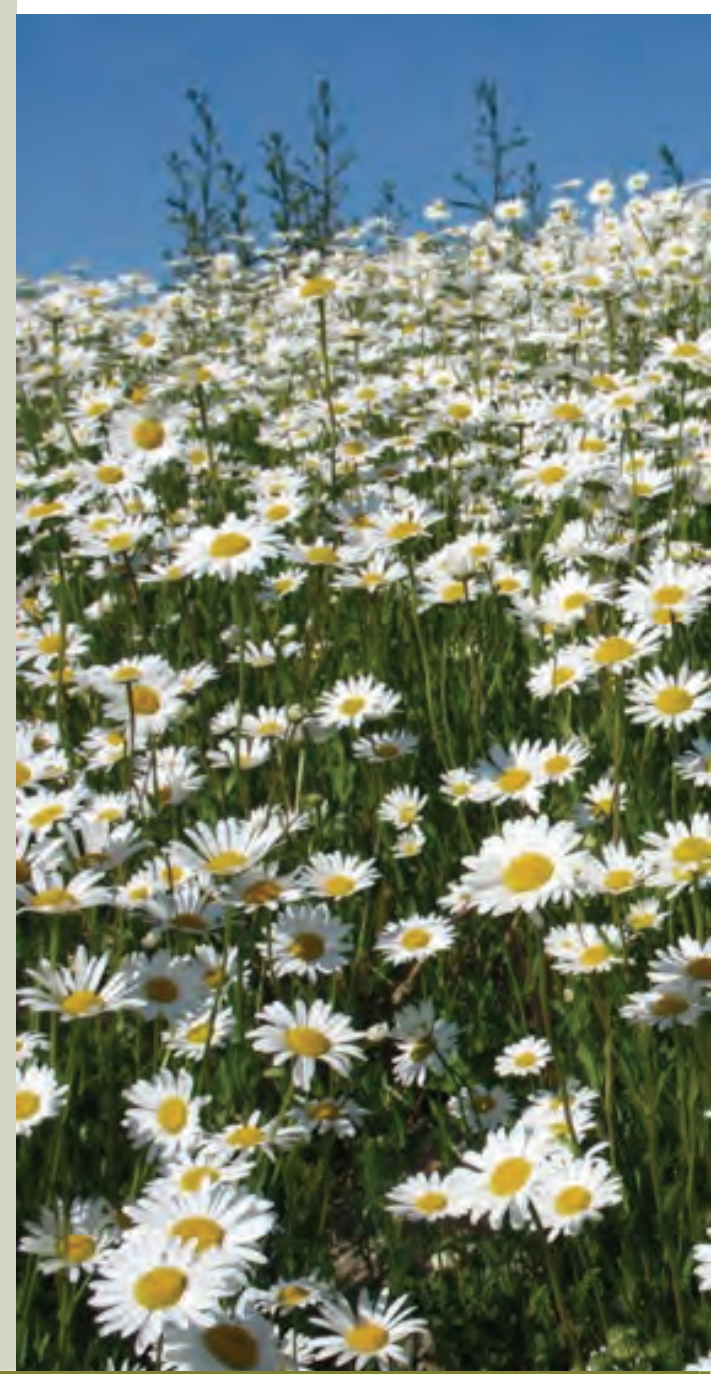


In Europe the goal of curbing the decline in biodiversity has been prioritised more highly than in other parts of the world, and the aim is to halt biodiversity loss by 2010 rather than just slow the trend. Europe's common goal is to work towards this target by implementing purposefully designed legislation and agreements, while also revising other EU policies to ensure that they help to reach the target.

Four of the Nordic Countries have signed the Countdown 2010 Declaration: Finland (2006), Sweden (2006), Norway (2007) and Denmark (2007). In addition to these countries' respective environment ministries, various local authorities, NGOs and businesses have also signed up. Iceland has not officially signed the declaration, but the 2010 target is nevertheless included in the current national government programme.

As part of the Countdown 2010 initiative Finland has held a competition for the best action to benefit biodiversity. The competition aims to publicise practical measures that have successfully slowed biodiversity loss. In 2006 the Countdown award was granted to the Public Works department of the City of Helsinki for their landscaping of a former landfill site in Vuosaari, where carefully planned plantings of cuttings from local plants have created suitable habitats for many other local species.

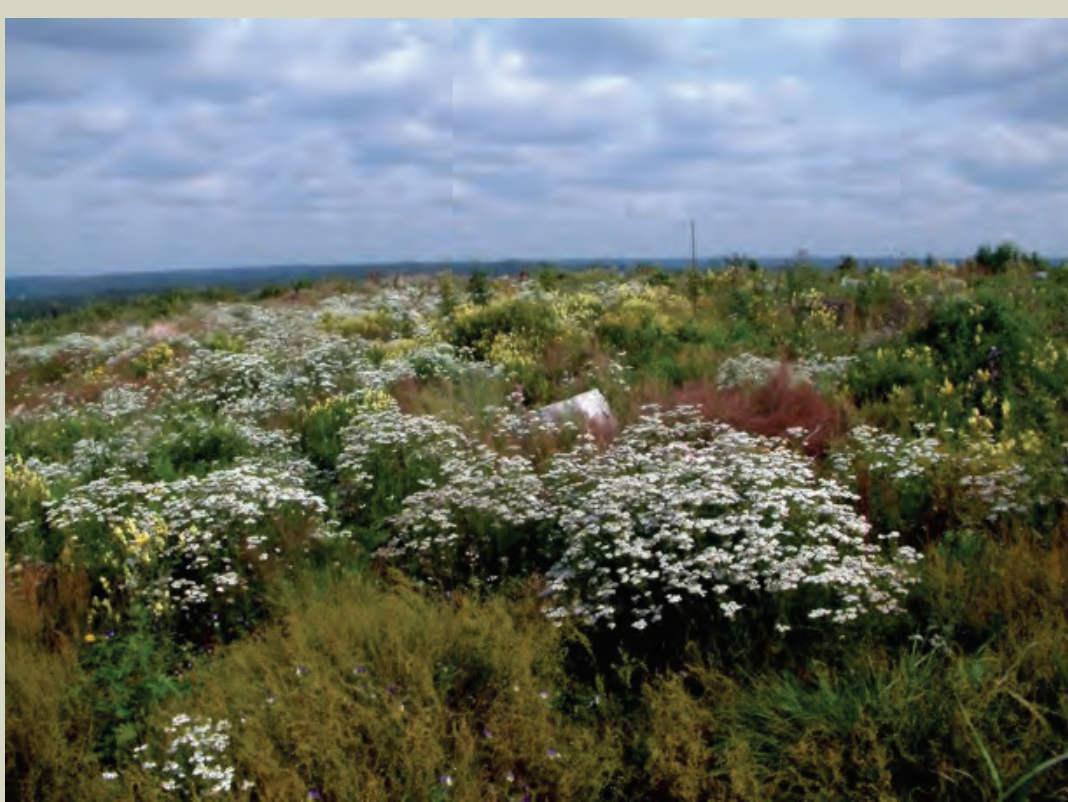

View over the landfill site in Vuosaari. Picture: Kristiina Pekkonen.

\section{Nordic signatories of the Countdown 2010 Declaration:}

Finland:

Ministry of the Environment

City of Vantaa

The Kosken kartano estate

\section{Sweden:}

Ministry of the Environment

Museum of Natural History

\section{Norway:}

Ministry of the Environment

City of Trondheim

\section{Denmark:}

Danish Entomological Society Danish Outdoor Council

Danish Ornithological Society Nordeco, NGO

Nepenthes, NGO
Sources: www.countdown2010.net,

www.cbd.int, the Finnish Countdown 2010 declarartion, the Norwegian Countdown 2010 declaration, www.environment.fi > International issues $>$ Global co-operation > World Conservation Union (IUCN) National Committee of Finland > Countdown 2010.

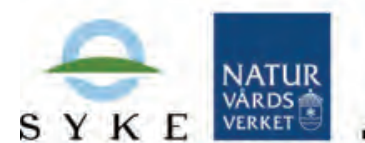

S Y K E

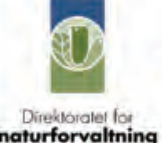

Datureklorale! for
MILJØ̈

By- og Landskabsstyrelsen
Direktoratet for Miljo og Natur umhervisstovan
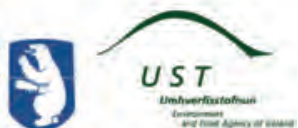


\section{The UN Convention on Biological Diversity}

The UN Convention on Biological Diversity (CBD) was adopted in Rio de Janeiro in 1992. At the 2002 World Summit on Sustainable Development in Johannesburg the heads of more than 150 states confirmed that the CBD is the most important tool for conserving biodiversity at global level.

So far 190 states are parties to the CBD, including all of the Nordic Countries.

\section{Biological diversity}

Biological diversity, or biodiversity for short, encompasses all the diversity of plants, animals and micro-organisms, as well as the variety of ecosystems and the genetic diversity within species.

The UN Millennium Ecosystem Assessment of 2005 indicated that people's actions over the last 50 years have changed the world's ecosystems more than at any previous stage of the history of humanity. Current species extinction rates are 50-100 times higher than natural levels. The most important factors behind these trends include habitat destruction, invasive alien species, the unsustainable use of natural resources, climate change and pollution. The UN report emphasises the vital importance of biodiversity for the continuing survival of humanity, and for our prosperity, well-being and enjoyment.

\section{The 2010 Biodiversity target}

At the 2002 World Summit on Sustainable Development the parties to the CBD resolved that a significant reduction should be achieved by 2010 in the rate of biodiversity loss as a consequence of human actions. The EU has decided on a more ambitious target, to halt the loss of biodiversity altogether.

\section{Aims and implementation of the convention}

The convention sees people as part of nature, and recognises their right to use natural resources while at the same time carefully monitoring the impacts of resource exploitation on ecosystems. The convention aims to conserve biodiversity, to ensure the sustainable use of natural resources, and to guarantee the equitable sharing of the benefits arising out of the utilisation of genetic resources.

Parties are obliged to draw up national strategies and action plans for the conservation and sustainable use of biodiversity, and report on their implementation of the CBD. Key obligations concern the establishment and maintenance of protected areas, the protection of threatened species and populations, and the monitoring of biodiversity. Protected areas should eventually comprise an extensive network covering $10 \%$ of the total area of each habitat type. This goal has not yet been realised for all habitats.

The rich countries are responsible for helping poor countries to implement the CBD through financial assistance and technology transfer. This obligation also applies to the Nordic Countries and their development co-operation partners.

The convention is put into practice through legislation and other policy instruments applied nationally or by international communities such as the EU.
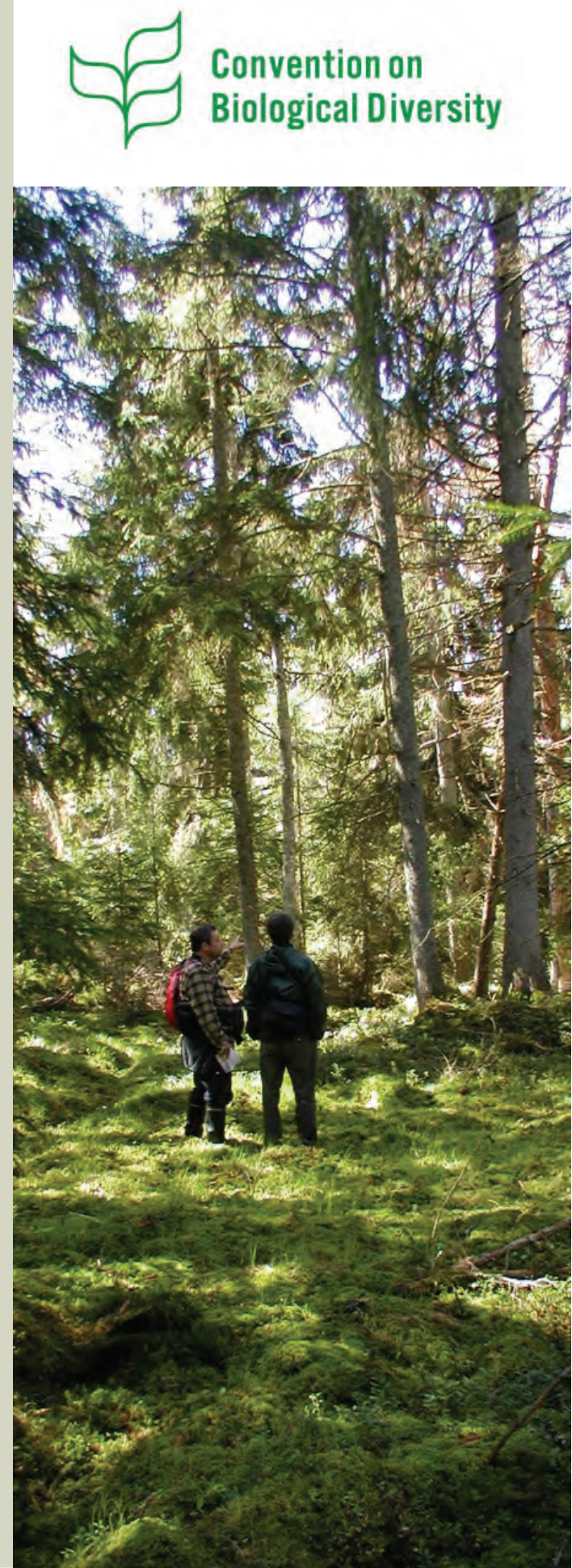


\section{Genetic resources and ecosystem services}

Genetic resources have great economic importance as raw materials in the fields of biotechnology, medicine, cosmetics, agriculture and food processing An estimated $40 \%$ of the global economy is based on biological products and the natural processes provided by the world's ecosystems for humanity known as ecosystem services.

The developing countries have the lion's share of the world's genetic resources, but the technology for their commercial exploitation is largely owned by the industrialised countries. The CBD urges that mechanisms should be devised to ensure that the benefits of the exploitation of genetic resources are shared equitably.

\section{Indigenous peoples and traditional knowledge}

The CBD has a special programme of work concerning the traditional knowledge, innovations and practices of indigenous and local communities. The convention stresses that indigenous peoples' traditional knowledge of biodiversity and ways to use it sustainably should be duly respected. The benefits of the use of this knowledge should also be shared equitably.

\section{Information and public awareness}

It is vital that people should understand the urgency of conserving biodiversity. The parties to the CBD have committed themselves to inform their citizens about the importance of species and habitats. Each country is obliged to set up a national Clearing-House Mechanism (CHM) for the dissemination of biodiversity data. Issues related to the conservation and sustainable use of biodiversity should also be incorporated into communications and educational programmes at all levels.

\section{Organisation of the convention}

The most important organisational bodies of the $\mathrm{CBD}$ are the Conference of the Parties, (COP), the CBD Secretariat, and the CBD's Subsidiary Body on Scientific, Technical and Technological Advice (SBSTTA). COP conferences are held every two years to decide on issues including possible changes to agreements and protocols, the implications of new scientific data, reporting processes, and other necessary development work.

\section{The Cartagena Protocol on Biosafety}

In January 2000 the parties to the CBD signed a supplementary agreement known as the Cartagena Protocol on Biosafety, concerning living modified organisms (LMOs). The Protocol aims to ensure adequate protection for the environment whenever LMOs are transferred over national borders or used internationally, in agriculture and food production, for instance.

\section{COP 9}

The 9th meeting of the Conference of Parties to the CBD is being held in Bonn 19-30 May 2008. COP 9 will focus on various issues related to the CBD, including the biodiversity of farmland and forest habitats, invasive alien species, the ecosystem approach, the development of incentives, the Global Strategy for Plant Conservation, progress towards the 2010 target and the Millennium Development Goals, and economic resources and mechanisms. Apart from these main issues also other topics are discussed. Interesting topics from a Nordic perspective include:

\section{- protected areas}

- biodiversity and climate change

- biodiversity of inland waters

- marine and coastal biodiversity

- island biodiversity

- communication, education and public awareness

\section{Nordic co-operation}

Under the leadership of the Nordic Council of Ministers, the Nordic Countries have jointly developed a Nordic Genetic Resource Strategy to enhance the conservation and sustainable use of genetic diversity in agriculture, forestry, fishing and food production. Such co-operation also helps to implement the CBD with regard to the availability of genetic resources and related rights.

All of the Nordic Countries are also involved in the North European and Baltic Network on Invasive Alien Species (NOBANIS). This collaborative project covers all terrestrial, marine and freshwater ecosystems. It has produced a database on ecosystems. It has produced a database on
invasive alien species, a list of related regulations, a database of related literature, and informative leaflets about several invasive alien species. The network also has close links with other regional and global networks and projects working to combat the harmful impacts of invasive alien species.

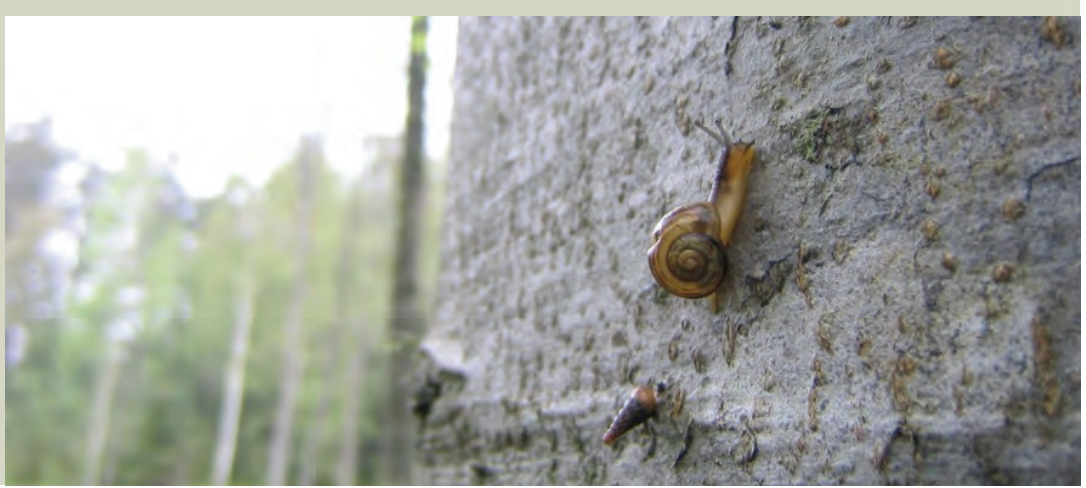

Sources:

- Convention on Biological Diversity (with annexes)

Concluded at Rio de Janeiro, 5th June 1992.

- Nordic Council of Ministers 2006: For a richer future 13 conventions on the natural and cultural environment. TemaNord 2006:565.

- Ulkoasiainministeriö 2007: Kansainväliset

ympäristösopimukset ja Suomen kehityspolitiikka 2007. (Finnish Ministry for Foreign Affairs 2007: International environmental agreements and Finland's development policies 2007.)

- Phillips, B. \& Jones, T. 2007: "Mountains to the sea" Implementation Framework for the Convention on

Biological Diversity's cross-cutting programmes of work. WWF.

- www.cbd.int

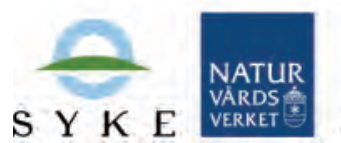

S Y K E

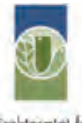

Direkdorale for
naturforvaltning

\section{MILJØMINISTERIET}

By-og Landskabsstyrelsen umhvorvisstovan
Grønlands Hjemmestyre 


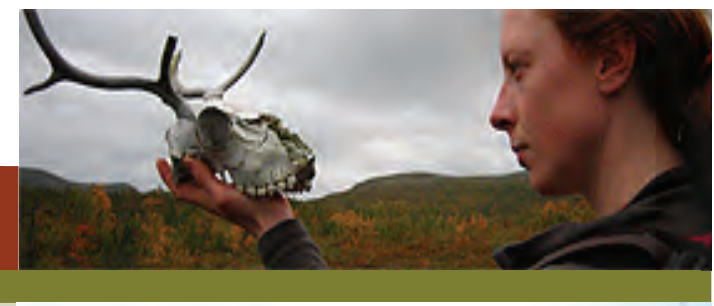

\section{Ecosystem services \\ - insurance for our future}

\section{Free services provided by nature}

People benefit from the many services provided by natural ecosystems, such as natural resources and various natural processes. These so called ecosystem services are vital and irreplaceable, since our livelihoods and our survival are based on the natural resources.

Ecosystem services can be grouped in four categories: goods, regulating services, supporting services and cultural services. Goods include vital organic and inorganic natural resources ranging from foods and clean air and water, to fuels and building materials. Cultural services include opportunities for outdoor recreation and the aesthetic benefits of natural environments. More complex regulating and supporting services include the pollination of crops and other plants, nutrient cycles, and the flood protection provided by wetlands. Such services are all vital in terms of food production and the preservation of the natural environment. Functioning ecosystems also maintain crucial nutrient cycles and the productivity of soils.

Ecosystem services are freely available in financial terms. In principle they exist to everyone's advantage, although in practice their benefits are shared unequally between people in different parts of the world. They are also sensitive, ultimately limited in scope, and dependent on our actions. If we pollute water, for instance, clean water will no longer be available, and if we exhaust farmland soils we will no longer be able to grow food crops. If we destroy the habitats of pollinating insects, our own food supply will be reduced as crop plants suffer. The great challenge facing us now is to make people more aware of the importance of such ecosystem services, by pointing out what will happen if they are lost or significantly weakened. The future of insect pollination is a crucial case in point.

\section{Pollination - a vital ecosystem service}

Einstein is said to have pointed out that man would only be able to survive for a few years if pollinating insects like bees suddenly died out. There is plenty of truth in this statement, even though some of our food plants can be pollinated in other ways. Plants may be self-pollinating, or pollinated by the wind, water or animals. In the Nordic Countries pollination by animals is most often the work of insects, although birds, bats and other mammals may also help. The most effective pollinating insects include bees, bumblebees, wasps, butterflies and other insect groups like hoverflies that fly from plant to plant in search of food. These humble creatures play an irreplaceable role in the production of fruits, berries.

People are dependent on pollination as a vital phase in the life cycle of seed plants. Almost all of our crops need to be pollinated before they can produce the fruits or seeds we and other animals use directly as food. Seeds are also necessary for the production of subsequent crop generations. The plants eaten by the animals we raise for their meat and milk also depend on pollination, as do the oil plants. The future survival of the many plants we use that are pollinated by insects will depend on our efforts to preserve their pollinators.

Without pollination our diet would lack fruits, berries and vegetables - all vital sources of vitamins and ingredients of our traditional dishes. Our farms and gardens would have no more orchards, berry bushes or vegetable plots. Berry-bearing plants would also vanish from our forests, eliminating this free source of food and an important resource promoting outdoor recreation. The domesticated bees kept in farms and gardens pollinate the crop plants and produce honey that we use.

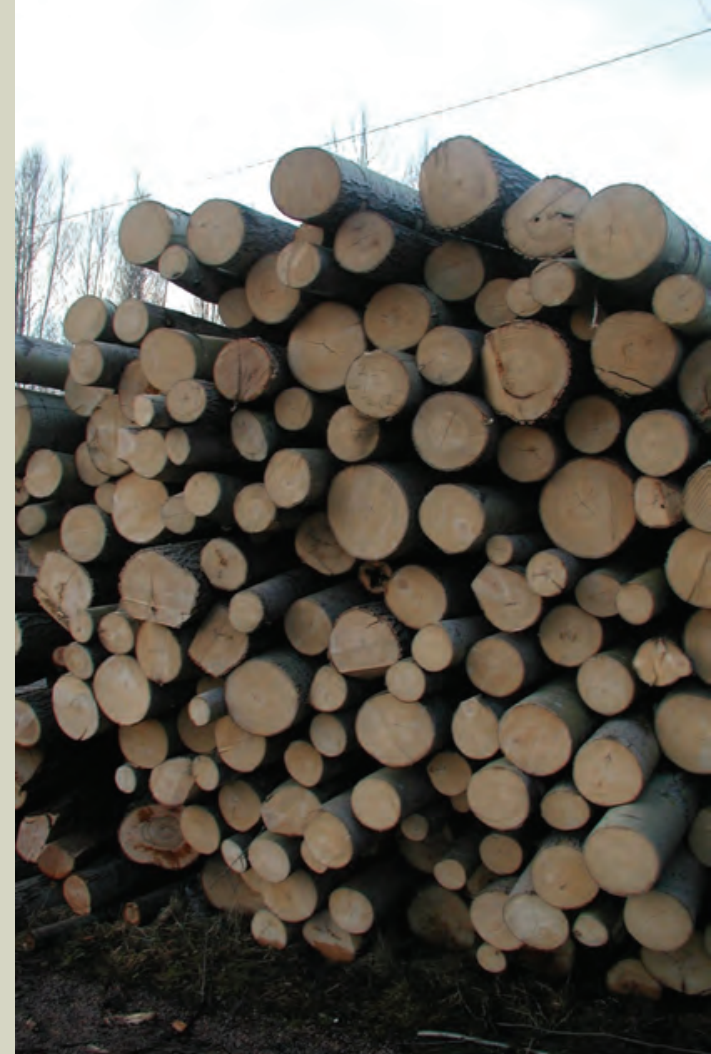

From forests we get raw materials for several kinds of products and also fuel. In addition to these products forests provide cultural services in the form of landscapes and recreation. Because of the many different ecosystem services the forests provide they should be used sustainably.

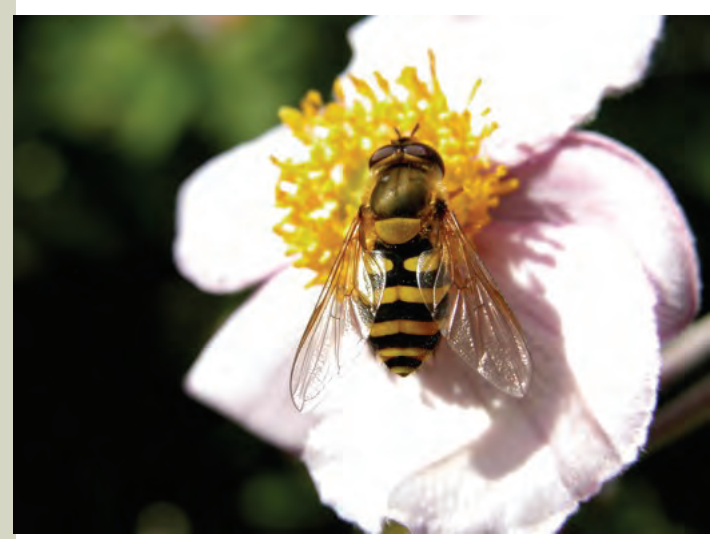

The common banded hoverfly (Syrphus ribesii) is a common and important pollinator. Picture: J. C. Schou. 
Any decline in insect pollinators can reduce harvests, since the wind alone cannot provide adequate pollination. Without insect pollinators our diets would be limited to vegetatively propagated root crops like potatoes, self-pollinating cereals like wheat, oats, barley, maize and rice or wind-pollinated cereals such as rye. Milk- and meat-producing livestock could survive on grasses, which are wind-pollinated, but they would no longer be able to graze on diverse insect-pollinated meadows. Celiac sufferers might struggle to eat well without the option of buckwheat. The genetic diversity of plants producing fruits and berries would inevitably decline without cross-pollination, making them more vulnerable to plant diseases, insect pests and climate change, as their adaptability decreases.

\section{Pollination providers under threat}

In the Nordic region pollinating insects are threatened by the impacts of changing land use practices, particularly the overgrowth of meadows and the fragmentation of areas of suitable habitat. The early mowing of meadows before flowers bloom, and the intensive management of roadside verges also reduce their food supply, leaving them with few alternative sources of nutrition. It is also becoming harder for many insects to find suitable holes for nesting.

Organic farms particularly need pollinators, since their naturally diverse meadows have many nectar flowers. This means that we can only get organic meat and dairy products onto our tables if insects continue to pollinate pastures and fodder plants. Organic farming also benefits pollinators by using less pesticides. Many pesticides harm useful pollinating insects as well as the insect pests they target. Most of our threatened pollinating insect species are associated with traditional farmland habitats.

New research findings have recently been published on the impacts on pollinators of air pollution. Insects find flowers by scent as well as by sight, but tropospheric ozone and other forms of pollution caused by our industries and traffic can break down the aromatic hydrocarbons produced by flowers to attract pollinators. These factors make it harder for insects to find plants, and their overall condition is affected when having to wander in search for the flowers. Such problems are worst in badly polluted and fragmented areas.

Climate change could well bring new pollinator species to the Nordic region, leading to competition with existing native species. In summer 2007 an unusually large swarm of median wasps (Dolichovespula media) was observed in Finland. Formerly rare European hornets (Vespa crabro) have also become more common in Finland lately.

In various parts of the world, notably the USA, colonies of domesticated bees have been dying off for unknown reasons in recent years. Significant declines among wild pollinating insects such as bees and hoverflies have meanwhile been noted in the British Isles and Holland, where the plants they feed on have also been decreasing. It is difficult to prove the direction of any causal link between these trends, but this worrying phenomenon needs to be studied more widely. It is quite likely that similar declines are under way elsewhere including the Nordic Countries. Finland has the second summer with less bees and bumblebees than in normal summers. The reason for these declines aren't known for certain, but the insects wintered poorly after the unfavourable summer last year. The warm winter and parasites may also play a part.

Pollinating insects provide a double ecosystem service by supporting the production of vital natural foodstuffs, while also boosting the growth of cultivated fruits and wild berries, and thereby providing a cultural service. Like other ecosystem services, pollination provides a freely available service both for people, and for the natural environment as a whole.

It is very difficult to estimate the value of ecosystem services in financial terms, but such valuations could still be necessary as the only way to ensure they are not neglected in assessments of the environmental benefits and disadvantages of socio-economic developments.

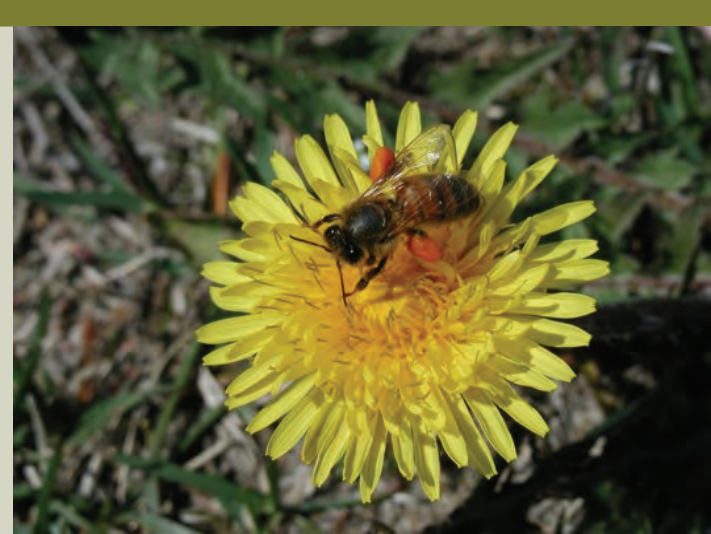

A honeybee (Apis mellifera) collecting pollen in the pollen sacs on its legs. Plants need pollination for their reproduction. Successful pollination significantly increases the size of seeds, berries and fruits. The importance of honeybees in pollination has increased when natural pollinators have decreased. Honeybees aren't as effective pollinators as bumblebees, but their pollination efficiency is based on large colonies. Picture: J. C. Schou.

\section{Ecosystem approaches for all activities}

The ecosystem approach is a concept devised in the context of the UN Convention on Biological Diversity to emphasise that all natural elements and processes within ecosystems should be duly considered in the planning of land use. One key principle is that the environment should only be exploited sustainably. The ecosystem approach has been created to establish a form of conservation of natural habitats and organisms that also considers humans and human activities. A guiding principle is that the vital structures and functions of ecosystems must be preserved in order to guarantee the future availability of ecosystem services to support our own well-being

\section{References:}

- The Green Lane website of Environment Canada - Q. S. McFrederick, J. C. Kathilankal, J. D. Fuentes. 2008. Air pollution modifies floral scent trails. Atmospheric Environment 42:2336-2348.

- R. Leinonen \& J. Itämies 2008: Työvoimapulaa pölytyshommissa. - NATURA 2/2008, biologian ja maantieteen opettajien liiton julkaisu, 45. vuosikerta, ss. 22-24. (Employment shortage in pollination, article in Finnish)

- Luonnontieteellinen keskusmuseo, Helsingin yliopisto, tiedote 11.6.2007 "Suurikokoisten pensasampiaisten vaellus vyöryi yli Suomen". (Finnish Museum of Natural History press release 11.6.2007 on the recent spread of median wasps through Finland)

- J. C. Biesmeijer, S. P. M. Roberts, M. Reemer, R. Ohlemüller, M. Edwards, T. Peeters, A. P. Scahffers, S. G. Potts, R. Kleukers, C. D. Thomas, J. Settele, W. E. Kunin. 2006. Parallel Declines in Pollinators and Insect-Pollinated Plants in Britain and the Netherlands. Science Vol. 313, 2 July 2006.

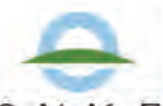

S $Y K E$

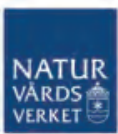

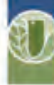

Direktoralei for

\section{MILJØMINISTERIET}

By-og Landskabsstyrelsen umhvorvisstovan Grønlands
Hjemmestyre Hjemmestyre
UST

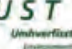


norden

Nordic Council of Ministers

NORDIC NATURE - TRENDS TOWARDS 2010

\section{Cod and herring stocks in the}

\section{Northeast Atlantic}

The marine areas within the Nordic Countries include the Greenland Sea, the Barents Sea, the Norwegian Sea, the North Sea and the brackish waters of the Baltic Sea. A couple of hundred fish species live in the Nordic waters of the Atlantic Ocean, while the Baltic is home to about 100 fish species adapted to its low salinity levels. The fish populations are quite distinct on each side of the narrow Danish Straits.

When traditional methods were used, fishing and fish stocks remained at sustainable levels. Commercial fishing became more intensive and more specialised in the $19^{\text {th }}$ century when new techniques began to be used. By the mid $20^{\text {th }}$ century many stocks could no longer sustain the excessive fishing pressure, and they collapsed. Certain stocks such as Norwegian springspawning herring were fished to the brink of extinction.

The region's countries must define common fishing policies to ensure that fishing is biologically, ecologically and economically sustainable, while also guaranteeing the safe supply of food for local communities. In earlier days the intensity of fishing was regulated by the abundance of fish stocks, but today fishing levels are regulated through quotas, or through temporary fishing bans in certain waters. However, the quotas set to limit fishing are often higher than the levels recommended by fisheries scientists - and they are also sometimes exceeded in practice.

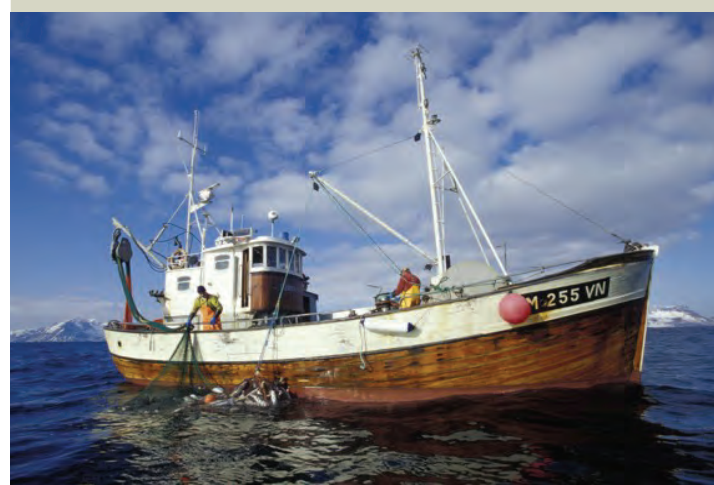

Fishermen collecting the catch. Picture: Samfoto.
The most commercially important species for

Nordic marine fisheries are cod (Gadus morhua), herring (Clupea harengus) and capelin (Mallotus villosus). Herring and capelin are the most important prey for Atlantic cod, so the survival of their stocks is also vital for cod. The Nordic Countries have long considered the relationships between these species when regulating fishing in marine waters. There is plenty of information about cod, herring and capelin, and their stocks are closely monitored. All three species are able to reproduce effectively enough to enable their recovery, as long as conditions in their spawning habitats remain favourable.

\section{Action needed to help cod stocks recover}

The cod is the most commercially important fish species both in the Nordic Countries and worldwide. Cod are bottom-dwellers, feeding on benthic animals and deepwater fish. They will also eat other cod when their prey species are in short supply. Cod stocks have fluctuated dramatically over the last 50 years.

The most important cod stocks in Nordic waters live in the Arctic waters of the NE Atlantic, where they live in the Barents Sea and mainly spawn off the coast of Northern Norway. Other Nordic oceanic cod stocks live in waters of Greenland, Iceland, the Faroe Islands and the North Sea. Several smaller populations live along the Norwegian coast. The coastal population found north of Latitude $62^{\circ} \mathrm{N}$ was listed as threatened in 2006, due to its poor state and ineffective fishing controls.

Icelandic cod catches in the 1970 s used to be twice their levels today. Stocks were more plentiful in those days overall, but spawning stocks were in fact smaller than they are thought to be today. Fishing was first restricted in the late

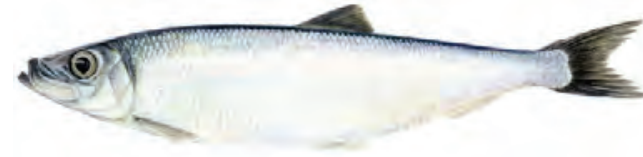

Herring (Clupea harengus). Picture: Jón Baldur Hliðberg

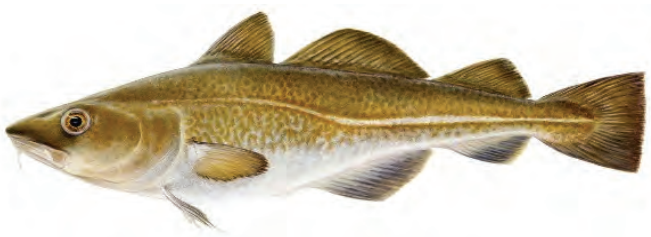

Cod (Gadus morhua). Picture: Jón Baldur Hliðberg

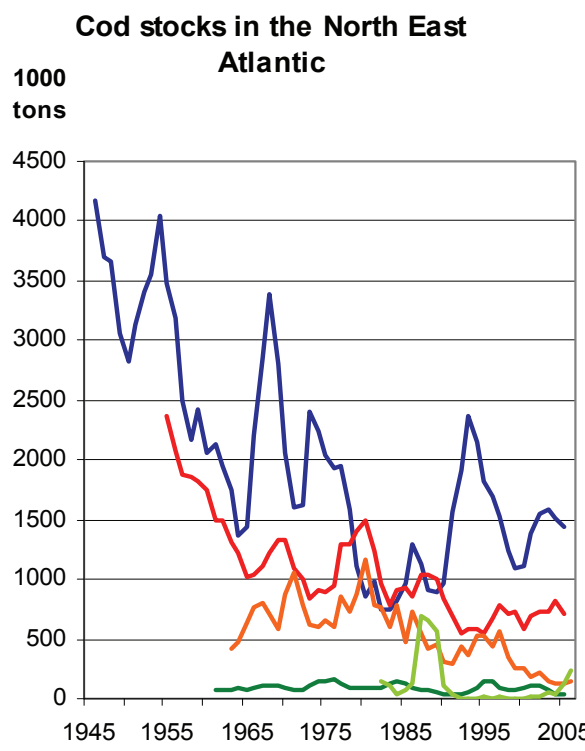

\footnotetext{
NE Arctic (ICES I,II)

_ Faroe Islands (ICES Vb1)

Iceland (ICES Va)

North Sea (ICES Na, Nb, Nc, VIld, Illa)

Greenland (ICES XIV, NAFO 1a-1f)
}

NE Atlantic cod stocks have suffered from both overfishing, and food shortages, as stocks of their prey species herring and capelin have fluctuated. According to ICES, the reproductive capacity of stocks around the Faroe Islands has been weakened, and current fishing levels are unsustainable. ICES has consequently called for a recovery plan to protect these stocks. The figure shows the total stock biomass of cod. Source: ICES Stock Assessment Summaries 2006, NAFO 2007. 
1970s, but these measures were insufficient. Cod stocks only began to recover in the mid 1990s thanks to stricter controls, and they will remain low for many years, since reproduction rates have been low.

NE Arctic cod stocks endured similar problems in the 1970s. Young cod were intensively trawled, and stocks collapsed due to overfishing. Quotas were set many times higher than the levels recommended by fisheries biologists. Cod also suffered from a shortage of food, as capelin stocks fluctuated dramatically, giving a clear example of how population variations or overfishing of one species can affect other species. Reductions of quotas in the 1990s and increases in capelin stocks eventually contributed to a recovery in NE Arctic cod stocks. Their numbers are still low today, however, as fisheries still catch too large a proportion of the stocks every year.

Two cod stocks live in Greenlandic waters, one along the west coast, and another in more open waters both east and west of Greenland. The coastal stock consists of several smaller populations whose numbers tend to remain fairly stable, though they may occasionally be reinforced from stocks in more open waters when these stocks are numerous. The stocks in the open seas fared well into the 1960s, but to the west of Greenland they collapsed in the late 1960s due to overfishing and a chilling in the climate. In the 1980 s they were replenished from Icelandic stocks, and continued recovering until cod started to return to Icelandic waters to spawn. Subsequently these western stocks have not been fished at all, and the eastern stock has only been fished very sparingly. Twice in recent years cod have come from Icelandic waters to spawn west of Greenland, and with careful management it should be possible to restore a spawning population in these waters. There is also known to be a spawning population east of Greenland, where fishing has already been permitted again.

The North Sea, on the margins of the Atlantic Ocean, has one of the world's most productive marine fisheries. North Sea cod stocks have never before been fished to such low levels as in recent years. The fish spawned over the last four years have been so limited in number that it is hard to envisage North Sea cod stocks recovering in the near future. The whole stock is so unstable that the threat of a collapse is imminent unless fisheries scientists' recommendations are followed. Experts from the International Council for the Exploration of the Seas (ICES) have proposed that cod catches should be limited to $50 \%$ of catch levels in 2006 to enable young fish to mature and build up the population.

\section{Herring stock recoveries promoted through good practices}

Herring live in shoals in northern seas. A single shoal may contain as many as four billion fish. Norway's spring-spawning herring stocks were once thought to be the largest single fish stock anywhere in the world in terms of their total biomass. This may have remained true into the 1950s, when North Atlantic herring stocks began to be overfished until they were almost totally exhausted So few mature fish were left in the sea that stocks could not reproduce well enough to recover. This degree of overfishing became possible in the 1960s when new types of equipment came into use, including purse seines, echosounders and hydraulic gear.

The collapse of herring stocks also affected cod populations, since herring are together with capelin the main prey species for cod. Seals, whales and many seabirds also largely depended on herring shoals for food. Herring fishing was never completely stopped, and this slowed the recovery of stocks. Strict quotas imposed in Norway in the 1980 s enabled local stocks to recover, however. The exceptionally good spawning year of 1983 represented a welcome piece of good fortune.

Icelandic summer-spawning herring stocks have also recovered. They have been fished sustainably since as long ago as 1975 , and are now at record levels.

The restoration of North Sea herring stocks is a renowned example of good fisheries management. A collapse in the late 1970s triggered a four-year ban on herring fishing in the North Sea. Over the next few years stocks recovered rapidly, but fishing was also allowed to intensify, and stocks dwindled again in the 1990s. Under new international rules herring fishing quotas were reduced in 1996, and common stock management guidelines were subsequently adopted, thanks to which North Sea herring stocks have risen again to biologically safe levels.

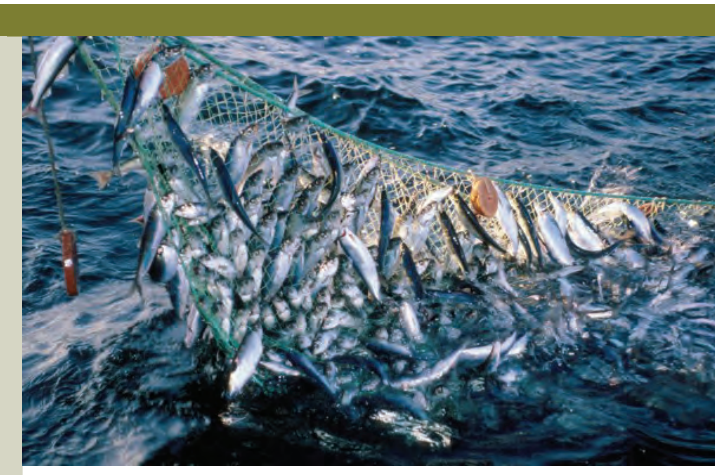

Fishing herring. Picture: Samfoto.

Spawning stocks of herring in the North East Atlantic

1000

ton

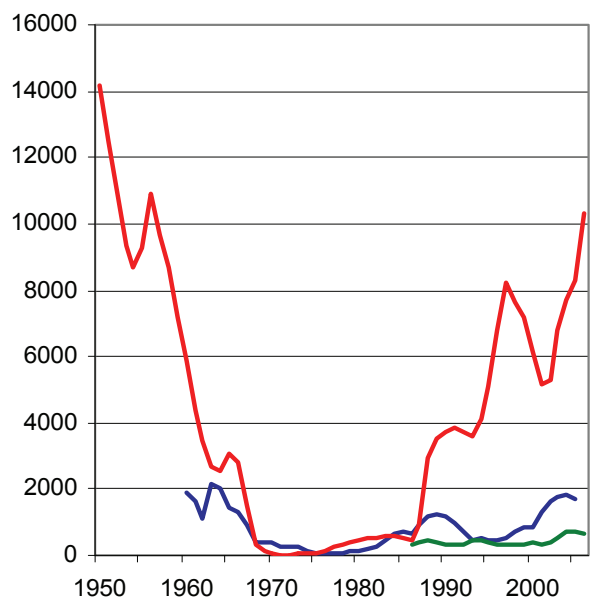

North Sea, autumn spaw ning (ICES N, V lld, llla) _ Iceland, summer spaw ning (ICES Va) Norw ay, spring spaw ning

Icelandic spring-spawning herring stocks survived a collapse in the beginning of the 1970s, and they have been fished again since 1975, nowadays at sustainable levels. The spawning stocks of the Norwegian springspawning herring and the North Sea herring have also recovered thanks to international action. The figure shows the spawning stock biomass of herring. Source: ICES Stock Assessment Summaries 2006.

Sources:

- ICES. 2006. Report of the ICES Advisory Committee on Fishery Management, Advisory Committee on the Marine Environment and Advisory Committee on Ecosystems, 2006. ICES Advice. Books 1-10. Book 2 Iceland and Greenland. Book 3 The Barents Sea and the Norwegian Sea. Book 4 The Faroe Plateau Ecosystem. Book 6, North Sea.

- ICES, Environmental status of the European seas, 2003

Federal Ministry for the Environment, Nature Conservation and Nuclear Safety, Germany.

- Hallanaro, Eeva-Liisa, Pylvänäinen, Marja \& From, Stella.

2002. Nature in Northern Europe - Biodiversity in a Changing Environment. Nord 2001:13, Nordic Council of Ministers, Copenhagen.

- The Nordic Arctic Environment - Unspoilt, Exploited

Polluted? 1996. Nord 1996:26, Nordic Council of Ministers,

Copenhagen.

Finnish Environment Institute SYKE - www.environment.fi/nordicnature

29 Nov 2007

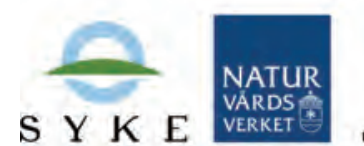

$S$ Y K E

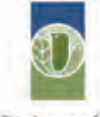

Direktocitel for
MILJøMINISTERIET

By-og Landskabsstyrelsen umhvorvisstovan
Direktoratet for Miljø og Natur

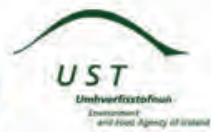




\section{Baltic cod and herring stocks - changing interactions between predators and prey}

The brackish waters of the Baltic Sea are home to about a hundred fish species, including fresheater species that have adapted to more saline conditions, as well as marine species adapted to salinity levels much lower than in the open seas. The Baltic's most important fish species in commercial terms are cod (Gadus morhua), Baltic herring (Clupea harengus var. membras) and sprat (Sprattus sprattus). The populations of these three species are closely linked, as cod are the most important predator species for both herring and sprat. At the same time, both herring and sprat feed on cod roe and larvae. This means that trends in the population of one species also affect the others. The natural balance between these species has today changed, however, as cod populations have long been very low. Stocks of both herring and sprat have increased noticeably in response to the absence of a major predator.

\section{Baltic cod fished unsustainably}

The Baltic has two distinct cod populations, which spawn in different waters. The boundary between these eastern and western populations lies near the Danish island of Bornholm. Both populations are threatened by overfishing and the poor ecological state of the Baltic Sea.

The Baltic occasionally receives ecologically beneficial inflows of oxygen-rich salty water from the North Sea, but none of these 'salt pulses' since 1993 have been strong enough to increase salinity levels significantly, or refresh the extensive areas of the Baltic sea bed where eutrophication has led to oxygen depletion. As bottom-dwelling fish, cod particularly suffer from eutrophication. They cannot reproduce well where the sea floor lacks oxygen and where salinity levels are low, since they release their roe into the open water. The eggs sink until they reach waters with salinity of $10-12 \%$. If oxygen levels in these deeper waters are less than $2 \mathrm{ml} / \mathrm{l}$, the eggs will die. The eggs of larger female cod are larger and less dense than those of smaller fish, so they float higher in the water, reducing the likelihood that they will sink down into anoxic water. This means that it would be important for fisheries to spare larger cod.

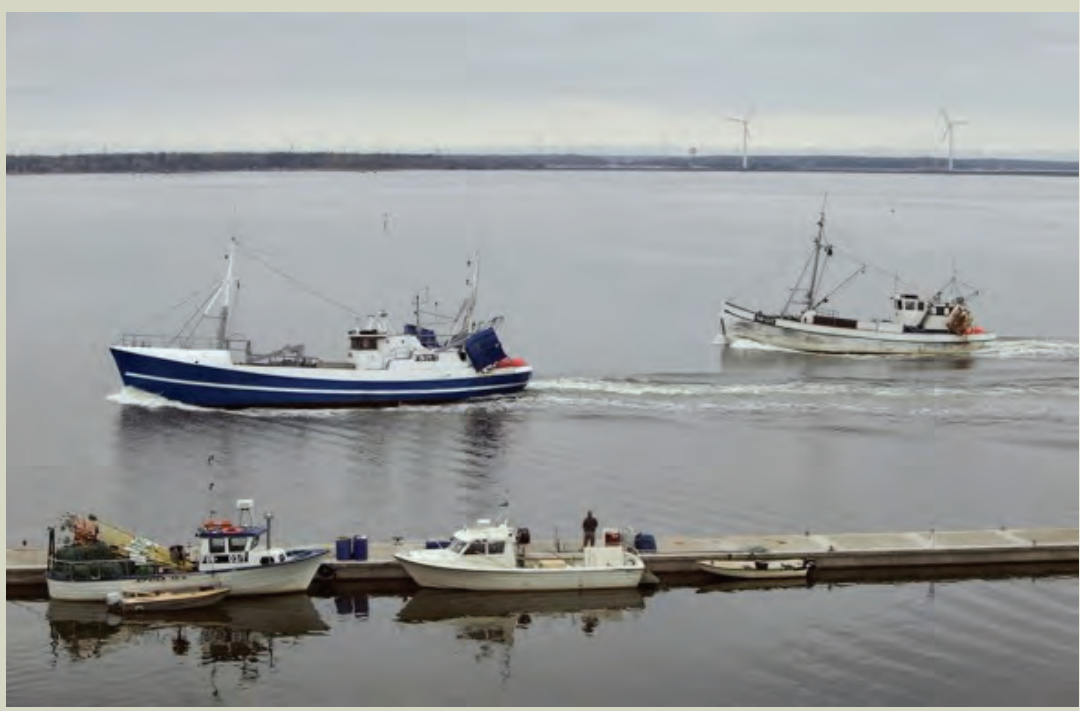

Fishing boats in the Baltic Sea. Picture: Markku Saiha/leuku.fi
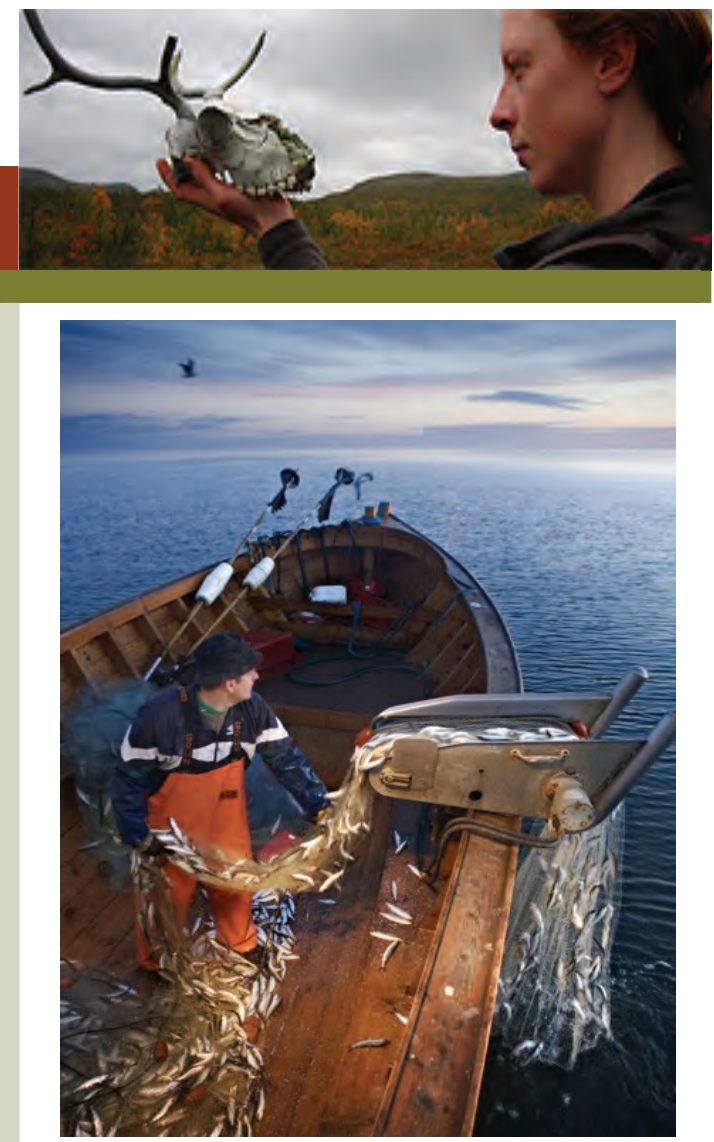

Fishing Baltic herring. Picture: Markku Saiha/leuku.fi

\section{Cod stocks in the Baltic Sea}

\section{0}

tons

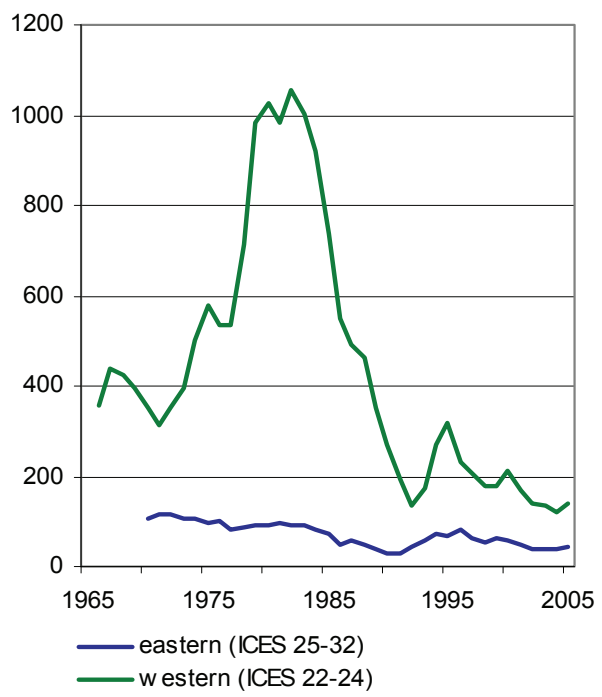

Baltic cod stocks need to be managed through international cooperation to restore them to sustainable levels and then ensure they remain sustainable. The Nordic Countries can contribute greatly to the EU's cod stock management plans, including experiences of successes achieved through fishing bans in selected waters as part of efforts to protect spawning areas and immature fish. The figure shows the total stock biomass of cod. Sources: ICES Stock Assessment Summaries 2006. 
The eastern Baltic cod population spawns in three areas in the Bornholm, Gdansk and Gotland Deeps. Due to current salinity and oxygen conditions the spawning area east of Bornholm has virtually disappeared, and spawning is only successful today in the Bornholm Deep. The spawning areas of the western population do not seem to have shrunk.

The fishing levels recommended by biologists have not been adopted, and cod stocks have consequently declined steadily. The International Council for the Exploration of the Seas (ICES) sets annual fishing quotas, but member states can still decide whether to enforce them or not. Each year the majority of the individuals within the western Baltic stock are fished. Catches include fish that are too young, and at times total catches have been larger than the mature spawning stock.

The state of the eastern Baltic cod stock is even more worrying. The spawning stock declined rapidly after the early 1980s, and now stands at just one third of the target level. Since the 1990s the stock has been seriously overfished in relation to its tolerance and reproductive capacity.

ICES this year classified the eastern Baltic cod stock as being unsustainably exploited and suffering from reduced reproductive capacity. ICES consequently recommended that the stock should not be fished at all during 2008 , estimating that such a ban would allow the spawning stock to increase to a sustainable level by 2009. In October 2007 the EU Commission's Fisheries Council approved quotas for Baltic cod fisheries and also defined the numbers of days on which cod fishing can take place. The quotas for the western and eastern cod stock have been reduced by $28 \%$ and $5 \%$, respectively. These quotas and the numbers of fishing days will be further reduced over the coming years, until stocks reach sustainable levels.

\section{Ups and downs for Baltic herring and sprat}

The Baltic herring is a brackish water variety of the Atlantic herring (Clupea harengus var. harengus), which lives and breeds throughout the Baltic Sea. Baltic herrings caught south and west of Sweden's Kalmar Strait are often sold as Atlantic herrings, which fetch a better price. Baltic herrings feed on plankton. They gather in large shoals and migrate long distances to feed and spawn. Sprats also live in shoals, mainly in the central and southern waters of the Baltic, but when their numbers are high they can also spread north as far as the Finnish coast.

Baltic herring and sprat have not undergone any complete population collapses due to overfishing as herring stocks have in other seas. But the stocks of both species exhibit dramatic fluctuations, linked to the abundance of predatory cod and the availability of food. The largest Baltic herring stock, which lives in the Baltic Proper, declined between the 1970s and the turn of the millennium, but has since recovered steadily. The herring individuals tend to be smaller and slimmer than before. Their growth has evidently slowed since the mid 1980s, as a consequence of a decline in the availability of food, and increased competition for food from rising numbers of sprat.

If fishing pressure remains stable, it is predicted that herring stocks in the Baltic Proper will increase steadily until 2015 aided by both fishing restrictions and low cod populations. Their population size is regulated by fishing, natural mortality rates, and the local populations of cod and sprat. The natural predator-prey balance seems to have been broken, however. Both Baltic herring and sprat are benefiting from the poor state of cod populations. If cod stocks recover, sprat catches might have to be limited. Since sprats are usually caught together with herrings, such controls must particularly be imposed in waters where both species are found. The EU Commission's Fisheries Council has however decided to raise the herring fishing quota in the Baltic Proper next year by $15 \%$.

Baltic herring stocks in the Bothnian Sea have also thrived in the absence of cod, and quadrupled over the period 1981-1994. Stocks in the Bothnian Bay were intensively exploited in the 1990s, and their current state is uncertain. According to ICES, Bothnian Sea stocks are today exploited sustainably, but fishing should not be increased in the Bothnian Bay. The Fisheries Council has resolved that Baltic herring quotas for these waters should be reduced for 2008 by $4-10 \%$.

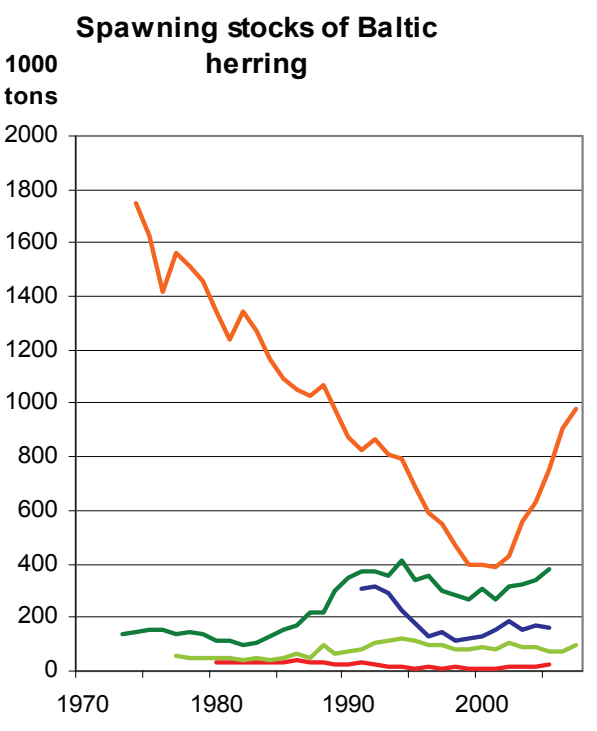

Danish straits, spring spaw ning (ICES Illa, 22-24)

Bothnian sea (ICES 30)

Bothnian bay (ICES 31)

Baltic proper (ICES 25-27, 28-2, 29, 32)

Gulf of Riga (ICES 28-1)

Stocks of both Baltic herring and sprat fluctuate greatly, due to both the size of cod stocks and other as yet unclear factors that result in marked spawning successes in certain year classes. The spawning stock of the Baltic Proper is now sustainable again having recovered from a low ebb at the turn of the millennium. The figure shows the spawning stock biomass of Baltic herring. Source: ICES Stock Assessment Summaries 2006 .

Sources:

- ICES. 2006. Report of the ICES Advisory Committee on Fishery Management, Advisory Committee on the Marine Environment and Advisory Committee on Ecosystems, 2006. ICES Advice. Books 1-10. Book 8, Baltic Sea. - Kalavarat 2006 - Fiskresurser 2006. (Fish Resources 2006) Finnish Game and Fisheries Research Institute, Helsinki, 2007.

- ICES CIEM, Environmental status of the European seas, 2003, Federal Ministry for the Environment, Nature Conservation and Nuclear Safety, Germany.

- European Commission Fisheries Council Decision 23.

Oct. 2007 In press release of the Fisheries Council of The European Commission 24.10.2007, "Commission: Council decision is good for the Baltic cod".

- Hallanaro, Eeva-Liisa, Pylvänäinen, Marja \& From Stella 2002. Nature in Northern Europe - Biodiversity in a Changing Environment. Nord 2001:13, Nordic Council of Ministers, Copenhagen.

- Eeva Furman, Harri Dahlström Risto Hamari. 1998 Itämeri - luonto ja ihminen. (The Baltic - Man and Nature) Otava, Keuruu.

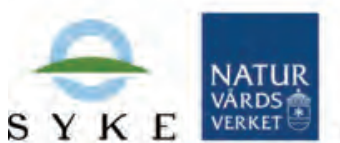

S Y K E

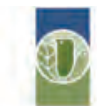

Divektovatel for

\section{MILJØMINISTERIET}

By-og Landskabsstyrelsen umhvorvisstovan
Direktoratet for Miljø og Natur

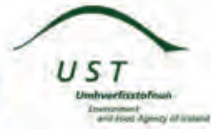




\section{The triumphant return of the white-tailed eagle}

The recovery of Northern Europe's largest bird, the white-tailed eagle (Haliaeetus albicilla) is a success story showing that active protection can save a species from extinction. About 200 years ago white-tailed eagles nested across nearly all of Western Europe, but by the end of the $19^{\text {th }}$ century they had been wiped out due to persecution. The whitetailed eagle again faced extinction in the mid $20^{\text {th }}$ century, this time threatened by environmental toxins.

\section{Threats all related to man}

The disappearance of white-tailed eagles in the $19^{\text {th }}$ and early $20^{\text {th }}$ centuries was entirely due to man. Bounties were paid in Iceland until 1905, and in Norway even into the 1960 's. In Iceland eagles also used to be killed by poisoned bait meant for foxes until such practices were banned in 1964 .

Being at the top of the food chain became dangerous for the white-tailed eagle in the 1950's-1970's, when the environmental toxins DDT and PCB nearly drove the species into extinction. DDT contamination made their eggshells extremely thin, and incubating mothers often crushed their eggs.

The use of DDT and PCB was banned in the countries around the Baltic Sea in the 1970's, but the eagles' reproduction was still affected for a couple of decades. Such problems were much less pronounced along the Atlantic coast of Norway.

White-tailed eagles were also killed by mercury and lead poisoning. Even in recent years, eagles feeding on fish from large reservoirs in Finland have been found to contain critically high concentrations of mercury, because reservoirs contain high mercury concentrations for many years after their construction. In the late 1990's white-tailed eagles killed by lead poisoning were found on the Alland Islands. These incidents occurred because a ban on the use of lead shot in the hunting of sea birds that was imposed in Finland in 1996 does not apply in Åland.

\section{...even today}

The worst threats facing white-tailed eagles nowadays include wind farms, which are becoming more common along our coasts, and power lines, especially the so-called killer pylons. These pylons lie close to shores, and are used by the eagles as lookouts. Birds sitting on these pylons can easily be electrocuted if they touch the power lines with their wings, usually resulting in instant death. On the Åland Islands, such pylons have been successfully tamed by adding an extra bar on the top, on which the birds can safely perch. In Sweden, power companies have insulated pylons and transformers with plastic hoods.

Other serious threats facing the white-tailed eagle are changes in land use, forestry and the construction of forest roads. Especially in Iceland and Norway, holiday homes, roads and industrial facilities are widely being built in eagle territories. The increasing recreational use of natural areas also disturbs the eagles. Nesting sites therefore need to be taken into account in land use planning.

In Sweden and Norway, several white-tailed eagles are killed each year in collisions with trains or cars, after landing to feed on roadkill. Many eagles could be saved by removing carcasses from road and railway verges.

Even if disturbance, persecution and poaching have declined over the years, they still occur from time to time. Eagle eggs and chicks are highly tradable, and collecting has not entirely ceased. Several eagles are killed every year by
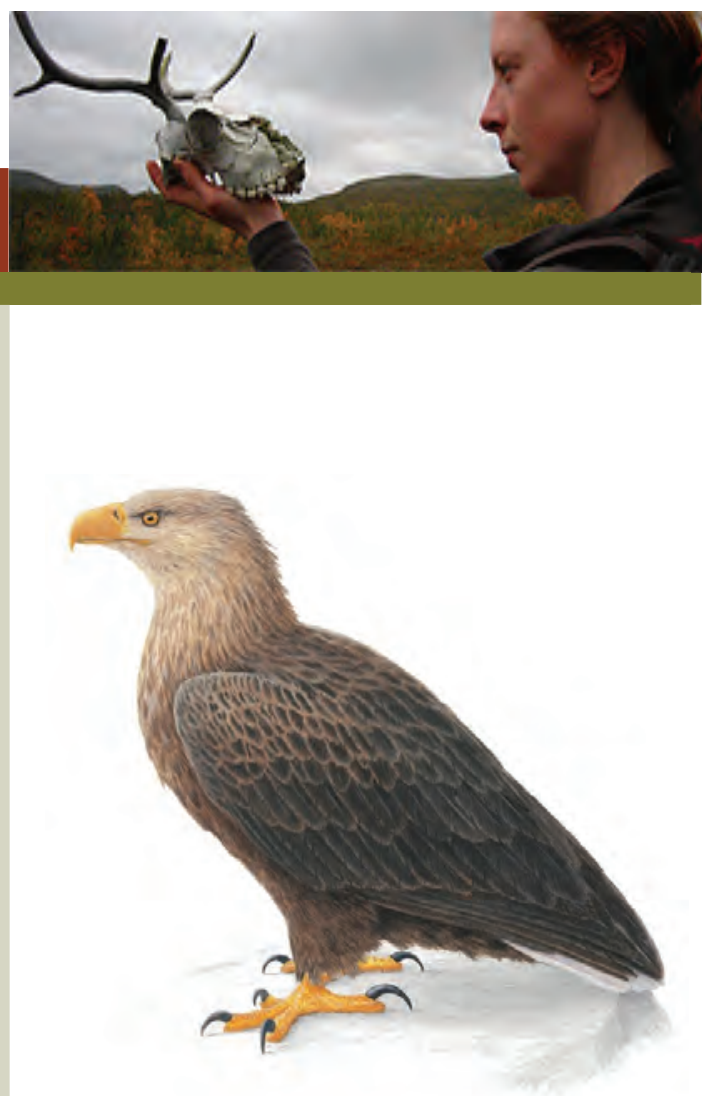

Picture: Jón Baldur Hliðberg

Occurs in Southeast Greenland, Western Iceland, and across Northern Eurasia all the way to Northeast Siberia and the Pacific Ocean.

- Rare or extinct in Western Europe; more common in Scandinavia, Finland, Germany, Poland and Eastern Europe.

- Adult birds are resident; younger birds from Norway and Finnish and Swedish Lapland tend to migrate to the Norwegian coast, and from the Baltic Sea area to Southeast Finland, the Åland Islands, and Central and Southern Sweden.

- Nests on coasts and near large inland waters.

- In wooded areas builds a large nest in a sturdy tree in treeless areas in Norway, Iceland and Greenland nests on cliff ledges or even bare ground.

- Lays 1-2 eggs, in good years even 3 .

- Wary while nesting; breeding may fail due to severe storms or human disturbance.

- Faithful to both nesting site and partner; territorie are known to have been used for 100-150 years.

- Mainly feeds on fish, birds and small mammals; in the Baltic Sea area also increasingly on cormorants and grey seal pups.

Does not kill sheep or reindeer, but feeds on carcasses. 
poachers in Sweden and Iceland. In the Nordic Countries the killing of whitetailed eagles is a punishable offence under nature conservation laws.

\section{Purposeful action vital for conservation}

The winter feeding carried out as part of Finnish and Swedish white-tailed eagle conservation projects represented a new kind of deliberate intervention designed to help protect eagles. In Sweden and the Åland Islands winter feeding was initiated in the 1960's. Pig carcasses were put out by volunteers to provide the eagles with food that was less contaminated by toxins than their wild prey.

This winter feeding was especially important for young birds, helping them to survive their crucial first winter. Such feeding still continues in Sweden, but was discontinued by the Finnish project in 2000, when the concentrations of environmental toxins in the Baltic Sea declined to safer levels. Outside of the project some feeding is still organised to facilitate eagle counts and photography.

White-tailed eagle nests and territories are nowadays protected in all the Nordic Countries, except for Norway, where the bird is common. Nesting sites and nest trees must be protected during forestry work, for instance. In Finland all nest trees are automatically protected, and artificial nests have even been built in areas lacking suitable nest trees.

Inspired by the Finnish and Swedish white-tailed eagle projects, Denmark also started an eagle project in 1992, with the aim of bringing both white-tailed eagles and golden eagles back to nest in Denmark. The project has already been successful, since 16 white-tailed eagle pairs now nest in Denmark, but the longer-term aim is to increase the national breeding population to 75 pairs by 2040 .

The white-tailed eagle is a very closely monitored species, and efforts are made to ring all eaglets while they are still in their nests. A colour-coded ringing project involving nine countries in Northern Europe was initiated in 1976. When eagles are counted from hides erected at feeding stations, observers can use telescopes to decode useful information on the birds' rings, including the time and place of ringing.

\section{A bright future ahead}

The future looks bright for the white-tailed eagle in the Nordic Countries, if the dangers posed by wind farms and power lines can be overcome, if persecution can be stopped altogether, and if land use planning and legislation can be favourably shaped. Volunteers will still be needed in the future to help with practical conservation work in all of the Nordic Countries. Even if unofficial co-operation between the Nordic Countries already exists, the establishment of a Nordic white-tailed eagle working group could be fruitful. It could even be worth following Denmark's example and instigating a Nordic Eagle Day.

Table: The status of the white-tailed eagle in the Nordic Countries

\begin{tabular}{|l|c|c|c|c|c|c|c|}
\cline { 2 - 8 } \multicolumn{1}{c|}{} & $\begin{array}{l}\text { Finland } \\
\mathbf{2 0 0 7}\end{array}$ & $\begin{array}{l}\text { Sweden } \\
\mathbf{2 0 0 6}\end{array}$ & $\begin{array}{l}\text { Norway } \\
\mathbf{2 0 0 7}\end{array}$ & $\begin{array}{l}\text { Denmark } \\
\mathbf{2 0 0 6}\end{array}$ & $\begin{array}{l}\text { Faroe Islands } \\
\mathbf{2 0 0 7}\end{array}$ & $\begin{array}{l}\text { Greenland } \\
\mathbf{2 0 0 7}\end{array}$ & $\begin{array}{l}\text { Iceland } \\
\mathbf{2 0 0 6}\end{array}$ \\
\hline Name & merikotka & havsörn & havørn & havørn & havørn & nattoralik & haförn \\
\hline Pairs & $\begin{array}{c}271, \text { of which } \\
88 \text { in Åland }\end{array}$ & 500 & $\begin{array}{c}3.500- \\
4.000\end{array}$ & 16 & 0 & $150-200$ & 63 \\
\hline $\begin{array}{l}\text { Status } \\
\text { (IUCN LC) }\end{array}$ & vulnerable & $\begin{array}{c}\text { near } \\
\text { threatened }\end{array}$ & $\begin{array}{c}\text { least } \\
\text { concern }\end{array}$ & vulnerable & $\begin{array}{c}\text { not } \\
\text { assessed }\end{array}$ & vulnerable & endangered \\
\hline $\begin{array}{l}\text { Year of } \\
\text { protection }\end{array}$ & $\begin{array}{c}\text { Åland 1924, } \\
\text { Finland 1926 }\end{array}$ & 1924 & 1968 & 1922 & 1954 & 1973 & 1914 \\
\hline
\end{tabular}

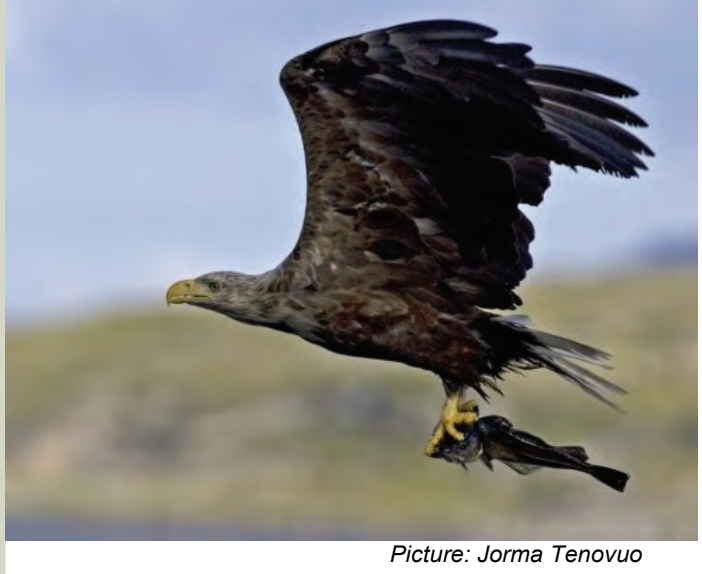

\section{Number of eaglets in the Nordic} Number
of eaglets

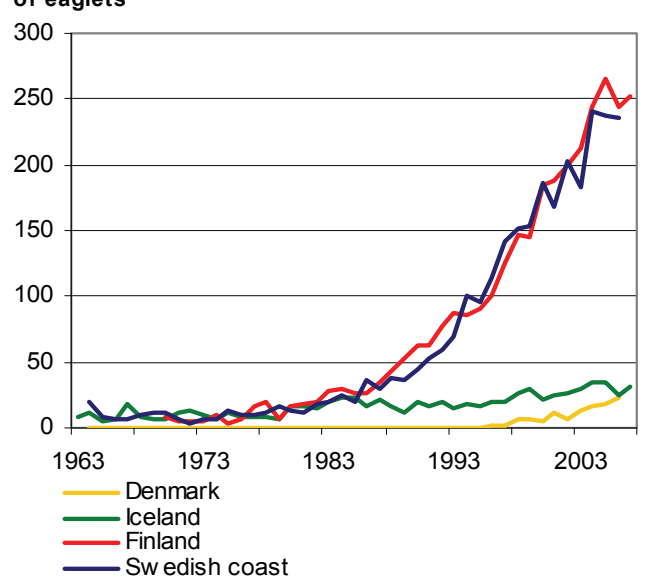

The white-tailed eagle is most abundant in Norway Greenland's white-tailed eagle population is stable and populations in all the other Nordic Countries are increasing, which can be seen in the increased number of eaglets. There are about 4,500 pairs in the Nordic Countries at present, of which about 3,500 pairs nest in Norway. No white-tailed eagles nest on the Faroe Islands, and experts are unsure whether the species has ever nested there, though there are reports of sightings and even shootings. The Norwegian population is the largest in Europe, so Norway has a great responsibility for the whole European population. Norwegian eagles have been introduced into Scotland and Ireland, where earlier local populations had become extinct. Sources: Finland - Torsten Stjernberg, WWF Finland's white-tailed sea eagle workning group, Sweden - Björn Helander, Naturhistoriska riksmuseet, Stockholm, Denmark - Ehmsen, E \& L. Pedersen (2006): Arsrapport for Projekt Ørn 2006, Dansk Ornitologisk Forening, Iceland - Kristinn H, The Icelandic Institute of Natural History

Text references on the homepage of the fact sheet: www.environment.fi/nordicnature $>$ Fact sheets $>$ The return of the white-tailed eagle 


\section{The polar bear - top arctic predator dependent on sea ice}

The most serious threats facing polar bears are all caused by man. Accelerated climatic changes and the consequent shrinking of the arctic sea ice may pose a serious threat to the species. Other concerns include high concentrations of toxic substances, potential oil pollution and increased shipping in Arctic seas, as well as hunting and disturbance in general. The Nordic Countries bear a great responsibility for the conservation of the species, since two of the five countries where polar bears live are Nordic Countries.

\section{A charismatic victim of global warming}

The loss of sea ice as a consequence of climatic warming in the Arctic poses a serious threat to polar bears. The permanent sea ice today covers a smaller area than previously, and winter sea ice seems to be forming later and thawing earlier. This means that in some areas polar bears have to spend more time on land away from their preferred hunting grounds on the margins of the sea ice.

The polar bear depends on the sea ice for hunting seals and their pups. This energy-rich diet of seal meat enables the bears to build up reserves of fat for their hibernation and for ice-free periods they spend on land, where their favoured foods are hard to find. These fat reserves also enable female bears to go without food while they give birth and raise their cubs.

During ice-free periods, polar bears are known to forage for foods including birds eggs and fish. On the southern edge of the species' range, both adults and cubs have widely suffered from malnutrition in recent years due to the shortening of the sea ice season. This has made them approach human settlements in search of food, and they are occasionally seen foraging in piles of rubbish, for instance.

\section{Harmful impacts of environmental toxins}

Arctic environments contain high concentrations of organic environmental toxins, which tend to accumulate upwards in food chains. Polar bears absorb high quantities of persistent organic pollutants (POPs) from their prey. This can disrupt their immune systems and hormonal functions, and also affect their reproduction.

Toxins build up in their fatty tissues, and when the bears use up their energy reserves, e.g. during prolonged periods on land, toxic substances are released into their bodies, disturbing their metabolic processes and making it harder for them to survive. Polar bear cubs absorb large doses of contaminants in their mothers' milk. An end to emissions of hazardous pollutants will eventually help polar bears.

Accidents related to the exploration and extraction of oil and gas reserves in the Arctic could have serious consequences in arctic environments and for polar bears. Oil slicks at sea can result in poisoning through ingestion, and also reduce the insulating properties of the bears' fur.

Whenever female polar bears in Svalbard and Greenland are fitted with bands for the purposes of satellite tracking, samples of their blood, fat and other tissues are also taken for research related to environmental toxins. The bears are also measured and weighed. Ongoing research into the impacts of climate change and environmental toxins on polar bears aims to find out if the bears can adapt to their changing environment.

\section{Hunting}

European whalers first exploited Greenland and Svalbard in the 17th century, and other hunters and explorers soon followed. Polar bears were widely hunted for their skins and meat, and also for sport. Greenlanders have always hunted polar bears for subsistence or for trade. Hunting is regulated today, with quotas set lower than previous hunting levels, but there are still worries that present hunting levels may be unsustainable for populations whose numbers are not well known.
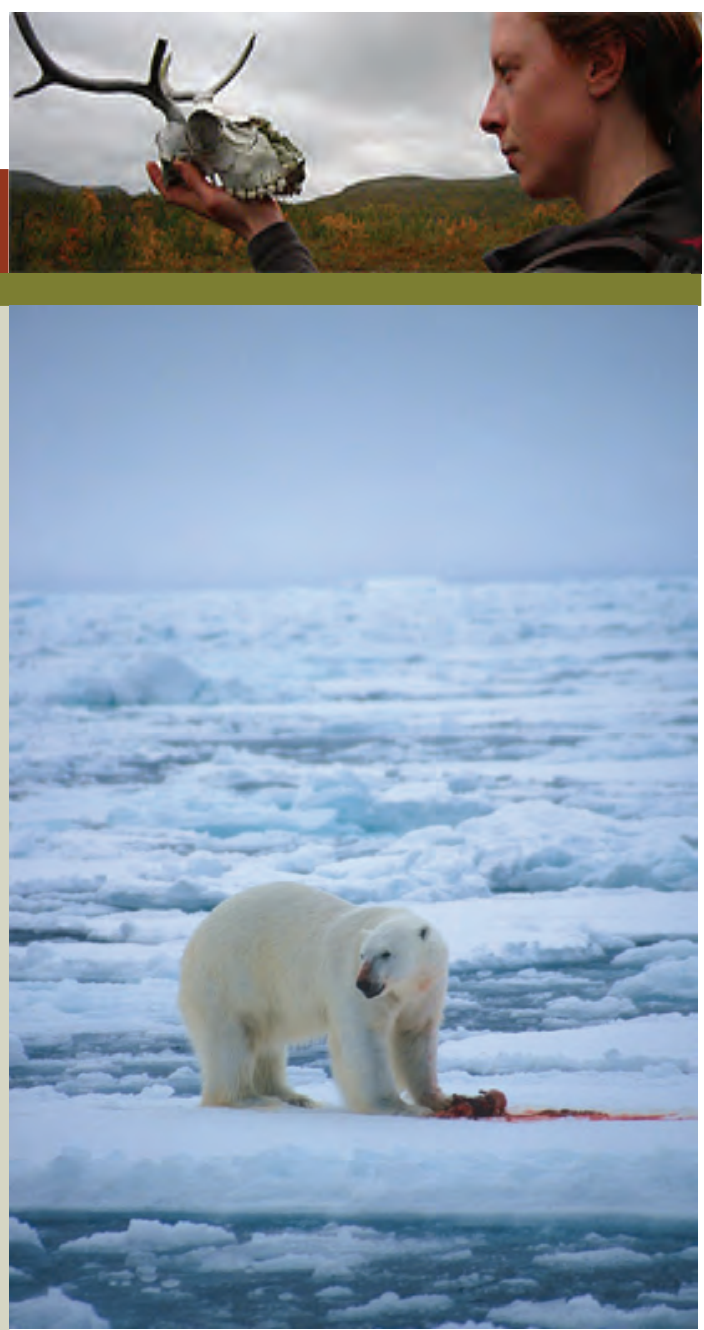

The polar bear's scientific name Ursus maritimus describes the species as a sea bear, while its name in all Nordic languages means ice bear. The polar in the English name describes the bear's polar distribution. All of these names are justifiable, since the habitat of the bear is the frozen seas of the northern polar region, and it obtains its food from the sea. Picture: Magnus Andersen/Norsk Polarinstitutt

\section{White giant of the frozen seas} - the polar bear (Ursus maritimus)

- Closely related to the brown bear (Ursus arctos)

- The world's largest carnivorous quadruped.

- Circumpolar distribution, found in Svalbard (Norway), Greenland, arctic regions of Canada, Western and Northern Alaska and northernmost Russia.

- Occasional sightings from Iceland, latest in 1993

20,000-25,000 individuals; 19 distinct populations including 6 within territories of the Nordic Countries.

- Males can weigh up to a tonne and live for 40 years

- Females typically give birth to broods of $1-3$ cubs every 3 years, with $30-50 \%$ reaching maturity.

- Fat-rich diet of seals, walrus pups, whale carcasses, belugas and occasionally other mammals such as Svalbard reindeer; also during the summer will eat seabirds, geese, eider eggs, fish, berries, grasses and kelp.

- Dependent on sea ice for breeding and feeding

- Trade in all products derived from polar bears is regulated by the Convention on the International Trade in Endangered Species (CITES). 
Hunting in Svalbard continued until as recently as 1974 when the hunting of polar bears was totally prohibited. Problematic individuals may still be killed if they endanger people and property. In the rest of the polar bear's range hunting is permitted according to quotas, which are set to ensure that hunting is sustainable, although some quotas may in practice exceed sustainable levels.

\section{Disturbances in the realm of the polar bear}

Tourism is Svalbard's most important economic activity. Around 40,000 tourists enjoy the islands' bleak arctic landscapes every year. It has been proven that snowmobiles disturb polar bears at a distance of one kilometre, and females with cubs are disturbed over even longer distances. Polar bears are inquisitive creatures, and they often approach intruders and their camps. As the sea ice recedes and arctic tourism increases, kills of polar bears in self-defence may become more common.

Protected areas have been established in both Greenland and Svalbard to limit human activity in polar bear territories. This will help to prevent unnecessary disturbance and avoid potentially harmful contacts between people and bears.

\section{Conservation measures}

All of the five countries where polar bears live are party to the Agreement on the Conservation of Polar Bears (Oslo 1973), which aims to protect and conserve the polar bear and its habitat, and ensure that any exploitation of the species is sustainable. Signatories exchange information on issues related to polar bears, and collaborate to advance polar bear conservation through research, monitoring and management.

Norway first enacted protective legislation as long ago as 1923, but these laws only covered females with cubs until 1974, since when all individuals have been fully protected in Norwegian territories. In Greenland new legislation came into force in 2005 , defining a new hunting quota system, giving additional protection to females with cubs, and prohibiting disturbance of denning sites. Icelandic legislation was revised in 1994 to prohibit the killing of any polar bears except in cases where they threaten people or livestock.

The World Conservation Union (IUCN) classifies the species as globally vulnerable, since the IUCN Polar Bear Specialist Group (PBSG) has concluded that there is a risk that the species' total population may decline by $30 \%$ over the next 45 years, due to climate change and environmental toxins. The polar bear is classified as vulnerable in Red Lists for Svalbard and Greenland.

The arctic countries acknowledge the need for regular monitoring of polar bear populations. Some populations have never been surveyed in detail, including the East Greenland population. In cooperation with Norway, Greenland has initiated a study of the movements of polar bears on the arctic sea ice, which will provide important information for future polar bear population assessments.

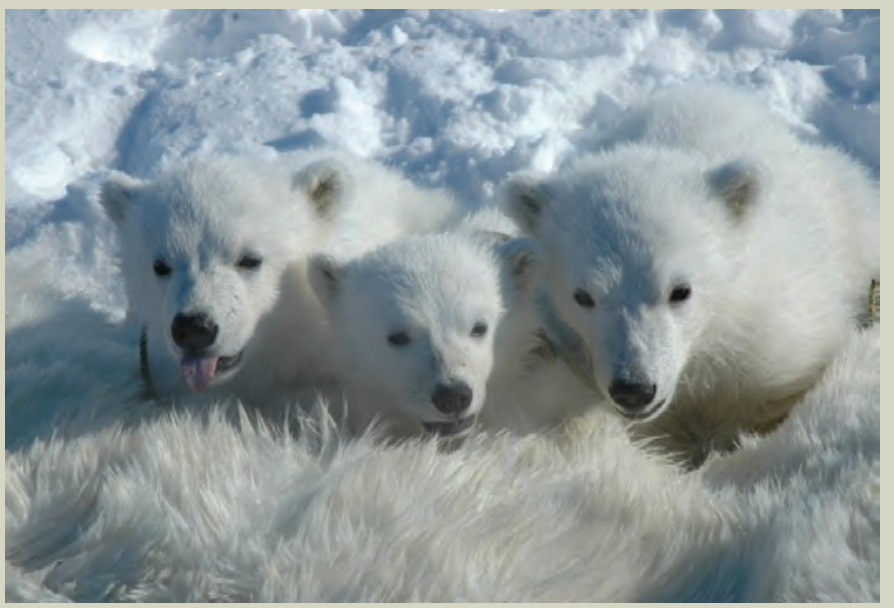

Polar bear cubs. Picture: Jon Aars/Norsk Polarinstitutt
Polar bears killed in Svalbard and Greenland Individuals

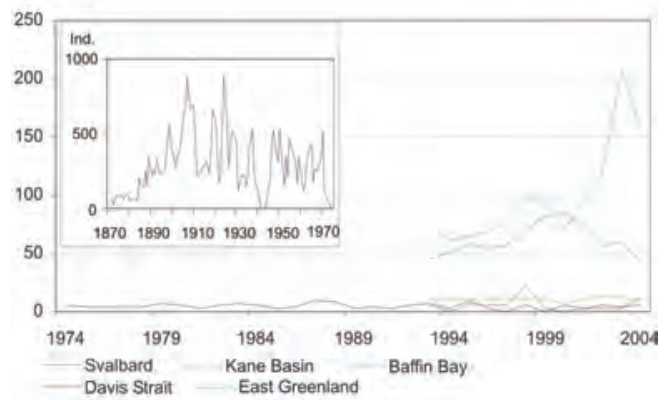

Hunting of polar bears peaked in the $19^{\text {th }}$ century.

Worldwide almost 1,000 individuals are killed annually, mostly by Inuit people as part of their traditions. The graph shows the numbers of polar bears killed in Svalbard and Greenland, with the small graph showing data from Svalbard before 1974.

Sources: Svalbard: Norsk Polarinstitutt, 17 Dec 2007. Greenland: Aars, J., Lunn, N. J. \& Derocher, A. E. 2006. Full references in the reference list of the fact sheet.

Status of polar bear populations in Nordic Countries

\begin{tabular}{|l|r|c|l|}
\hline Population & $\begin{array}{l}\text { Estimated } \\
\text { number }\end{array}$ & $\begin{array}{l}\text { Year of } \\
\text { estimate }\end{array}$ & $\begin{array}{l}\text { Observed } \\
\text { or predicted } \\
\text { trend }\end{array}$ \\
\hline Barents Sea & $2,997^{*}$ & 2004 & $\begin{array}{l}\text { data } \\
\text { deficient }\end{array}$ \\
\hline $\begin{array}{l}\text { East } \\
\text { Greenland }\end{array}$ & unknown & - & $\begin{array}{l}\text { data } \\
\text { deficient }\end{array}$ \\
\hline Kane Basin & 164 & 1998 & declining \\
\hline Baffin Bay & 2,074 & 1998 & declining \\
\hline Davis Strait & 2,252 & 2007 & $\begin{array}{l}\text { under } \\
\text { review }\end{array}$ \\
\hline Arctic Basin & unknown & - & $\begin{array}{l}\text { data } \\
\text { deficient }\end{array}$ \\
\hline
\end{tabular}

* about half of the population lives in Svalbard - only occasional individuals in the Arctic Basin - Kane Basin, Baffin Bay and Davis Strait populations are shared with Canada

Of the 19 populations recognised by the World Conservation Union (IUCN), 5 are considered to be declining; 7 are either stable or increasing; and the remaining 7 populations, which live in remote regions where human impacts are minimal, are classified as data deficient. Trends in the Barents Sea population are as yet unclear, and surveys have been scheduled for 2009. The East Greenland population is due to be counted from planes in 2010. Recent survey results from the Davis Strait population shared by Greenland and Canada indicate that it is probably increasing. The other two populations shared by Greenland and Canada are declining due to unsustainable hunting.

Sources: Davis Strait: Peacock, E. 2008. Other

populations: Aars, J., Lunn, N. J. \& Derocher, A. E. 2006.

Full references in the reference list of the fact sheet.

All references are listed on the homepage of the fact sheet: www.environment.fi/nordicnature $>$ Fact sheets $>$ Polar bear - top arctic predator dependent on sea ice.

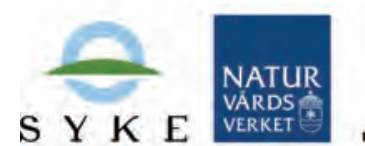

S Y K E

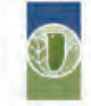

Divektoratel for
MILJØMINISTERIET

By-og Landskabsstyrelsen umhvorvisstovan
Direktoratet for Miljø og Natur

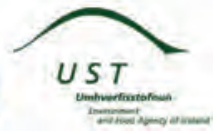




\section{Unique Nordic livestock breeds and crop varieties}

Local landrace livestock breeds and plant cultivars (cultivated crop varieties) have come about where originally wild animals and plants have been used and bred by farmers under varying local conditions. Such varieties have typically developed over long periods before the days of modern scientific selective breeding, by adapting to cope with local climates, landscapes, soils, pests and diseases. Their genetic characteristics have diversified over the millennia, making them all unique.

People have widely spread crop plants and domesticated animals around the world, and many of these varieties today occur much more widely than their wild ancestral species. Nordic landrace breeds and cultivars first started to develop more than 10,000 years ago when the first farming people settled in the region.

Nordic livestock breeds and crop varieties exhibit typical characteristics of North European domestic animals and cultivars. Crop plants often have various distinct origins where they started to be cultivated by different peoples. Nordic crop varieties generally originate in the Middle East. Many of our domesticated animals are from the same region, including sheep, goats, and possibly also pigs and cattle, although their genes also show traces of the European ancestral ox (the aurochs - Bos primigenius), and the European wild boar.

Europe is a major centre for the diversity of the world's domestic animals, as the home of more than a third of all cattle and pig breeds, and almost half of all horse breeds. It is vital to preserve the genetic diversity of Nordic landraces and cultivars to ensure that the unique genetic material does not disappear for good, even if the Nordic region is not their original ancestral home, or even a significant dispersion centre in their spread to other regions.

\section{Dwindling diversity}

The great diversity of landraces and cultivars, built up over thousands of years of traditional farming, started to decline during the last century as farming became ever more intensive and global. Many local crops have been forgotten, and farm animals have been selectively bred prioritising productivity above all else. The seed stocks of local crop varieties are vanishing as farmland crops become more uniform. The few remaining landrace stocks must be carefully conserved and prevented from interbreeding with animals of non-native breeds. Today approximately thirty crop plants provide $95 \%$ of the world food supply, with eight plant species making up $75 \%$ of our diets. Five animal species cattle, sheep, goats, pigs and chickens - provide the majority of animal food production for mankind.

Many Nordic landraces are now under threat, and some have even become extinct, like the Finnish long-haired pig. According to the UN Food and Agriculture Organisation (FAO) the world loses one domestic animal breed every month. Little is known today about such vanished breeds, though records exist of about 100 landraces now lost for ever. The most endangered breeds are mainly poultry, cows and horses, as these animals have most often been selectively bred in recent times. The reasons behind the landraces' decline include their lower productivity compared to dominant commercial breeds, new farming practices, and the globalisation of agriculture. The diversity of domestic landraces in the Nordic region is being replaced by only a few breeds from Western Europe and North America, which cannot make up for the loss of the original genetic diversity.

Crops and livestock have been selectively bred in the Nordic Countries since the early $20^{\text {th }}$ century. Modern breeders exploit the genetic diversity to produce varieties with favourable disease resistance, yields and reproductive characteristics. For now, breeders have succeeded in their main goal of boosting productivity, but the old landraces and cultivars represent irreplaceable gene banks that can still be used in the future by breeders seeking new options.

\section{Genetic diversity}

Genetic diversity within species is one of the three basic levels of biological diversity (in addition to species diversity and ecosystem diversity). - It forms the basis for differences between individuals and species, as well as the building blocks for evolution.

- It also enables populations to adapt to changing conditions.

- Genetic diversity is actively used by breeders to select favoured characteristics such as productivity or resistance to diseases and pests.

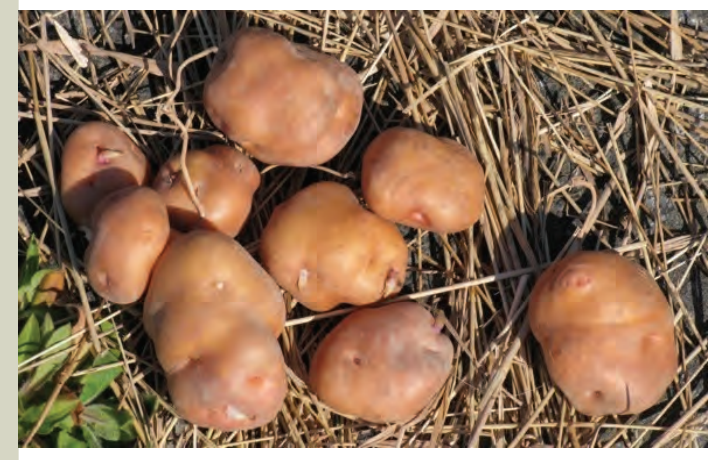

\section{Landrace potato varieties}

The potato, a native of South America, first arrived in the Nordic Countries in the $18^{\text {th }}$ century. New landrace varieties soon began to develop from these newcomers, and several hundred such varieties are thought to survive around the Nordic region. The landrace potatoes are less productive and more susceptible to disease than mo productive and more susceptible to disease than moder varieties. They are irregular in shape, which can make them more difficult to peel, but they taste more strongly of potato. Some landrace varieties are able to remain dormant longer than modern varieties without germinating, which is suitable for farming in northern latitudes. The UN has declared 2008 as the International Year of the Potato, aiming to focus global attention on the key role of the potato in fighting world hunger and poverty. The picture shows a Finnish red landrace potato, Lemin punanen. Picture: Merja Hartikainen/MTT

\section{Norwegian Vestland red cattle}

The reddish brown hornless Vestland cattle of Norway was bred from local Lyngdal and Rogaland cattle in the early 1900s. It was decided in the 1980s to keep this hornless breed pure, in recognition of the value of old landrace breeds. The hornless trait in cattle is dominant, and especially common in landraces. Vestland red cattle are small in size. In the beginning of the $20^{\text {th }}$ century cows typically weighed only about $300 \mathrm{~kg}$. Nowadays they weigh about $450 \mathrm{~kg}$, whereas Ayrshire cows, for instance, weigh about $550 \mathrm{~kg}$. The Norwegian gene resource centre is responsible for preserving the race, but fortunately some interested farmers have also chosen to raise them. Today there are 313 Vestland red cows, and 29 bulls for breeding. The importance of spreading information about breeding. The importance of spreading information about old farming practices and how such landraces should be kept is increasingly being recognised. 


\section{Conserving landraces}

Nordic experts became aware of a widespread decline in genetic resources early in the $20^{\text {th }}$ century, but the significance of landraces was only realised after some cultivars had already vanished from the fields. The Nordic Genetic Resource Centre (NordGen), which was first established as the Nordic Gene Bank in Southern Sweden in 1979, aims to preserve animal breeds and plant varieties adapted to Nordic conditions, so as to ensure the availability of genetic diversity to meet the future needs of food production, breeding and research. The centre's collections contain breeding varieties, old landraces and cultivars, as well their wild relatives.

FAO's global plan of action for plant genetic resources and the UN Convention on Biological Diversity both oblige signatory states to protect all genetic resources, including the diversity of landrace livestock breeds and crop varieties, and to use them in sustainable ways.

Landrace cultivars can best be preserved by growing them in farms or gardens in the regions where they first developed, or as close as possible to their original growth sites. They may also be grown in laboratories using test tubes and artificial substrates. Seeds can also be preserved in gene banks, under suitable laboratory conditions for slow growth, or deep-frozen in liquid nitrogen. Live animals or plants can also be relocated to new areas for conservation. One example of this is an attempt to relocate a population of the Nordic black bee (Apis mellifera mellifera) from Læsø in Denmark to South Greenland, where no honeybees are found in the wild.

A global seed bank that serves as a back-up for seed banks all around the world was established on Svalbard in 2008. The Svalbard Global Seed Vault, also sometimes called "Noah's Ark" or "the Doomsday Vault" contains seeds of all vital crop plants. The previous back-up of the Nordic Gene Bank was in an abandoned mine deep in the permafrost of Svalbard.

The spread of organic farming has improved the prospects for preserving landrace crops, since local varieties can be suited better for organic farming methods than ordinary farming, since they do not need fertilisers as much as modern varieties.

The genetic stock of landrace livestock breeds is preserved in live animals on farms, and in gene banks containing embryos and reproductive cell samples. The EU subsidises the raising of landrace breeds through rural environmental programmes. Landrace breeds are also used today in certain nature reserves and recreation areas to manage traditional landscapes, since they can thrive in natural pastures where they feed on a wide range of plants. Their low productivity is relatively unimportant when they are kept for such purposes. The Nordic Gene Bank for Farm Animals was set up in 1984 to preserve the genetic stock of local landraces.

\section{Landraces as part of our cultural history}

Landrace plants and animals are very much part of the Nordic rural scene, and they also reflect the history of farming and culinary tastes in the region. Their appearance can also tell us about the aesthetic and utilitarian values of the farmers who first grew and bred them. The loss of such varieties would clearly impoverish our cultural heritage. Landraces should therefore be preserved for their historical value as well as their genetic stock. They can also be valuable for the purposes of education and research.

It is vital that the genetic diversity of landrace crop varieties and livestock breeds should be safeguarded as a priority of national agricultural policies in all countries.

\begin{tabular}{|l|c|c|c|c|c|c|c|c|c|c|}
\cline { 2 - 12 } \multicolumn{1}{c|}{} & ko & får & häst & get & svin & höna & gås & bi & hund & kanin \\
\hline Finland & 3 & 3 & 1 & 1 & $1^{*}$ & 1 & - & - & 3 & - \\
\hline Sverige & 6 & 3 & 3 & 2 & 1 & 6 & 2 & 1 & - & 1 \\
\hline Norge & 6 & 3 & 3 & 1 & - & 1 & 2 & 1 & 7 & - \\
\hline Danmark & 5 & 3 & 3 & 3 & 2 & 3 & - & 1 & 4 & 1 \\
\hline Island & 1 & 1 & 1 & 1 & - & 1 & - & - & 1 & - \\
\hline Grönland & - & - & - & - & - & - & - & - & 1 & - \\
\hline Färöarna & 1 & 1 & 1 & - & - & - & - & - & - & - \\
\hline
\end{tabular}

* utdöd

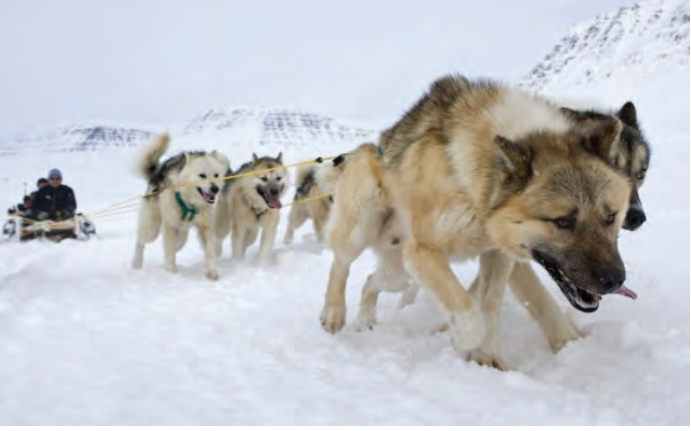

\section{Greenland sled dog}

Greenland's sled dogs are descended from wolves thousands of years ago, and they arrived together with Greenland's human settlers from Western Siberia. They can eat frozen meat and they are working dogs, not suitable as pets. Some $10-15$ years ago they numbered 30,000 , but today just 20,000 remain. Their numbers are still declining, not least due to the up to $400 \mathrm{~kg}$ of meat and fish each dog eats annually, but also because motor sledges have widely replaced dog sleds. Breeders strive to ensure no cross-breeding occurs with dogs of other varieties. The breed is legally protected through legislation on sled dogs and the keeping of dogs and cats. Most parts of Greenland are truly the realm of the Greenland sled dog, as the only other dogs allowed in these areas are service dogs - which must be sterilised. Sled dogs may not be taken to the parts of Southwest Greenland where other dogs are allowed. Picture: Carsten Egevang/ARCPIC.COM

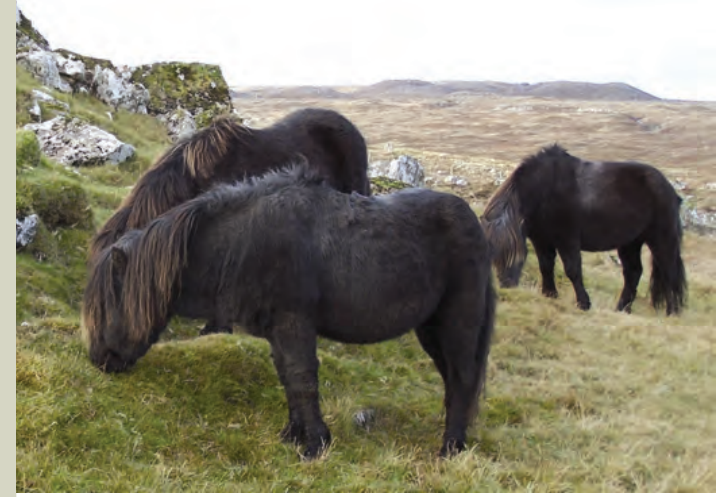

\section{Faroes pony}

The ponies of the Faroe Islands are among the oldest and purest horse breeds found anywhere. Genetically they are closest to horses from Southern England and Iceland, but they also resemble horses brought to Europe from Asia in about 200 AD. They were first brought to the islands by early Celtic and Scandinavian settlers. Their adaptations include growing think hair for the northern winter. They remained numerous in the Faroe Islands until farming practices changed in the $19^{\text {th }}$ century, and many workers moved from agriculture to fishing. But these strong but small ponies were not suited for work with ploughs or other tools, so farmers instead brought workhorses from Norway and Iceland. The numbers of these likeable ponies dwindled to just four, before the Faroese Pony Association was set up to rescue the landrace. Today the population of about 40 reproducing ponies is carefully managed. Picture: Anna Louisa Joensen.

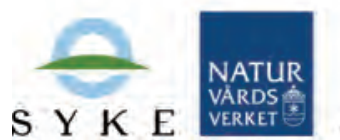

S Y K E

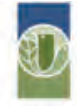

naturforvalestorning
MILJØMINISTERIET

By-og Landskabsstyrelsen umhvorvisstovan
Grønlands Hjemmestyre

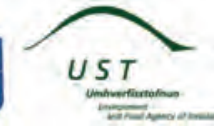




\section{Birds reacting to climate change}

Average global temperatures rose by $0.74^{\circ} \mathrm{C}$ over the period $1906-2005$. The average warming was greater in northerly latitudes, and more pronounced on land than at sea. Spring is arriving earlier in many regions, while the ranges of plants and animals are gradually shifting northwards, and in mountainous regions also upwards. Such impacts often become evident rapidly among birds. Since they are also widely studied, this makes birds good bio-indicators of climatic warming.

Research conducted for the recently published Climatic Atlas of European Breeding Birds indicates that by the end of the century birds' ranges could shift by some $550 \mathrm{~km}$ in a northeasterly direction, and shrink by about a fifth. Species will have to adapt, move to new areas, or vanish. Migration distances may well become shorter and many birds will stay longer in their breeding areas. More birds will stay for the winter in northerly regions, and some current migrants may become sedentary or partially sedentary, while remaining able to react rapidly to changes in weather conditions and food supply. The numbers of greenfinches (Carduelis chloris) spending the winter in Finland have increased, for instance, while the numbers migrating to winter in Germany have correspondingly declined.

According to climate envelope models, several bird species could eventually disappear from the Nordic region altogether. More than 20 species are expected to vanish from Finland - about a tenth of all breeding species - while many species currently breeding in the whole country might only breed in Northern Finland in the future. In Denmark some 35-40 species are expected to disappear over the next 80 years, but a similar number of new species are expected to move to Denmark. The European regions with the highest numbers of breeding bird species will shift from eastern parts of Central Europe towards the Baltic Countries and Southern Finland.

The birds most threatened by climate change are arctic and high alpine species, such as the ivory gull (Pagophila eburnea) and dunlin (Calidris alpina subsp. alpina). These species depend on arctic or alpine habitats that become rarer as climate change proceeds and the arctic sea ice and palsa mires melt and tundra ecosystems change into boreal forests. Replacing species will move in from the south, but the arctic and alpine species may be lost forever.

A new Finnish study shows that birds of the northern forests, mires and fells like the Siberian tit (Parus cinctus) and jack snipe (Lymnocryptes minimus) are particularly threatened with extinction, since climate models show they will lose most of their habitat due to climate change, and the Arctic Ocean forms a natural barrier for the northward movement of the species.

\section{Adapting to changing conditions}

The behaviour of migratory birds follows seasonal rhythms as they seek out the most favourable conditions for the various stages of their annual cycle: moulting, migrating, and overwintering, so as to be successful in their reproduction. As highly mobile and warm-blooded creatures they can readily adapt to changes in the climate and their habitats by adjusting their seasonal movements.

The earlier spring means that plants start to grow sooner and insects appear earlier. This enables migrating birds to return north and start nesting sooner, improving many species' early breeding success rates. For nesting to succeed and young fledglings to survive, however, conditions must also be favourable in early summer. Experts have noted that climate change seems to be asymmetric, with warmer spring temperatures not reflected in corresponding increases in early summer.

Breeding success rates are determined by the availability of food before and during the nesting season, and birds can suffer if their spring migration and nesting seasons do not shift in step with crucial changes in the growing season or the occurrence of insects. If they arrive when food is in short supply, birds will lay fewer eggs or none at all.

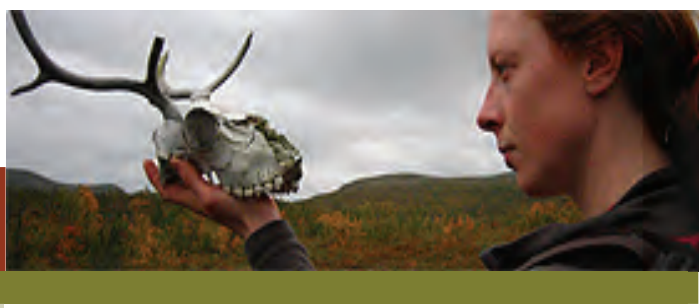

\section{Shore birds face rising tides}

More than 20 species of waders (Charadriidae) breed in the Nordic Countries. Many of the species are long-distance migrants wintering south of the Equator. Knots (Calidris canutus canutus), for instance migrate twice a year between Siberia and the coasts of Africa over Finland and Norway. The changes occurring due to climatic warming in their arctic tundra breeding habitats are not necessarily all negative, but they may result in mismatches between the timing of their arrival and conditions in their breeding areas.

Many waders depend on shallow coastal areas, such as tidal flats and salt-marshes, as their feeding and roosting sites during migration and in their wintering areas. But as the sea-level is expected to rise, these coastal habitats could disappear. In the Danish waters of the Wadden Sea, which are a very important staging area for many waders, the average sea-level has risen by $0.14 \mathrm{~m}$ over the last 35 years. It is expected to rise by almost 0.5 metres more by 2100 . This seriously threatens salt-marsh habitats around the Baltic Sea.

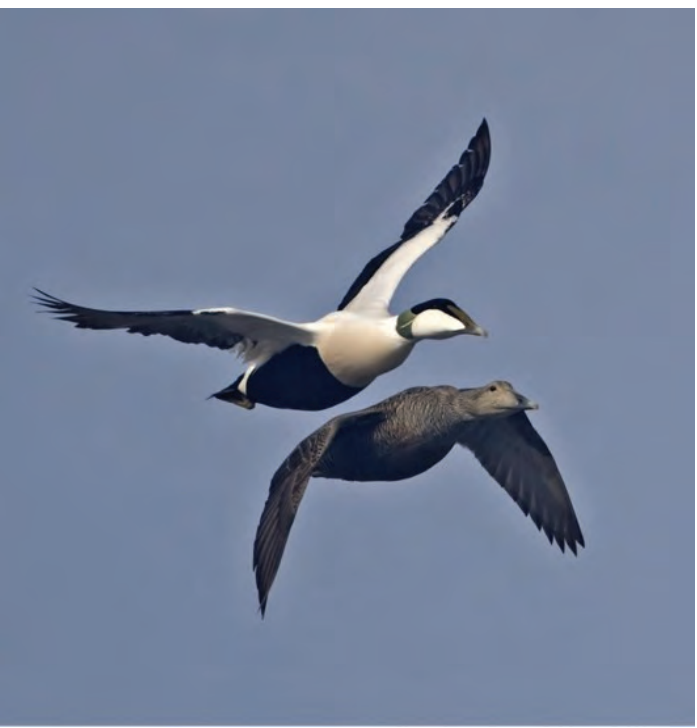

According to research conducted in northwest Iceland, the nesting of common eiders (Somateria mollissima) is negatively affected by extreme weather conditions such as wet, windy winters, which are expected to become more common as a result of climate change. Picture: Jorma Tenovuo 
Climatic warming can increase the competition for resources between sedentary birds and migrants if their nesting times become closer, and if their populations increase. Resident great tits (Parus major) and migrant pied flycatchers (Ficedula hypoleuca) returning from sub-Saharan Africa may increasingly compete for the same nest sites, if their nesting times coincide.

\section{Climatic warming must be fought}

The need to minimise the impacts of climatic warming on northern habitats and their unique species is an important reason to act to mitigate climate change. Climatic warming can seriously affect the birds of the Nordic Countries both in their breeding areas and along their migration routes through changes in their food supply and conditions for migrating, feeding and breeding. Birds' breeding, wintering and roosting areas must be protected, and the viability of their populations in their present distribution areas must be safeguarded.

\section{The black grouse - a sedentary bird species}

A warming in the climate could greatly affect populations of black grouse (Tetrao tetrix) and other galliformes. Observations indicate that several species already deviate from the most favourable conditions for their breeding. This so called mismatching phenomenon can lead to reductions in their numbers and the disappearance of cyclical trends in their populations.

The long-term monitoring of black grouse in Central Finland has revealed that the birds have been performing their courtship displays, mating and hatching their young ever earlier over the last 40 years as the springs have become warmer. But since the early summers have not been getting correspondingly warmer, their young have been hatching in unfavourable conditions, leading to high mortality rates. The species' numbers have consequently dwindled, even though adult mortality rates have not increased.

The black grouse is still common in Finland, Sweden and Norway, but in addition to climatic warming the species is also suffering from increases in predator populations. The black grouse went extinct in Denmark a decade ago Experts from Birdlife Finland have predicted that the black grouse may be one of many northern species to vanish from Southern Finland due to climate change.

\section{The chaffinch - a short-distance migrant}

In the Nordic Countries chaffinches (Fringilla coelebs) are mainly shortdistance migrants, wintering in Central Europe and Denmark. In recent times chaffinches have begun to return to their breeding areas in Norway, Sweden and Finland earlier in the spring due to climatic warming. The chaffinches now arrive 8 days sooner than 20 years ago, but other bird species have advanced their arrivals even more. In Finland chaffinches have particularly been noted arriving earlier in coastal areas. The earlier arrival does not necessarily mean that they start breeding sooner, however.

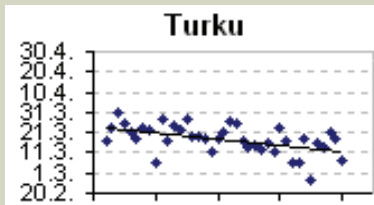

19651975198519952005

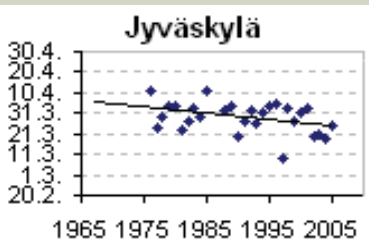

19651975198519952005

First spring arrivals of the chaffinch in two different parts of Finland 1964-2007, in Turku on the southwest coast and Jyväskylä in Central Finland. Source: Esa Lehikoinen, Turku university, observation data of birdwatching organisations.

\section{The pied flycatcher - a long-distance migrant}

Close links have been observed in Norway between spring temperatures, the arrival of migrant pied flycatchers, and the timing of the birds' egg-laying. Particularly during the warm springs over the last ten years the flycatchers seem to have been nesting slightly earlier than previously, in step with the earlier availability of their insect food and the growth of vegetation. Pied flycatchers strive to nest and lay their eggs as early as possible, to give their young enough time to mature before the autumn migration.

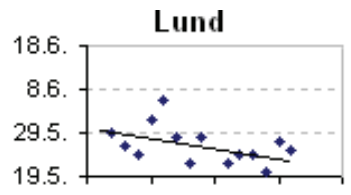

19901995200020052010

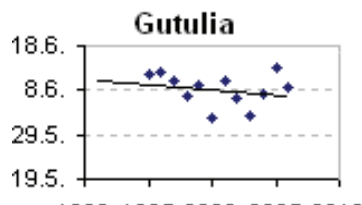

19901995200020052010

Pied flycatchers breeding earlier in Lund in Southern and Gutulia in Southeastern Norway. Source: Direktoratet for naturforvaltning.

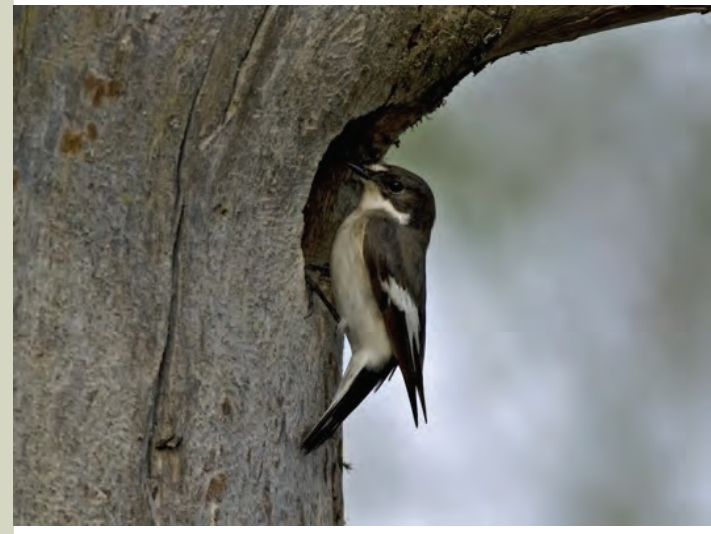

Pied flycatcher. Picture: Jorma Tenovuo

All references are listed on the homepage of the fact sheet: www.environment.fi/nordicnature > Fact sheets > Birds reacting to climate change.

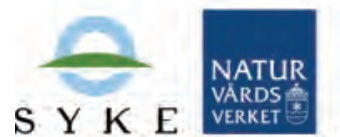

$\mathrm{S} Y \mathrm{~K} \mathrm{E}$

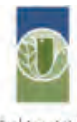

Direkdorale for
naturforvaltning

\section{MILJØMINISTERIET}

By-og Landskabsstyrelsen umhvorvisstovan
Grønlands Hjemmestyre
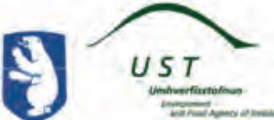


\section{Alien species in the Nordic Countries}

Plant and animal species can spread into new areas naturally, but they can also be intentionally or unintentionally introduced by man. Alien species are species that have spread outside their natural ranges due to human action. Such species can be problematic if they start to compete or interbreed with native species, or prey on them. When they move into new areas they may also spread diseases and otherwise disrupt ecosystems and habitats. In the absence of their own natural enemies it may be easy for them to out-compete native species. Invasive alien species are considered to be the second most serious threat to native biodiversity, after habitat loss and fragmentation. A total of 1,357 non-native species have established themselves in the Nordic region, and many of them already threaten our biodiversity.

People can help species to overcome natural geographical barriers that would normally prevent their spread. Seeds, spores, eggs and larvae can easily remain concealed in soil transported together with plants, in imported wood, or in ballast water transported over long distances. Increasing international trade, transportation and tourism make things worse by providing even more pathways facilitating the spread of alien plant and animal species. Some of the most unpredictable alien species are those able to hitch-hike a free ride on the bodies of cars, trains or ships - or even the shoes of unaware travellers. Canals, bridges, tunnels and other man-made infrastructures can also help species to spread. A warming in the climate may also enable many species so far considered harmless to become established in new areas.

Typically, only a few alien species will be able to adapt and establish themselves; and only some of these will have harmful impacts. The so-called tens rule predicts that one in ten imported species will spread into the wild; one in ten of these species will establish permanent populations; and one in ten of these will become invasive. Alien species that have become problematic include plants like the Japanese rose (Rosa rugosa) that have gained ground in place of native plants, and animals like the American mink (Mustela vison), whose spread has been fateful for European minks (Mustela lutreola).

Species deliberately introduced to a certain location may subsequently spread into new areas where they are unwanted. One such example is the muskrat (Ondatra zibethicus), which was intentionally introduced into Finland in the early 1900 s for hunting, but later spread into Sweden and Norway, and is now significantly affecting watercourses. Many native plants and animals have been out-competed by species originally imported as ornamental plants, crop plants or pets, which have subsequently been able to spread aggressively into the wild. Native species must always be preferred in introductions.

Worries about alien species usually concern species arriving from elsewhere, but species spreading away from our region can cause equally serious problems in other countries. It is important to prevent both the arrival and the outward spread of potentially invasive species. More information is needed on how species can spread, and how alien species become invasive.

\section{International co-operation vital on preventive measures}

Controlling invasive alien species involves hard work like digging up plants, applying pesticides, or trying to eradicate entire animal populations. Such work has already been carried out widely around the Nordic Countries, but there is still a lot more to do. Existing international agreements oblige signatory countries to work to prevent the spread of alien species, but measures have not been implemented comprehensively in practice, even where the necessary national legislation, trade restrictions, permit systems, border controls and regulations on dumping ballast water from ships are in place. Without proper supervision such obligations will remain ineffective.

The precautionary principle should always be applied, meaning that no nonnative species should be imported without a full understanding of the possible consequences. Risks should always be assessed in advance, and where damage has already been done, it should be possible to apply the polluter pays
The NOBANIS project - a Nordic initiative to compile data on alien species

Since 2004 the Nordic Countries have jointly built up and maintained a databank on alien species. This databank also contains information on non-native species whose presence has so far been harmless, but which may have harmful impacts in future. The co-operation today covers almost all of Northern and Central Europe. The databank contains vital information on the arrival and spread of alien species, their possible habitats, and their likely species, their possible habitats, and their likely ecological and economic impacts, enabling it to
serve as the basis for an early warning system on invasive alien species. NOBANIS also publishes fact sheets on individual alien species of interest. See www.nobanis.org

\section{Hogweeds (Heracleum sp.)}

Originally imported into the Nordic Countries as decorative plants, hogweeds have subsequently spread out of gardens and proliferated widely, especially in Norway. Along seashores and roadside verges native plants have been smothered by these giant weeds, which are also known as Tromso palms. Hogweeds can be harmful to people, as their sap causes serious burns on the skin. They can be combated chemically or mechanically, but are hard to eradicate totally. Growths have to be destroyed repeatedly, since they can effectively repropagate from their persistent seed banks in the ground. This makes it vital to prevent their spread in the first place by increasing awareness of their harmful impacts. In Denmark the authorities are even entitled to destroy hogweeds growing on private property.

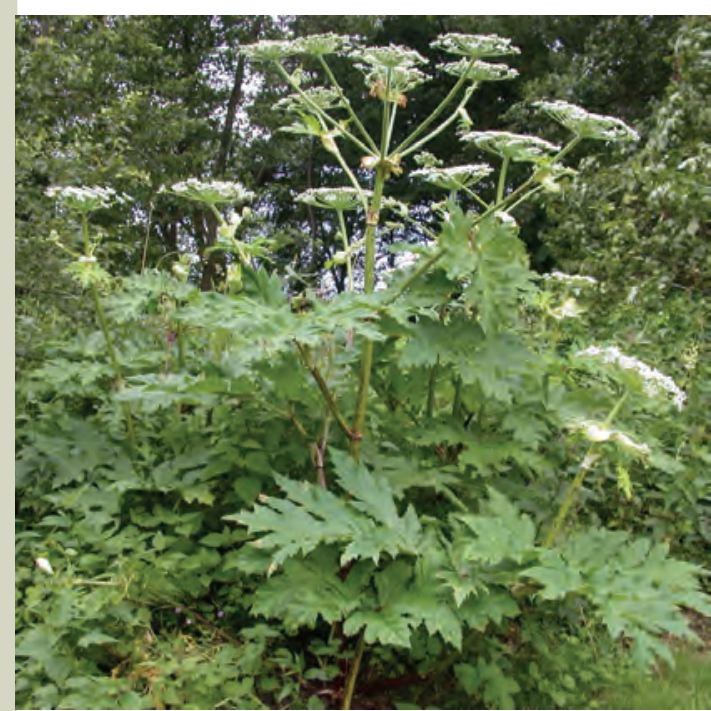

Picture: Harry Helmisaari 
principle. Measuring the financial impacts of damage caused by invasive alien species would probably encourage control measures.

An international code of conduct and related guidelines must be defined to steer actions addressing alien species. This work involves the preparation of national strategies and action plans on alien species, with specific responsibilities assigned to the various authorities. Nordic co-operation on issues related to alien species is important, since the Nordic Countries share similar conditions and often also the same problems with the same non-native species. In all of the Nordic Countries more funding and research is needed to address the ecological and economic impacts of alien species.

\section{Information sharing of prime importance}

Sharing information is a vital way to help prevent the spread of alien species. Know-how, information exchange and public awareness must all be increased, since ignorance is often a major factor behind the spread of alien species. Everyone must be made aware of the possible consequences of invasions for our native habitats, such as the gradual overgrowth of dunes and sandy shores by Japanese roses, which is particularly problematic in Denmark. Information is urgently needed, since preventive measures will ultimately be ineffective and eradication work interminable if species are allowed to continue to spread, even while they are being destroyed elsewhere.

It can be comparatively easy to share information and initiate control measures in cases where the spread of alien species results in obvious damage and expenses. Such species include the Colorado beetle (Leptinotarsa decemlineata), which can decimate potato crops; the pine wood nematode (Bursaphelenchus xylophilus); and in the near future possibly the North American comb jelly (Mnemiopsis leidyi). People are much readier to act to combat such pests than more attractive aliens, like the lupins that have spread along roadsides in many parts of the Nordic region, and Helsinki's thriving population of feral rabbits, which originates from escaped pets.

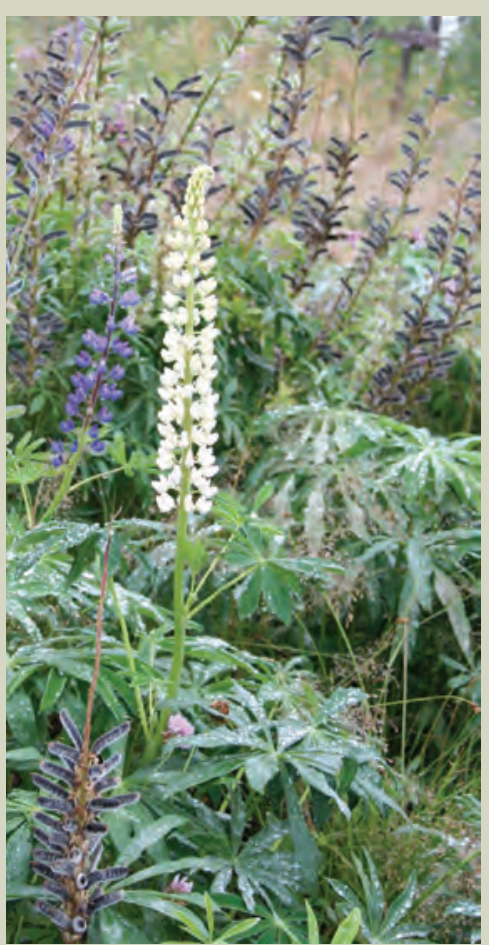

Picture: Maarit Jokine
Garden lupin and Nootka lupin (Lupinus polyphyllus, L. nootkatensis)

Lupins have also often been purposefully imported as garden flowers. Two species that proliferate aggressively - the garden and Nootka lupins - have managed to spread away from gardens in garden waste. They have also been deliberately planted along roadsides. Lupins readily bind nitrogen into the soil, which can make conditions unfavourable for native species. Ways to prevent their spread include mowing growths before they go to seed. Nootka lupins were deliberately introduced in Iceland to reduce erosion, and to improve soil conditions in wasteland. The newcomers found it easy to spread, especially where no sheep graze. Iceland's nature conservation laws stipulate the need to prevent the spread of lupins, and a set of special lupin guidelines has been issued. In the Faroe Islands, Nootka lupins imported from Iceland remain limited to gardens, possibly because sheep graze so widely in other areas.

\section{Iberian slug (Arion lusitanicus)}

A fairly recent arrival in the Nordic region, the Sweden in 1975. These hungry molluscs can now be found in all of the Nordic Countries, munching their way through almost all kinds of foliage, including even rhubarb leaves, which other snails and slugs will not eat.

Sweden has not suffered financially yet, but Iberian slugs have caused costly damage in many Central European countries and in Norwegian strawberry fields. Their capacity to destroy valuable garden plants and their ability to spread prolifically and survive the northern winter are worrying, especially since no Nordic species prey on them.

Iberian slugs thrive in damp conditions, and their young can survive mild winters. They can breed hermaphroditically, so the survival of even a single individual over the winter is enough to enable further reproduction. They can only move slowly, but their eggs and young can be unintentionally transported long distances in soil, or short distances in garden waste. Commercial and amateur gardeners are largely responsible for their spread.

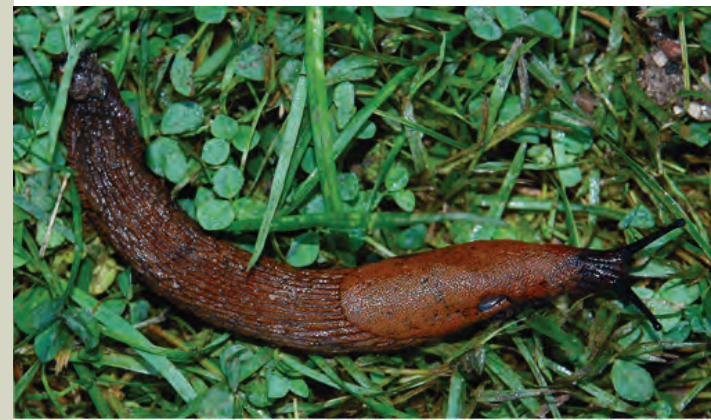

Picture: Anna Maria Hill Mikkelsen

Alien species established in the Nordic Countries, by habitat

\begin{tabular}{|l|r|}
\hline Marine & 46 \\
\hline Inland waters & 52 \\
\hline Terrestrial & 1,259 \\
\hline Total & 1,357 \\
\hline
\end{tabular}

Source: Weidema, I. R. (ed.). 2000. Introduced Species in the Nordic Countries. Nord 2000:13. Nordic Council of Ministers, Copenhagen.

References on the homepage of the fact sheet: www.environment.fi/nordicnature $>$ Fact sheets $>$ Alien species Iberian slug only established its first foothold in

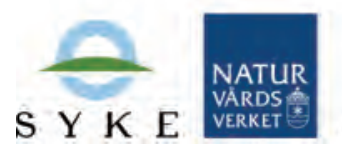

$S Y K E$

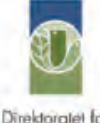

Direbtorale for
naturforvaltning
By-og Landskabsstyrelsen umhvorvisstovan

\section{MILJØMINISTERIET}

Grønlands Hjemmestyre

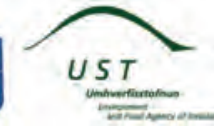




\section{Can Nordic amphibians be saved?}

\section{Alarming statistics in the year of the frog}

The year 2008 has been declared as the international year of the frog, to publicise the worrying fact that at least a third of the world's approximately 6,000 amphibian species are considered by the World Conservation Union (IUCN) to be threatened with extinction. The populations of half of the world's amphibians are declining steadily and notable extinctions have occurred since the 1970s. A total of 165 amphibian species are believed to be extinct. Amphibian extinctions are also bad news for people, since substances in the skin secretions of amphibians have been widely used to make medicines. At the moment, for instance, a new drug for treating HIV is being developed.

It is feared that half of Europe's amphibians could disappear by 2050 . In the Nordic Countries amphibians have also declined considerably, though trends are not as critical as elsewhere. Of the region's 15 species, five are listed as threatened and four as near threatened in at least one of the Nordic Countries. In Sweden, the European green toad (Bufo viridis) is critically endangered, and the pool frog (Rana lessonae) has a similar status in Norway.

\section{Habitat change and disease as major threats}

Amphibians are particularly threatened by the fragmentation and destruction of their habitat. Ponds and wetlands have widely been drained, filled in, or built over. If patches of suitable habitat become separated by longer distances, populations are no longer able to spread or interbreed. Small, isolated populations can easily dwindle or disappear as their genetic variety declines.

The ponds and pools used by spawning amphibians are vulnerable to eutrophication, overgrowth and acidification caused by human activity. Spawning ponds have to remain well lit, so their water can be warmed by the sun. Acidification disrupts the development of spawn. Spawning ponds may also become contaminated with pesticides and fertilisers from nearby farmland. In some ponds, introduced fish or crayfish may restrict amphibians' breeding by eating their spawn and tadpoles.

Disease is a serious new threat to Nordic amphibians. As many as 1,200 dead edible frogs (Rana esculenta) were recently found in a single pond in Slagelse, Denmark. It is not yet known how the ranavirus disease that killed the frogs reached Denmark from its previous range, which includes Asia, Australia, Italy and Southern England.

Experts suspect that the global collapse of amphibian populations since the 1970 s has largely been caused by the parasitic fungus Batrachochytrium dendrobatidis. This fungus causes the disease chytridiomycosis, which makes amphibians' skin swell, dry out and harden, hindering their skin respiration. This disease has been found in every continent except Asia. In Denmark it has been found in common frogs (Rana temporaria) and edible frogs, but it has not yet been observed in the other Nordic Countries.

Climatic changes can affect amphibians' breeding cycles. Sudden late frosts can be disastrous for spawn laid early due to warmer springs. Prolonged droughts may be fateful, especially after winters with little snow, when spawning areas have not benefited from influxes of meltwater. Ponds can also become warmer, drier and shallower due to climatic warming, allowing harmful ultraviolet radiation to penetrate through protective surface water layers, inducing mutations and disrupting breeding.

Female common toads (Bufo bufo) evidently fare badly during mild winters, as reflected in their smaller size and poorer condition, since they use up more energy in partial or intermittent hibernation than in hibernating right through cold winters. Weaker females produce less spawn, and are more vulnerable to disease.

Increasing traffic is also a significant threat to amphibians when they move around in their fragmented habitats which are broken up by ever denser road networks.

\section{Amphibians}

Amphibians (Amphibia) are a class of semiaquatic, cold-blooded, vertebrate animals, whose life cycles include aquatic larval forms that breathe through gills. The name amphibian derives from the Greek words amphi and bios, meaning double life, in reference to their ability to live both in water and on dry land. Amphibians cannot thrive in salty seawater. They are divided into three orders: frogs and toads, newts a caecilians. Amphibians play a vital role in ecosystems, since they are both predators themselves, and important prey for many mammals, birds and snakes. The Nordic region has nine native frog species, three toads and three newts.

\section{Tree frogs rescued from Denmark's} red list

In the 1980s the last remaining European tree frogs (Hyla arborea) on the Danish island of Zealand could be counted on the fingers of one hand. After several failures with attempted introductions, frogs were finally introduced successfully into around 60 restored or artificial ponds in western Zealand. The local population now numbers well over 1,000 , and is spreading into new territory in all directions. Around 15 years ago the population on the island of Bornholm was also threatened, but the island's tree frogs are thriving today thanks to habitat restoration measures. Such actions have enabled the species to be removed from Denmark's national Red List.

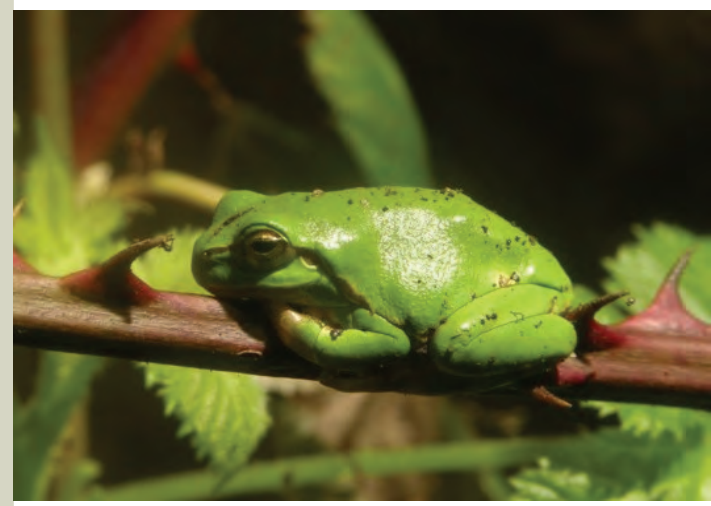

Measures to protect the European tree frog have been successful also in Sweden. As a result of habitat restoration, tree frog populations in Scania have quadrupled over the last 20 years. The region is now home to over 10,000 breeding males, found in more than 800 localities. Photo: Niels Sloth 


\section{Working to protect amphibians}

In Finland, Denmark, Sweden and Norway all amphibian species are protected. The most important way to conserve amphibians is to protect their habitats, such as ponds, wetlands and the moist areas where they spend the winter. In Denmark, all pools and ponds larger than 100 square metres are protected as amphibian habitat. In Southern Finland, any actions that would change the natural state of ponds of less than a hectare are prohibited, and the immediate surroundings of ponds must be managed in ways that preserve their natural features. Existing ponds may be made more favourable for amphibians through habitat restoration measures, and new pools can also be excavated. Such actions can preserve existing occurrences and encourage future population growth. Ponds may also be dug deeper in places, to ensure that water will remain present during droughts, and to protect pond life against ultraviolet radiation.

Climate change is an important factor in the conservation of amphibians, as it can worsen many of the threats they already face. Ponds will dry out more often if the summers become warmer. Changes in temperatures and moisture levels could facilitate the spread of chytridiomycosis. If conservation measures are not scaled with the impacts of climate change in mind, their effects could be cancelled out.

The situation remains worrying, but encouragement can be gained from the successes of local conservation measures fruitfully carried out in the Nordic Countries and elsewhere, involving habitat restoration work and introductions of amphibian populations.

\section{New homes for Norway's rare pool frogs}

Pool frogs (Rana lessonae) were first recorded in Norway as recently as 1986 , but monitoring of their population only began 10 years later. The small population, found in three ponds in the county of Aust-Agder, fluctuated around levels of 15-50 adults of reproductive age, depending on the harshness of winters. Due to its critically endangered status in Norway, an action plan was drawn up for the species in 2006.

The authorities in Aust-Agder got to work immediately, removing from the ponds any fish that would eat the frogs' spawn and tadpoles; ensuring that no new fish could get into the ponds; cutting back vegetation over the ponds; and digging suitable new ponds. Frogs have already been seen in four of the five new ponds, and it is hoped that they will begin spawning in summer 2009. The plan envisages that more new ponds will be created in Aust-Agder to ensure the frogs will have a dense enough network of ponds.

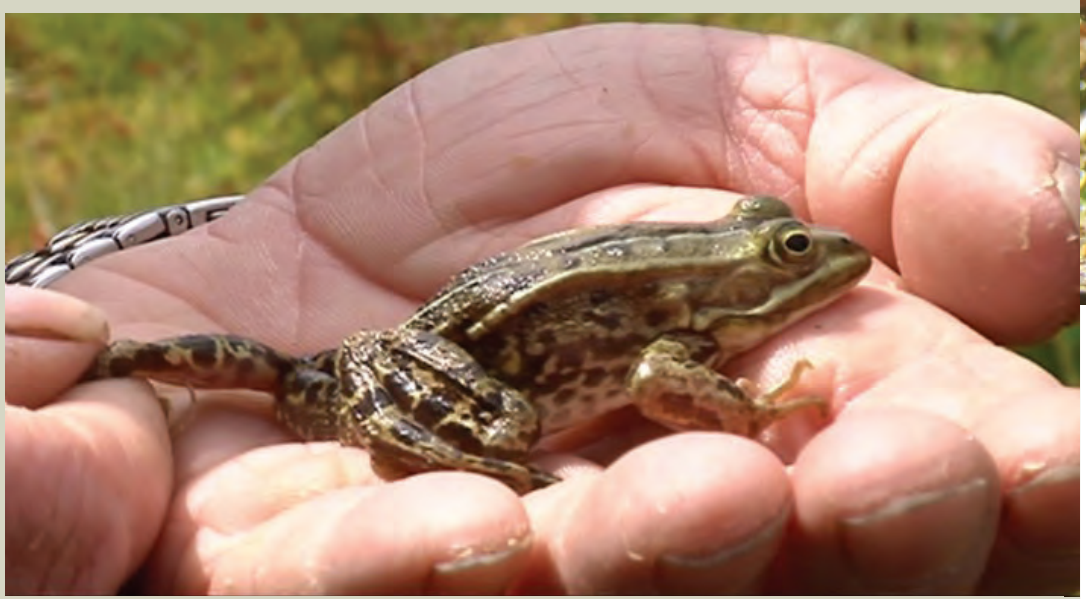

Pool frog. Photo: Svein Nic. Nordberg

\section{Helping great crested newts to survive}

Great crested newts (Triturus cristatus) face the same threats as other amphibians, including the loss, deterioration and fragmentation of their pond habitats. They are classed as vulnerable in Norway, and also in Finland - where they are the only amphibian to be the subject of specific conservation actions. In Sweden the great crested newt is classified as "least concern", but inventories in 2005 showed that its populations have declined. Sweden and Norway already have species-specific action plans in place, and in Finland a similar plan is under preparation.

New ponds have been dug and existing ponds restored to benefit great crested newts. Fish have been removed from ponds to reduce predation on spawn and tadpoles. The shores of ponds must also be managed, ensuring they are not excessively cleared, to preserve suitable places for the newts to rest during the day and hibernate each winter. Broad-leaved trees should be favoured, and fish should not be introduced where none live naturally. It is important that landowners and foresters are made aware of the newts' presence, and how to consider them. Minor actions can often make a great difference to the newts' prospects for survival.

Finland, Estonia and Denmark jointly ran an EU LIFE Nature project over the period 2004-2008 to safeguard favourable habitat conditions for the newts and keep their populations viable. The project has also enhanced collaboration with landowners and local forestry associations, and increased awareness of the species and its ecology.

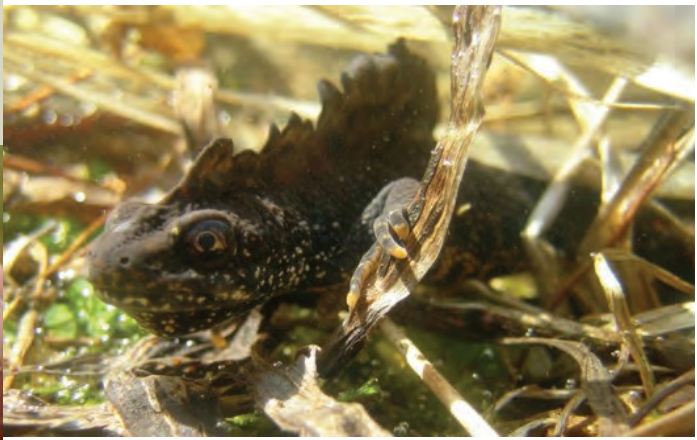

A male great crested newt on the bottom of a pond in the spawning season. Photo: Ville Vuorio

All references are listed on the homepage of the fact sheet: www.environment.fi/nordicnature > Fact sheets $>$ Amphibians in the Nordic Countries

Finnish Environment Institute SYKE - www.environment.fi/nordicnature

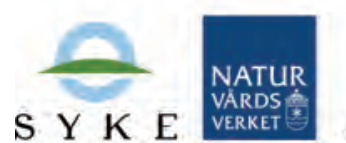

S $\mathrm{Y} K \mathrm{E}$

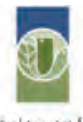

Direbtorale! for
naturforvaltning
MILJØMINISTERIET

By-og Landskabsstyrelsen umhvorvisstovan
Grønlands Hjemmestyre

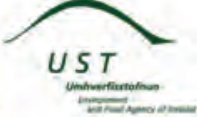




\section{Towards sustainable reindeer and sheep grazing in the Nordic Countries}

The impacts of grazing on biological diversity can be either negative or positive, depending on the type and number of livestock, the nature and productivity of the biotopes they graze, the intensity of grazing, and seasonal conditions.

In the Nordic region natural pastures are most widely grazed by reindeer and sheep. Grazing affects local ecosystems in many ways. Entire plant communities can be reshaped, with vegetation damaged or even completely wiped out where grazing has been very intense. This increases erosion and can lead to the total loss of soil cover. On the other hand, biodiversity can benefit from sufficient grazing, since it prevents the overgrowth of pastures. The Nordic Countries need to ensure that natural pastures are used sustainably in ways that benefit biodiversity. Different livelihoods and land uses must also be harmonised.

\section{Effects of reindeer grazing on vegetation}

The biodiversity of natural pasturelands and the Nordic region as a whole is affected by both the declining diversity and increasing uniformity of vegetation as a consequence of overgrazing, and conversely the overgrowth of pastures due to insufficient grazing. Alternating periods of intense and light grazing together with moderate trampling create the best conditions for many demanding plants, as long as periods of intense grazing are not too long. Northern fell biotopes are particularly sensitive to intense grazing, since they are characterised by harsh climatic conditions, thin soils, slow soil formation, intense erosion by wind and water, low vegetation productivity rates, and in many places also steeply sloping terrain.

In winter, grazing reindeer primarily rely on easily digestible lichens, horsetail lichens, grasses and dwarf shrubs for nourishment, while in summer they feed more on forbs and leaves. Overgrazing has resulted in the spread of plants shunned by reindeer due to their indigestibility, such as tougher grasses, forbs, sedges and mosses. If the animals cannot move to new pastures, these plants will also be eaten, leaving patches of land devoid of vegetation and vulnerable to erosion. Pastures are generally able to recover fairly rapidly when grazing pressure eases, except for lichen pastures, which only regenerate very slowly.

The sizes of reindeer herds were formerly limited mainly by weather conditions and the carrying capacity of the pastures used for winter grazing. During periods with heavy snow cover, reindeer may starve when lichen become inaccessible. Herders in Finland today put out silage and hay for their reindeer Such winter feeding and the medication of reindeer against parasites enable herders in many regions to keep larger herds than natural pastures could otherwise sustain. Also the erection of fences to limit the movements of reindeer has resulted in local overgrazing.

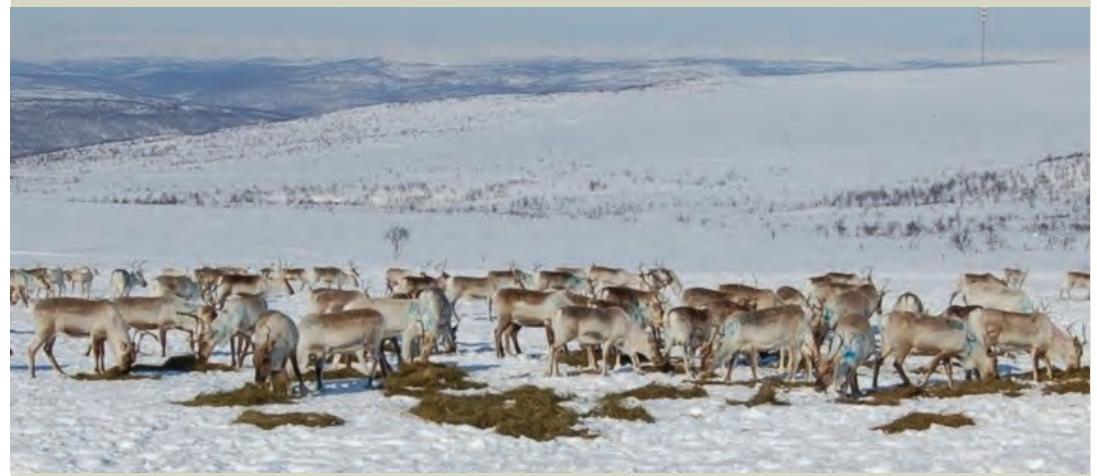

Silage and hay is put out for reindeer in Finland during the winter. Photo: Mauri Nieminen

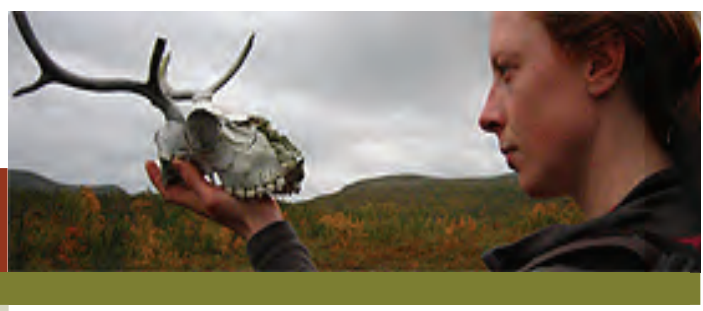

Wild reindeer and sheep in the Nordic Countries

Wild reindeer have lived in the Nordic region for more than 10,000 years, since the end of the lce Age. In Northern Scandinavia and Northern Finland domesticated or semi-domesticated reindeer have been herded by local people since the $9^{\text {th }}$ century, or even earlier. Reindeer herding became more of a professional livelihood from the 1600 s onwards. Reindeer are today grazed in the northern regions of Norway, Sweden and Finland on natural pastures located mainly in forests and on treeless fells.

Sheep are raised in all of the Nordic Countries, but the overgrazing of natural pastures is only problematic in the Faroe Islands, Iceland and Greenland. Sheep were first brought to these islands by the Vikings in the $9^{\text {th }}$ and $10^{\text {th }}$ centuries.

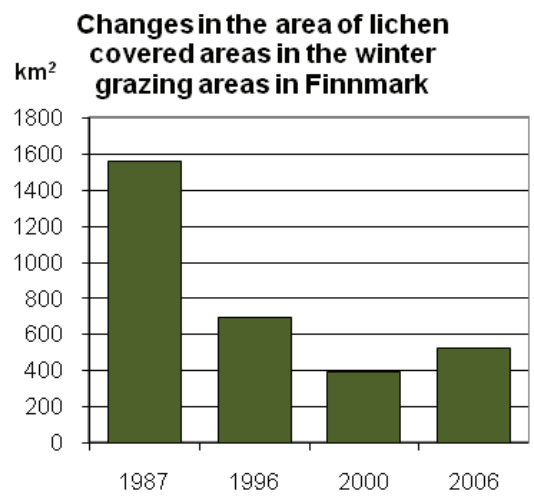

Lichen covered areas in Finnmark have slightly increased in the 2000's. Source: Norut As

Norway's Finnmark province has high reindeer densities. In summer the reindeer graze on pastures near the coast, while their winter pastures are higher up on inland fell heaths. The winter pastures in Finnmark were in good condition until the 1980s, but have subsequently been seriously overgrazed. Since a reduction in reindeer numbers during the herding season $2000 / 2001$, herds have grown again, though the extent of lichen pastures also increased between 2000 and 2006, when the last satellite surveys were conducted. A relative lack of snow in recent winters has enabled reindeer to feed over wider areas. After periods of heavy snow the lower parts of the fell plateau become covered in deep snow, and the windswept higher areas with less snow can become overgrazed under such conditions. When the snow remains shallow in lower areas, the higher parts of the plateau do not suffer from such concentrated grazing pressure. 
The most nutrient-rich pastures suffer greatly from summer grazing and trampling. Mountain birch and willow stands may dwindle where grazing prevents their regeneration. In less fertile lichen heathland forests and open areas summe grazing can seriously reduce vegetation cover, especially alongside reindeer fences. In their winter pastures, reindeer only damage the lichen cover in small patches where they dig out food from under the snow.

Finland's reindeer husbandry region covers about a third of the country. Finland's fell regions are intensely grazed in places, both in summer and in winter. Intensive year-round grazing of the same areas has led to a worrying decline in slow-growing lichens, even though during the summer reindeer mainly feed on forbs and the leaves of trees and shrubs, hardly ever grazing on lichen. Lichen growth is clearly suffering more in the animals' summer pastures, however, largely due to trampling, which can easily destroy fragile lichen cover when there is no snow on the ground. Finland's lichen pastures have been declining for a long period. Pastures are only regenerating well in a few areas of winter pasture in northernmost Finland. Elsewhere they are either seriously depleted or only regenerating slowly.

On the fells of Northern Sweden, erosion and damage to vegetation was widely reported in the 1990s. More recent surveys have shown that the damage caused by reindeer grazing and trampling sometimes observed along reindeer fences should not be interpreted as affecting the country's fell region as a whole. The situation in Northern Sweden is not comparable to conditions in Norwegian Finnmark or Northern Finland, considering the impacts of intensive reindeer herding in these areas.

\section{Impacts of sheep on the islands of the North Atlantic}

In the Faroe Islands, intensive sheep grazing exceeds the regenerative capacity of vegetation under current climatic conditions. If grazing ended, willow trees could grow on the Faroe Islands, since they lie south of the northern limit for tree growth. The islands are today grazed by around 70,000 adult sheep, at an overall density of two hectares per sheep, which is just inside the limit of overgrazing. In summer, sheep are grazed on natural pastures, while in winter they also graze in fields and grassy areas in the islands' villages.

At its worst, intense grazing can combine with weather conditions to result in the complete loss of vegetation and serious soil erosion. Iceland and Greenland suffer from similar problems with the loss of vegetation on natural pastures, and the consequent soil erosion. The impacts of sheep grazing on erosion in the Faroes are monitored on the islands of Streymoy and Sandoy, where pastures are fenced.

In Iceland, sheep are allowed to graze freely each summer. In recent years this practice has resulted in less ecological damage than previously, because the number of sheep in Iceland has been halved over the last 30 years, radically reducing the intensity of grazing. Natural pastures have also benefited from administrative measures promoting their sustainable use. About $40 \%$ of Iceland suffers from severe or extremely severe erosion. A further quarter of the country is beginning to be affected by erosion, though in such areas this trend could still be reversed through changes in land use practices or simple measures to increase vegetation cover. The extent to which these erosion problems are due to earlier widespread overgrazing is not known, since natural processes such as erosion by wind and water have also contributed to the current state of Iceland's soils. Grazing still worsens erosion in some areas, since pastures in Iceland are still grazed by almost half a million sheep and 70,000 horses.

In Southern Greenland, commercial sheep farming began in the early 1900s using sheep imported from the Faroe Islands and Iceland. For about 50 years sheep were grazed on mountain pastures all year round, and their numbers fluctuated greatly due to a lack of shelter and fodder, as well as unfavourable climatic conditions. Sheep farming in Greenland today is based on sustainable grazing practices. Sheep only graze freely during the summer, and are fed indoors during the winter months. Sheep numbers have stabilized at around 20,000 adults, and even though overgrazing still occurs on a local scale it is thought that there would be room in Southern Greenland for twice as many sheep.

All references are listed on the homepage of the fact sheet:

www.environment.fi/nordicnature $>$ Fact sheets $>$ Reindeer and sheep grazing

\section{Social implications of grazing}

Ecologically sustainable land use practices in the context of natural resource exploitation are vital for the preservation of biodiversity. The numbers of animals put out to graze should be proportionate to the productivity and regenerating capacity of pastures, so as to preserve their biodiversity. To help natural pastures recover and enhance their biodiversity, pasture rotation should be improved, with grazing channelled into resilient areas and areas that are becoming overgrown. But if the climate goes on changing in line with current trends, and livestock farmers are unable to adjust grazing to favourable levels according to each area's needs, many of the biotopes associated with the Nordic region's fell ecosystems will continue to change in terms of the abundance of their characteristic species.

Reindeer herding is one of the oldest traditional livelihoods of the peoples of the Nordic region, and its survival is necessary to preserve an essential part of our cultural heritage. But it remains vital to harmonise both reindeer herding and sheep farming with other livelihoods and land uses, including nature conservation. Reducing the numbers of grazing animals is also a social issue that directly affects the livelihoods of herders and farmers. If pastoral farming and the numbers of grazing animals need to be reduced significantly, society will have to provide alternative sources of income for such groups.

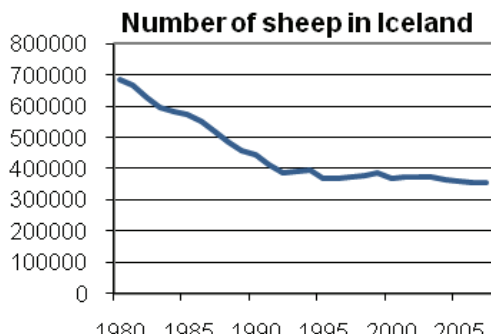

The number of sheep in Iceland has been halved over the last 30 years. Source: Statistics Iceland

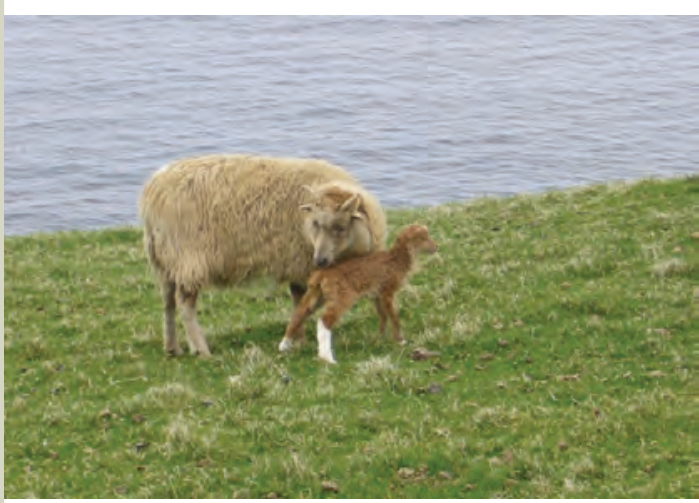

Sheep graze freely in the Faroe Islands. Photo: Anna Maria Fosaa

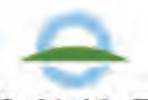

$S Y K E$

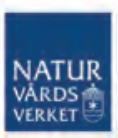

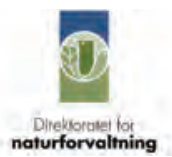

MILJØMINISTERIET

By-og Landskabsstyrelsen

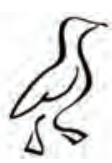

Grønlands Hjemmestyr 


\section{Nordic inland waters successfully restored}

Inland waters have rich biodiversity. Their species assemblages, food chains and biological productivity are shaped by the structure and history of the water bodies and drainage basins, and the distributions of aquatic species. Important physical aspects of water quality for aquatic species include water transparency, oxygen content, nutrient levels, acidity, and concentrations of hazardous substances.

Human activities affect inland waters in many ways. Airborne pollution can result in acidification, while nutrients in wastewater effluent lead to eutrophication. Both of these trends also alter the species assemblages of aquatic ecosystems. Logging, mire drainage and peat harvesting additionally affect water bodies by changing the amounts and characteristics of runoff. We also widely reshape our inland waters physically: by regulating water levels, by building, and by clearing or straightening their channels. Climate change can also affect the state of inland waters and their capacity to recover from changes.

\section{Acidification}

Burning fossil fuels releases acidifying oxides of sulphur and nitrogen that can enter water bodies and their catchment areas in precipitation. Intensive forestry can also worsen acidification. In the Nordic region acidification has particularly been problematic for lakes and rivers in Southern Scandinavia and Southern Finland. To make matters worse, the naturally acidic soils and bedrock of Fennoscandia only have a low buffering capacity, meaning that they do little to neutralise acidic precipitation before it enters water bodies.

As acidity levels increase, aquatic species gradually disappear in order of their sensitivity to acidity. The most sensitive species include salmonid and cyprinid fish, and bottom-dwelling animals such as crayfish, shellfish, gastropods and leeches. Insects that are aquatic at some stage of their life cycle may also vanish - together with the birds that feed on them. In acidic water aluminum and other toxic metals can be released, contaminating aquatic organisms. Aluminum, for instance, can adhere to the surfaces of the gills of fish and bottom-dwelling animals, hindering respiration.

Acidification became a major problem in the Nordic Countries in the 1960s, following a period of intense industrialisation, and at a time when emission treatment technologies were still very primitive. Acidifying emissions have more recently been curbed thanks to international controls and technological improvements, and consequently the airborne deposition rates of acidifying pollutants have declined. The most effective way to restore acidified inland waters to their natural state is to enforce emission reductions through international air protection policies

\section{Eutrophication}

Inputs of nutrients such as nitrogen and phosphorus in industrial and municipal wastewater and runoff from farmland raise the biological productivity of aquatic ecosystems. Aquatic plants, algae and plankton consequently proliferate. This process of eutrophication can lead to algal blooms and the overgrowth of water bodies. Once under way, eutrophication is hard to stop, since the process feeds itself when nutrients are eventually re-released from increased quantities of decomposing biomass, fuelling further growth through a phenomenon known as internal loading.

Eutrophication tends to reduce species diversity. Certain kinds of fish disappear from eutrophic water bodies. Light cannot penetrate into the murky water, so submerged plants and bottom flora also vanish. Eutrophic lakes have lower recreational value, as their shores become coated with slime and overgrown with reeds. Algal blooms stop people swimming, and cyprinids take over from fish species more commonly caught for the table. Water bodies suffering from severe eutrophication are particularly common in agricultural areas of Denmark and near major towns or fish farming facilities.

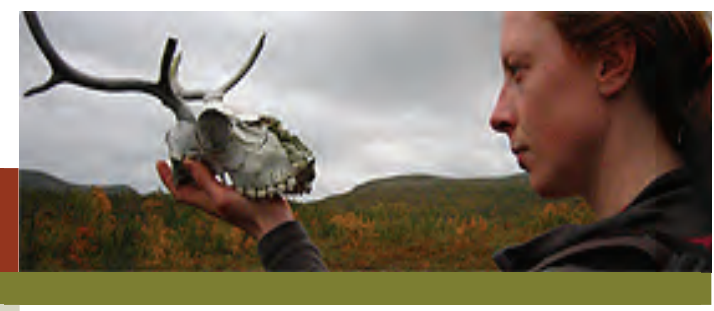

\section{Recreational waters restored in Copenhagen}

Three lakes in the Danish capital, Sankt Jørgens Sø, Peblinge Sø and Sortedamss $\varnothing$, are valuable as recreational amenities and for their interesting histories. They are made up of five distinct basins that have formed as a consequence of human activity. They are largely fed by underground canalised rivers that bring water from the Utterslev Mose wetland and Lake Emdrup. The lakes were protected back in 1966, but they remained in poor condition due to their previous contamination with wastewater until large-scale restoration work began in 2002. Nutrient runoff to the lakes declined after 2000, when a small water treatment plant was built in Lake Emdrup.

Initially large amounts of junk were removed from the lakes, including as many as 500 bicycles. Then more than 32 tonnes of coarse fish including roach and bream were fished out of the lakes, and young predatory pike were introduced. Suitable habitats were also created in the lake to provide suitable shelter and spawning areas. Today almost half of the lakes' fish are of predatory species, and the introduced pike and the lakes' natural perch populations keep roach and bream stocks under control. This biomanipulation has had favourable impacts, at least in the short term.

When the water in Peblinge Sø and Sortedamss $\varnothing$ became clear enough later in 2002, submerged plants and bottom flora were introduced in six locations. Two small islands were also created in Sortedamss $\varnothing$ to provide nesting sites for water birds. A colony of cormorants has occupied one of the islands, and they are also used by migrating and wintering ducks.

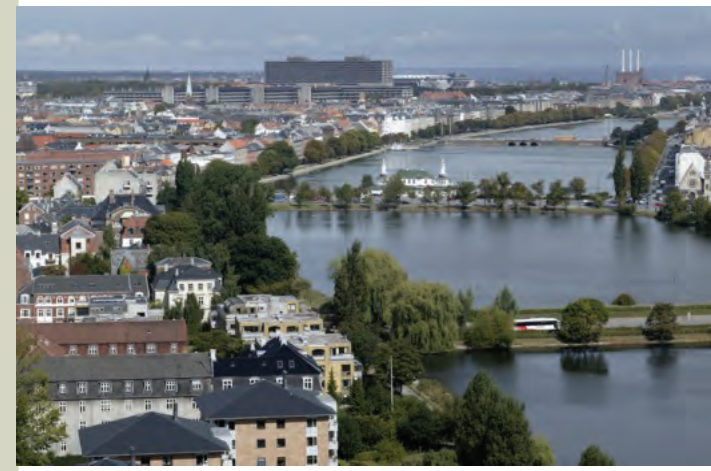

The lakes in Copenhagen are again in good condition, to the enjoyment of local people and visitors. Photo: Mikkel Østergaard/Scanpix. 


\section{Successful management and restoration schemes}

Inland waters affected by eutrophication and acidification can be effectively rehabilitated, and there are several examples of successful restoration schemes from around the Nordic region. Adding lime to water bodies can restore their natural acidity levels, since lime neutralises acidity in the water and also binds aluminum and other toxic metals. The harmful effects of eutrophication can be alleviated through oxygenation, the removal of vegetation from overgrown shores, or biomanipulation schemes involving selective fishing to remove coarse fish and introductions of predatory fish.

\section{Lake Vesijärvi - from algal soup to recreational amenity}

Lake Vesijärvi used to be one of Finland's most polluted lakes, but thanks to careful restoration it is today enjoyed by tens of thousands of people. Back in the 1960 s and 1970s the lake was often clogged up with blooms of blue-green algae, due to severe pollution with sewage and industrial effluent. Algal blooms continued into the 1980 s, even though releases of untreated wastewater ended in 1976, and the lake was oxygenated during the years 1978-84 to speed its ecological recovery. The reason behind this persistent problem was found to be the lake's extremely abundant populations of roach and smelt. By feeding on zooplankton these fish created good conditions for the proliferation of bluegreen algae. In 1987 a project was set up by several organisations and institutions to rescue the lake, aiming to make it suitable for fishing and other recreational activities again.

This project became Finland's first biomanipulation scheme. Targeted largescale fishing led to catches of more than a thousand tonnes of roach and smelt, and pike-perch were introduced into the lake to strengthen populations of predatory fish. Overgrown pike spawning areas were cleared of vegetation. Efforts to reduce nutrient inputs also continued, with storm water channelled into sewerage systems, and buffer zones established in agricultural areas. These measures began to bear fruit in the early 1990s. Blue-green algae vanished, water transparency doubled, and submerged plants began to recover. The introduced pike-perch have formed a naturally reproducing population, while whitefish, trout, vendace and large perch have returned to the lake.

Lake Vesijärvi was not able to recover completely without continuous management, however, and in the early 2000 s blue-green algae was observed again. Research efforts and management measures were stepped up, with new focuses on the treatment of wastewater from dispersed settlements and measures to combat diffuse nutrient inputs originating from farmland. Volunteers, staff from job creation schemes and fishing experts are working together to continue reducing stocks of coarse fish, and oxygenation of the lake will also be initiated again.

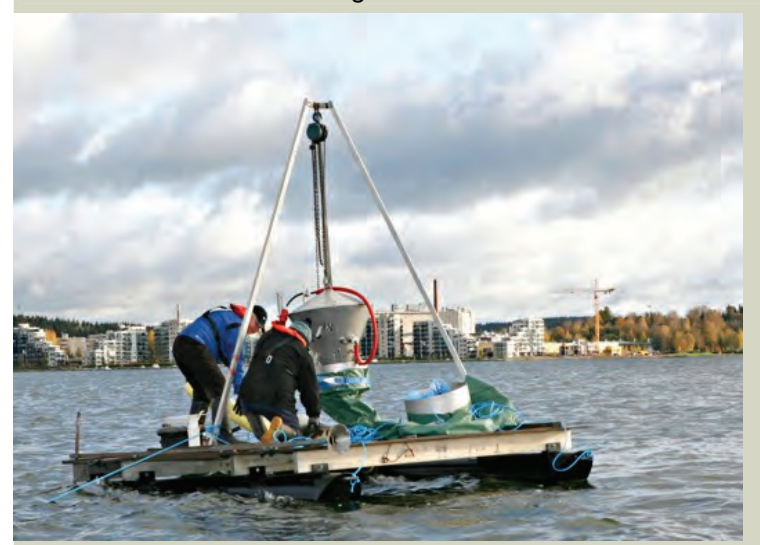

Vesijärvi is Finland's largest successfully restored eutrophicated lake, and also one of the largest in Europe. The project's outcomes and the role of local collaboration make it a good example to follow both in Finland and internationally. More than a hundred similar restoration projects have already been launched elsewhere in Finland.

An oxygen pump is being installed in Vesijärvi. The pump will not be visible from the surface, as only a buoy will be above the surface. Photo: ESS/Leena Liukkonen.

All references are listed on the homepage of the fact sheet: www.environment.fi/nordicnature $>$ Fact sheets $>$ Restoring inland waters

\section{Salmon rescued in Sweden and Norway}

In Sweden and Norway the harmful impacts of acidification have been combated extensively by liming water bodies. Sweden's liming programme is the largest of its kind anywhere in the world. Almost 9,000 water bodies have already been treated by adding lime directly into the water or into surrounding wetlands.

Acidification commenced in Norway in the $19^{\text {th }}$ century, and accelerated until the 1970s. It became apparent in 1925 that increased acidity was killing off fish, but the connection with airborne acidifying pollution was only recognised in the 1950s. The negative impacts on fish stocks and biodiversity worsened as acidification continued. Widespread liming commenced in the mid 1980s, with the aim of improving water quality to enable viable salmon populations to be restored. Salmon stocks have now successfully been restored through introductions in many rivers, and liming has also helped to increase natural reproduction rates among wild salmon.

In the 1970s acidification resulted in the steep decline of salmon in the River Fylleån in Sweden, and at the beginning of the 1980 s they nearly vanished altogether. Other factors contributing to their decline included overfishing, the pollution of the river with effluent, and constructions that hindered the migration of salmon. But measures including the liming of the river since 1982 have enabled salmon to reproduce in the river again, and their densities have grown since the mid 1980s. The species diversity of bottom-dwelling animals including insects, crustaceans, gastropods and shellfish has doubled over the period 1982-2004. The river is now limed continuously, and lime is also added to lakes near its sources and to a wetland along one of its tributaries.

Liming can lead to positive outcomes for salmonids, but impacts are only temporary and localised. To achieve the desired results, lime must be added to water bodies regularly and continuously. The only real long-term solution to acidification is to keep on reducing emissions of acidifying airborne pollutants.

Number/ Salmon density in the River Fylleån $100 \mathrm{~m}^{2}$

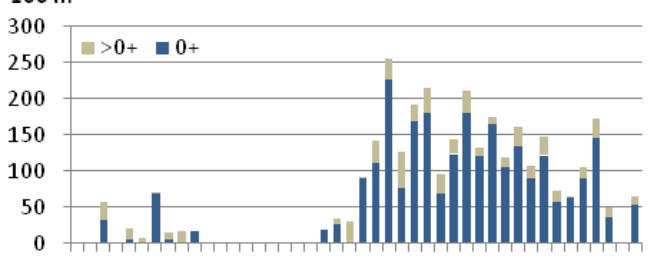

196519701975198019851990199520002005

Densities of salmon populations in the River Fylleån at Tolarp ( $0+=$ fish less than one year old; $>0+=$ older fish). Liming commenced in 1982, when also a metallurgical facility that had formerly discharged effluent into the river was closed down. In 1986 a salmon ladder was opened up to enable fish to by-pass a mill at Tullgren. Source: Naturvårdsverket.

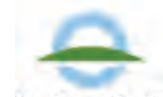

S Y K E

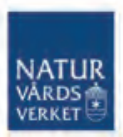

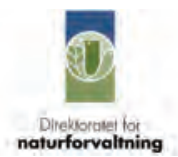

MILJØMINISTERIET

By-og Landskabsstyrelsen

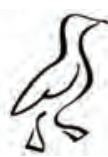

Grønlands Hjemmestyre 


\section{Local contributions to halt the loss of biodiversity}

The 2010 Biodiversity Target is a global nature conservation goal. The aim is to halt the loss of biodiversity by the year 2010 .

Measures need to be taken in all sectors of society for this target to be reached. Local communities, represented by the municipalities play a central role, since they are the authorities responsible for land use planning, and since they control much of the biological diversity. Local communities are also the natural arena for mobilising and engaging the public.

A Nordic project was launched in 2006, setting up a network of Nordic municipalities to implement specific projects relevant to the 2010 target The network is intended to form a forum where the local authorities can exchange their experiences, and to demonstrate the necessity of local efforts to reach the 2010 target. The network currently consists of 14 municipalities. The projects range from restoration, nature conservation, the use of municipal plans as instruments and combating alien species to safeguarding species through management. Key features of most of the projects include local participation and providing information on biodiversity.

In order to reach the 2010 target, the municipalities in the network are obliged to conduct projects relevant to the 2010 target. The results of these projects are to be measurable. The municipalities will submit final reports before the end of 2009 and set up websites to publicise information on the projects. If possible, they should also sign the Countdown 2010 declaration.

Hammerfest has placed artificial reefs in the sea to restore marine habitats that have been destroyed. Pipes made of recycled plastic have been fixed to concrete cylinders. These structures offer shelter for fish fry and give seaweed improved living conditions. The aim is to replace the kelp forest that has been excessively grazed by sea urchins.

Stjørdal will employ land use planning to safeguard biodiversity, particularly in shoreline areas where waders and ducks rest. The municipality is supporting a local association, "Færbøgda i lag", which is maintaining a local interest for traditional haymaking. Stjørdal's meadows have many species of plants including harebell, oxeye daisy, sweet vernal-grass, and rarer plants like quaking-grass and greater butterfly orchid.

Trondheim is ensuring that streams near the city centre will be in a good ecological state. The city has an abundance of game animals within its boundaries, but the habitats of many of these species are threatened by fragmentation. The capercaillie is being used as an indicator species for the desired state of the woodland in Bymarka. Systematic landscape management in the Lian-Solem area will safeguard the historical cultural landscape.

Örebro has converted a former landfill and a former oil port into a nature reserve and a lakeland park. More species of birds have since been observed here. The restored area amounts to 600 hectares (14 826 acres) and is very popular with local people and visitors alike.

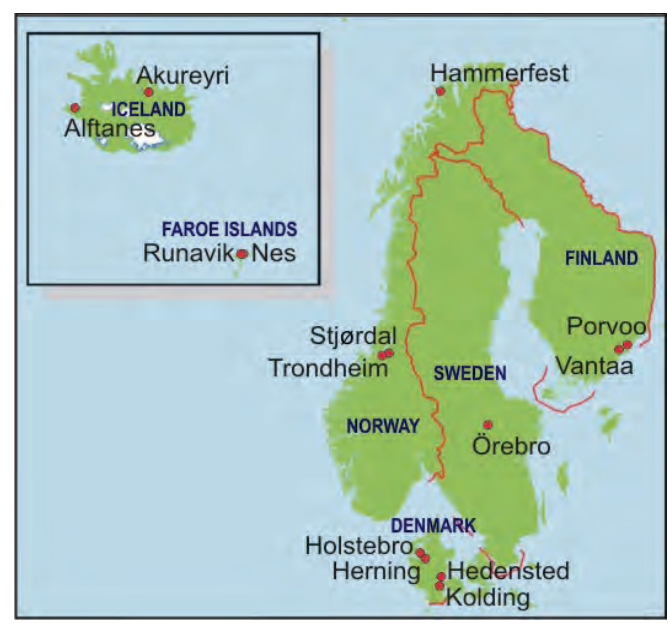

Map of the participating municipalities.

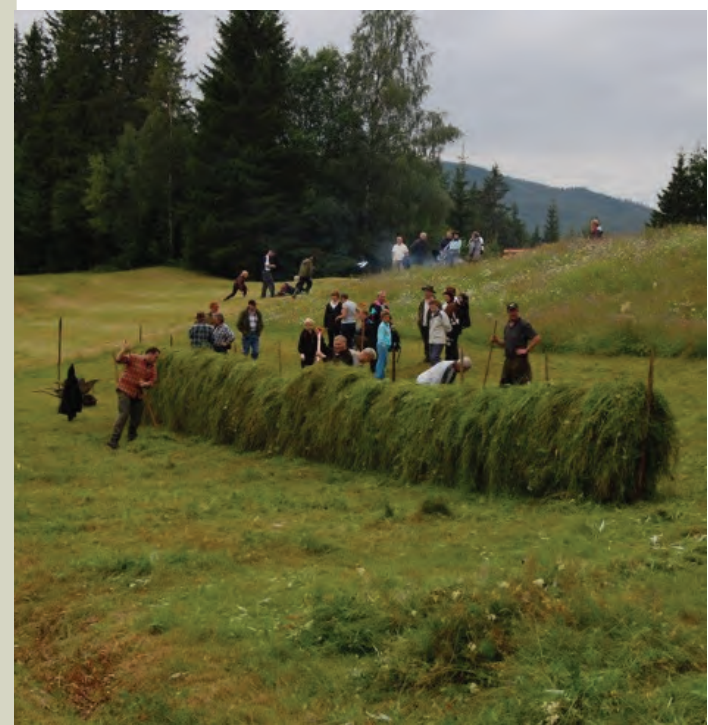

Haymaking in one of the species rich meadows in Stjørdal. Photo: Ingvild Kalland. 
Hedensted will ensure sustainable forestry by certifying the forests flanking Vejle Fjord. An area of wetland covering 85 hectares (ca. 210 acres) will be formed, including a 25-ha (61.7 acres) lake. More varied physical conditions in the River Skjold will have spin-off benefits for sea trout, aquatic insects, ducks and waders. Grazing in open environments will safeguard botanically valuable sites.

Herning is drawing up an environmental policy that will safeguard existing natural assets and create large, continuous natural areas. An action plan for salmon in the River Skjern system will also improve the conditions for several other species of fish. The salmon is a good indicator species, since it makes high demands on the quality of the environment. Herning has also prioritised measures to combat climate change, since it poses a threat to biodiversity. The municipality has initiated several measures that will save energy.

Holstebro has created 55 ponds to improve conditions for great crested newts, moor frogs, common spadefoot toads and natterjack toads. Grazing has been re-introduced to safeguard open landscapes, so that plants which require plenty of light will thrive, and to encourage a rich diversity of insects and birds. Dams are being demolished in rivers to make them more accessible for salmon, trout and lampreys.

Kolding will improve the state of the water in Skærsjø, a lake famed for its water lobelias. The species water lobelia, lake quillwort and shoreweed, are all present and all of them thrive best in clear water that is poor in nutrients. The physical conditions in the River Âkær are being improved by constructing more meanders and placing rocks and gravel along a $17 \mathrm{~km}$ long stretch. Wetlands flanking the Åkær are also being restored.

In the Faroe Islands, the neighbouring municipalities of Nes and Runavik are growing centres of population. Traffic in the area surrounding the lake Toftavatn will be restricted to safeguard areas of heather and the birdlife there. A key feature of this project is providing information on biodiversity.

Porvoo will set up a national urban park embracing a great variety of natural habitats and valuable cultural environments. Maren's meadow, a former pastureland, is one of the most important parts of the proposed park. Tree clearance and grazing will prevent the pasture from becoming overgrown.

Vantaa has a long tradition of nature conservation, and $6 \%$ of its total area is protected. In addition to these protected areas, there are areas of special importance for biodiversity, known as "LUO" areas, that are especially valuable on the local level. Special management measures must be introduced in these areas to preserve their biodiversity.

Akureyri is combating alien species on Hrisey. Cow parsley, lupin and garden angelica now cover $11-13 \%$ of the island, and seeds are being sown from native Icelandic flora to restore areas with characteristic heather species. The same procedure will enable an area of 30 hectares (ca. 74 acres) at a former landfill site in the valley of Glerárdalur to fit naturally into its surroundings. A former wetland at Naustaborgir is also being restored to provide habitat for birds.

Alftanes is improving habitats for birds by restoring former wetlands close to two lakes, Kasthúsatjörn and Pvottatjörn. An undeveloped area surrounding the official home of the President of Iceland will also help these two areas to function better.

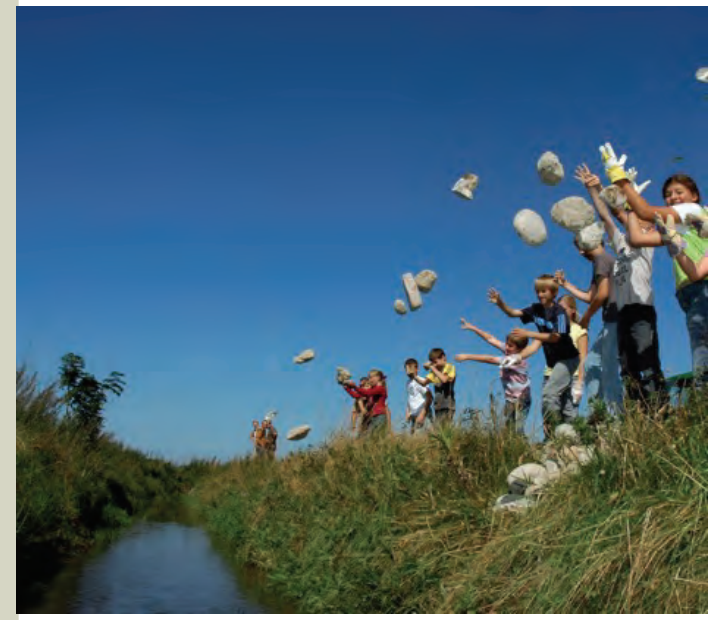

Children take part in the work to safeguard biodiversity by throwing rocks into the River Âkær in Kolding. Photo: Kaare Manniche Ebert.

This Nordic project demonstrates the importance of nature conservation on a local scale, and also the key role of municipalities as the land use planning authorities. The local projects described above all show how measures taken to preserve biodiversity can be worthwhile.

The project will end in 2010 . The final report on the project will demonstrate the necessity of local contributions for reaching the 2010 target. The results can motivate other municipalities, so that Nordic municipalities can set an example in local work for biological diversity. The participating municipalities will of course continue their work to conserve biodiversity even after the year 2010. Long term monitoring in the participating municipalities has also been discussed.

The homepage of the project at the Norwegian Directorate for Nature Management: www.dirnat.no/2010-malet

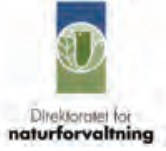

\section{MILJØMINISTERIET} By-og Landskabsstyrelsen

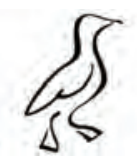

Grønlands Hjemmestyre 


\section{Traditional agricultural biotopes vanishing in the Nordic Countries}

Biotopes formed by traditional agricultural practices such as mowing and grazing have almost vanished across the Nordic Countries, and many of their characteristic species have disappeared or are threatened. Habitat changes induced by land use changes are the greatest threat to biodiversity in the Nordic Countries and globally. This is true also for traditional agricultural biotopes and their typical species.

\section{Biotopes worth preserving}

Nordic environments originally had relatively few naturally open areas, such as shore, mountain and rock meadows. But through history people have shaped landscapes in similar ways across the Nordic region with their traditional farming practices - mowing meadows and grazing their livestock in pastures, thus creating open vegetation types and landscapes that are ideal habitats for plants and insects that thrive on light, warmth and open landscapes. This has resulted in highly diverse traditional agricultural biotopes, including open meadows and heaths; wooded pollard, alder and coppice meadows, as well as wooded pastures, grazed woodlands and woodland habitats created by slash and burn farming. In Norway, there is also a special open landscape type that has been formed by mountain dairy farming on mountain slopes, where cattle were grazed in summertime.

Meadows may have been most widespread in the $19^{\text {th }}$ century, when Finland alone had meadows with a total area of 1.6 million hectares, declining to half of this extent by the 1920s. Meadows and pastures were then ploughed up to create crop fields, left to be reclaimed by forest, or actively reforested. The mechanization of agriculture and the use of artificial fertilisers almost completely wiped out such habitats. The species diversity of farmland narrowed due to the end of its diverse use. The golden age of traditional agricultural landscapes ended in the 1950s and 60s.

Most of the species associated with traditional agricultural biotopes arrived in the Nordic region after the Ice Age, when steppe-like conditions prevailed in the newly exposed lands. As forests gradually spread, these species clung on in refuges such as rock outcrops, mires, esker ridges, forests, fells, and along the shores of the Baltic Sea, until people created more habitats for them in meadows and pastures. The species of unploughed and unfertilized meadows and pastures are now threatened with extinction, unless their habitats can be purposefully maintained, or new habitats can be found for them.

\section{Land use changes threatening meadows and pastures}

Traditional agricultural biotopes are the most species-rich habitats in North Europe. Their last scattered remnants are most threatened by the end of livestock grazing, the overgrowth of former pastures, and eutrophication caused by artificial fertilisers. The best land is today mostly used for intensive monoculture or building developments. Forestry also competes with agriculture for land, and many former pastures and meadows have been afforested.

In Denmark, many meadows have been converted to crop fields, or simply abandoned. Meadows and other open biotopes are today protected against clearance by conservation legislation. In many cases these areas are no longer traditionally mown and grazed, however, as this requires continuous work. The most varied cultural landscapes of Northern Europe are found in Norway, where most of them remain intact. However, the total area of mown lands declined in Norway by more than $90 \%$ during the $20^{\text {th }}$ century. Over Europe as a whole, meadows have shrunk to just $1 \%$ of their original size. Sweden has the largest remaining areas, with around 200,000 hectares left, compared to Finland where only a few thousand hectares of meadows remain. The Faroe Islands, Iceland and Greenland do not have the same kinds of traditional meadow and pasture biotopes found in the rest of the Nordic region.

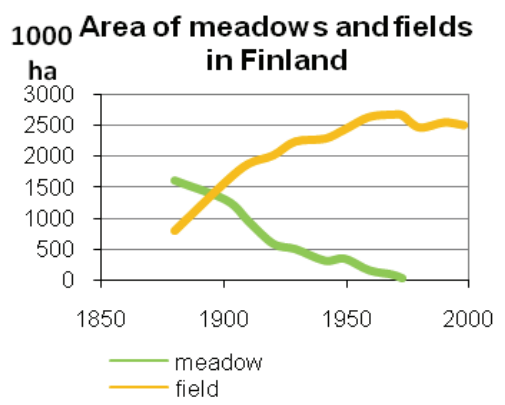

The area of meadows in Finland has declined rapidly since the end of the 19th century, at the same time as the area of crop fields has increased, partly because meadows have been converted to arable land. The same trend can be seen also in Sweden and Denmark. Source: Statistics Finland 2001: Finnish statistical yearbook 2001. Soininen, A. 1974: Vanha maataloutemme. Maatalous ja maatalousväestö Suomessa perinnäisen maatalouden loppukaudella 1720-luvulta 1870-Iuvulle. - Historiallisia tutkimuksia 96:1-459.

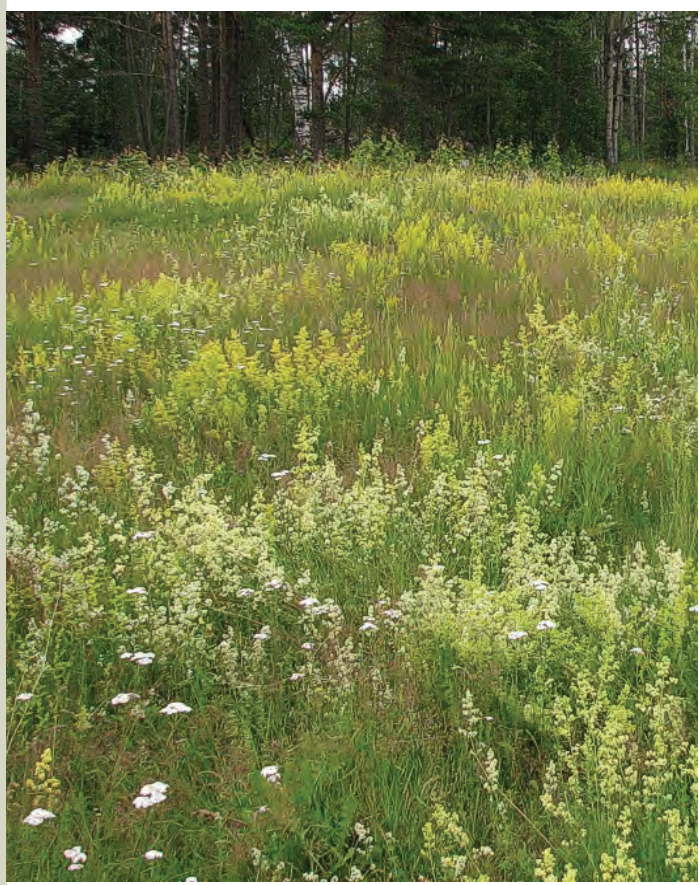

The yellow bedstraw (Galium verum) is found in Finnish traditional agricultural biotopes, where it is threatened by the decline of its habitats and by the alien species whitish bedstraw (Galium album), with which it crossbreeds to form hybrid yellow bedstraw (Galium $\times$ pomeracium). Both the whitish bedstraw and the hybrid yellow bedstraw thrive better in overgrowing and eutrophic sites than the yellow bedstraw, and they threaten to wipe it out through cross-breeding. The illustration features yellow bedstraw together with whitish bedstraw and the light yellow hybrid bedstraw. Photo: Sonja Forss. 


\section{Careful management can benefit many species}

Traditional agricultural biotopes are among the most threatened habitats in the Nordic region. Meadows, pastures and woodland habitats created by slash and burn farming can today only be found in small patches. Their rich flora provides suitable conditions for a wide range of invertebrates, particularly butterflies, hymenoptera and beetles. Bird life is rich especially in pollard meadows and wooded pastures. Traditional agricultural biotopes additionally have their own characteristic species, including dung beetles, fungi and mosses, and plants associated with pollards. The rapid decline of these biotopes has put many such species under threat. The remaining areas must be carefully managed and kept open to ensure that their landscapes and species will survive for future generations.

The main aim of management is to remove the masses of vegetation that develop during each growing season, together with the nutrients they contain, through grazing or mowing. This prevents nutrient enrichment and the formation of soil litter that would inhibit the growth of meadow species. In wooded biotopes, another goal is to preserve their characteristic mosaic-like mixture of patches of woodland and meadowland. Older individual trees should also be cherished.

Grazing is a natural way to manage such habitats. In wooded areas, grazing is virtually the only way to do this. Pollard meadows, however, should also be mown occasionally to maintain their vegetation. Increasing the availability of light and warmth and reducing nutrient levels in soils will favour the meadow plants adapted to such conditions. Livestock also trample and expose the soil, facilitating the germination of meadow plant seeds. Mowing is another traditional practice that can be continued, preferably using traditional tools like scythes and sickles. Mowing reduces the competition from the larger plants that benefit from nutrient-rich conditions, favouring plants that thrive in sunlit sites.

The difference between the impacts of grazing animals and mowing is that animals graze unevenly, selectively and gradually, whereas mowing removes all the vegetation at the same time. Grazing livestock may increase the nutrient content of soils in places, if additional fodder is provided for them. The timing of mowing or grazing is important, since plants should have time to flower and go to seed, and as little decaying vegetation as possible should be left to add nutrients to the biotopes. Allowing animals to graze in areas that have already been mown can further promote the development of diverse flora and fauna.

To preserve the species of traditional agricultural biotopes, it is vital to support the continuation of the related farming practices. Support for such management can be channeled through the EU agri-environmental subsidies scheme and the EU LIFE Nature Programme, for instance.

It can be hard to continue traditional farming practices like mowing by hand, which is labour-intensive. In Finland, biotopes are often managed by employment scheme workers or volunteers from environmental organisations. In Denmark, such work is also often done by volunteers. Where grazing is concerned, the lack of suitable livestock is often the limiting factor. In both Finland and Denmark, grazing associations have been set up to loan out livestock for landscape management purposes.

\section{A rosy future possible for traditional farmland species}

There can be no return to the days of traditional livestock farming, and farmlands free of pesticides or artificial fertilisers and broken up by open ditches. But if people become more aware of the value of endangered traditional agricultural biotopes, their future could become brighter. There is a desire to preserve such vanishing landscapes, which are some of our most diverse but most threatened biotopes. They are also part of our common history. They were created by the interaction between man and nature, and are worth preserving, since they provide habitats for almost all of the flora, fauna and fungi of the Nordic region.

By enhancing the management of our remaining traditional agricultural biotopes, it will be possible to preserve their biodiversity. The survival of such biotopes in the Nordic region and the future prospects for their species are dependent on the creation of a suitable network of regularly managed traditional agricultural biotopes. Only time will tell whether we have set about managing the last surviving examples of these habitats soon enough to ensure their future preservation.

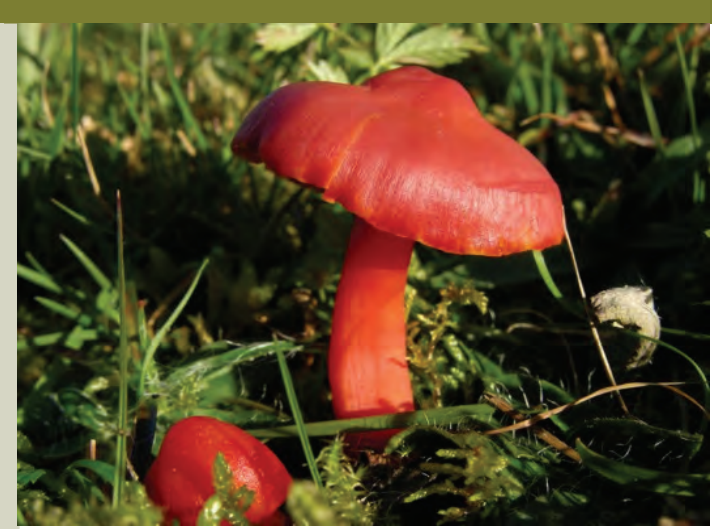

Pasture fungi form a threatened species group living in unfertilized pastures and meadows, in hygrocybe grasslands. Up to $20-25 \%$ of all known fungi in Norway and Sweden occur mainly in traditional agricultural biotopes, and can be counted as pasture fungi.

Scandinavia has diverse pasture fungi species and is responsible for protecting them. The splendid wax-cap (Hygrocybe splendidissima), illustrated, occurs in unfertilized pastures. It is threatened by overgrowth and the use of fertilizers. This species is classified as near threatened in Sweden and Norway, and as endangered in Denmark. It does not occur in Finland. Photo: J.C. Schou/Biopix.

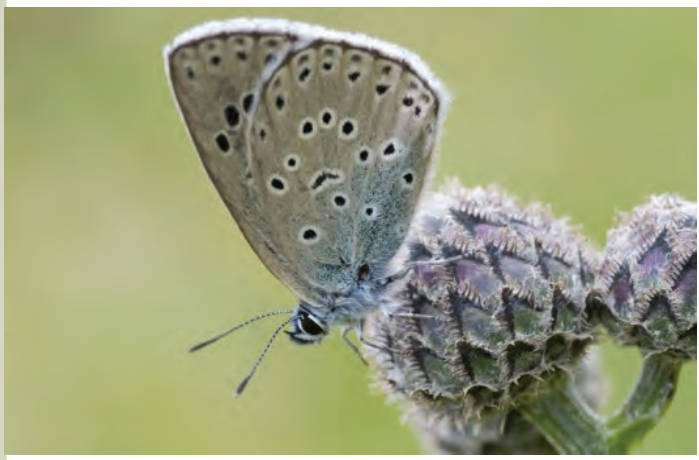

The large blue (Maculinea arion) is one of the most threatened butterflies in the Nordic Countries. It is very demanding about its habitat, and dependent on certain host species for its development. The female lays her eggs on the flowers of wild thyme (Thymus) or marjoram (Origanum vulgare). The larvae then feed on the flowers for a few weeks before their host ant (Myrmica) takes them to its nest, where the larvae live as nest parasites and then overwinter and pupate. The large blue is thus dependent on its host plants and ants, as well as open sun-exposed habitats, which are declining at an alarming rate. The large blue only occurs in about ten locations in Sweden, and two sites in each of Finland and Denmark.

Photo: Niels Poul Dreyer/Biofoto.

All references are listed on the homepage of the fact sheet: www.environment.fi/nordicnature > Fact sheets > Traditional agricultural biotopes vanishing.

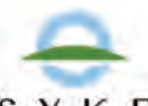

$S Y K E$

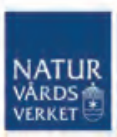

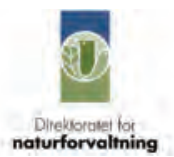

MILJØMINISTERIET

By-og Landskabsstyrelsen

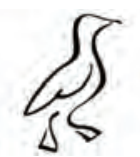

Grønlands Hjemmestyre 


\section{Europe's national parks celebrate a century of conservation}

National parks represent nature at its best, and form a vital part of our natural heritage. These national treasures must be preserved for the sake of nature and for future generations. Their natural attractions and recreational facilities are freely accessible to everyone, but they would not survive without well-planned protective measures.

The concept of national parks was dreamed up in the US in the 1870s as the population spread westwards, and the new settlers resolved to preserve the unique natural features of the Yellowstone region as common property. The world's first national park was established at Yellowstone in 1872. Australia, Canada and New Zealand soon followed suit setting up their own parks. Sweden founded Europe's first national parks a century ago in 1909, and the idea spread rapidly around the world after the Second World War.

The Nordic explorer A. E. Nordenskiöld first sparked a debate about Nordic national parks in 1880 , and nature reserves began to be set up around the region from the turn of the century. Sweden led the way, enacting its first nature conservation legislation in 1909, establishing the country's first national parks to protect five areas of arctic fell in the north, an area of pristine oldgrowth forest, two areas with rich cultural landscapes, and part of the island of Gotska Sandön.

Until the 1960s the main idea behind nature conservation was based on national romanticism, and a desire to preserve beautiful natural landscapes for future generations. Areas were mainly selected for protection for aesthetic reasons or as attractions for tourism, so the earlier networks of national parks were not designed to meet the same objectives related to preserving natural values that national parks are expected to achieve today.

\section{Conservation values of national parks}

National parks' primary purpose today is to safeguard biodiversity. They should represent typical examples of each country's nature, as well as unique natural features that are nationally and internationally valuable. They also often incorporate national landscapes and natural attractions, and provide valuable settings for recreational activities on the terms of nature conservation.

Nature conservation today aims to protect entire ecosystems or coherent biogeographical areas within national parks, instead of smaller and more isolated areas, which in spite of their valuable features cannot effectively ensure the survival of populations and a wide range of biodiversity. Smaller areas can be protected by setting up other types of nature reserves. Networks of national parks and other nature reserves should preserve part of every habitat type found in each country, and prevent species extinctions. Suitably extensive networks can safeguard flora and fauna of each country's characteristic habitats, as well as the structures and functions of entire ecosystems.

In the Nordic Countries there is still a lot of scope for further conservation Perhaps the world's most important conservation target, set out in the Caring for the Earth strategy, approved in 1991 by the World Conservation Union (IUCN), the UN Environment Programme (UNEP) and the WWF, states that protected areas should cover at least $10 \%$ of each habitat type. Forests are also specifically mentioned in the strategy, together with a specific target to preserve $10 \%$ of old-growth forests. An interim target of the Nordic Council of Ministers is to protect $5 \%$ of forestland by 2010 .

\section{Nordic national parks}

The largest areas of Sweden, Norway and Finland protected within national parks lie in the north parts of the countries or in the fell regions, so these countries' national park networks do not protect all habitat types evenly.

Protected areas in other regions tend to be small and fragmented, and the $10 \%$
National parks are protected areas within the IUCN's protected area category II, managed mainly for ecosystem protection and recreation. They contain natural areas of land and/or sea, designated to (a) protect the ecological integrity of one or more ecosystems for present and future generations, (b) exclude exploitation or occupation inimical to the purposes of their designation, and (c) provide a foundation for spiritual, scientific, educational, recreational and visitor opportunities, all of which must be environmentally and culturally compatible. They should have a minimum size of 1,000 ha.

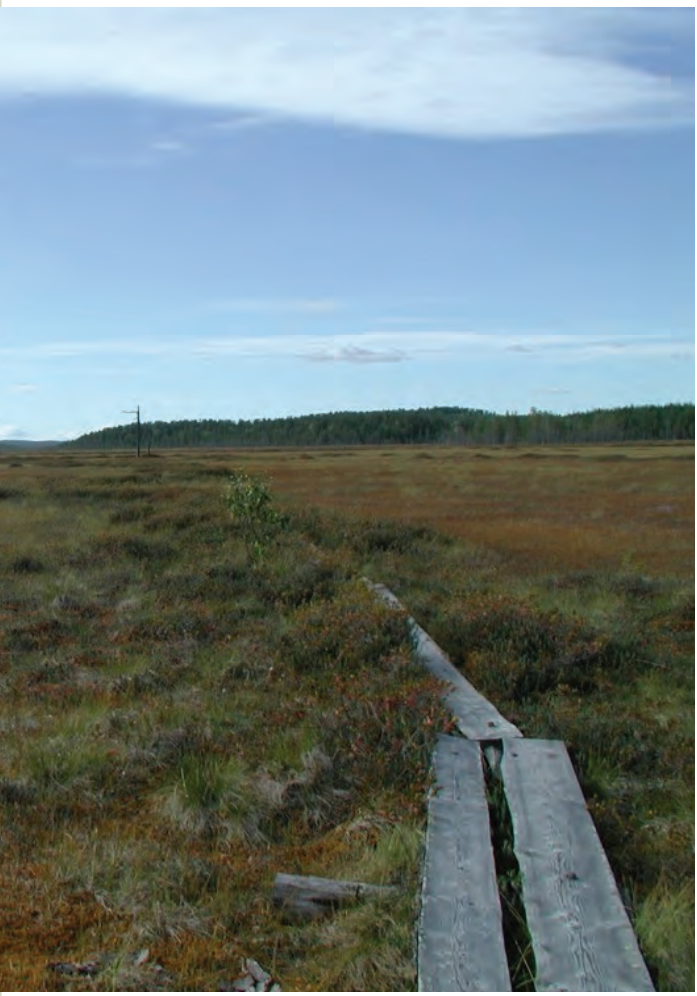

Patvinsuo National Park in Eastern Finland was established in 1982, and it is internationally importan as a mire conservation and research area with oldgrowth forests and waterways. In this secluded wild forest and mire area there is a vital bear population. Photo: Marja Pylvänäinen. 
conservation target is not met for biotopes characteristic of these regions. The treeless fell areas and forested fells also are less productive for forestry and agriculture, so it has been easier to reserve them for conservation. This leads to an unfortunate general trend that protected areas tend to be fewer and further between in correlation with the increasing productivity of the land. Most Nordic national parks and other protected areas also belong to the EU's Natura 2000 network of protected areas.

Sweden has a total of 28 national parks. The Swedish national parks plan proposes many new areas for protection, aiming to enhance the network's representativeness. Sweden's $29^{\text {th }}$ national park, Koster, to be established on $29^{\text {th }}$ September 2009, will be the country's first marine park. Norway has 31 national parks, and additionaly 7 in Svalbard. Norway's $32^{\text {nd }}$ national park will be established in August 2009. Four of Finland's 35 national parks are in marine areas.

Denmark established its first national park, Thy, to meet IUCN criteria in 2008 in northwestern Jutland, and four more parks are planned. Greenland has only one national park, but it is the world's largest and most northerly park. Established in 1974 and expanded in 1988, it covers almost a million square kilometres. Most of this area consists of a continental ice sheet, but it also includes a long coastal strip. The Faroe Islands have no national parks, but the first one is planned. Iceland has three parks, the first of which was established in 1928 .

The Nordic Countries' national parks are in a strong position, but in practice they do not always completely protect nature against exploitation. There are differences in the strictness of protection in different countries and in some national parks exemptions have been granted to permit hydropower developments, road construction, mining activities and hunting.

The Nordic Countries have international responsibility to protect biotopes that are particularly characteristic of the region, including archipelagoes, land uplift coasts, fracture valley landscapes, wetlands, natural forests, traditional farmland, alvars, areas used for slash-and-burn farming, unharnessed rivers, eskers and moraine ridges, active volcanic areas and geysers, glacial outwash plains, Lake Mývatn and the spring-fed rivers of Iceland, seabird islands, Baltic marine habitats, the dune landscapes of Jutland, and the Wadden Sea. National parks are an important way to protect these uniquely Nordic natural features.

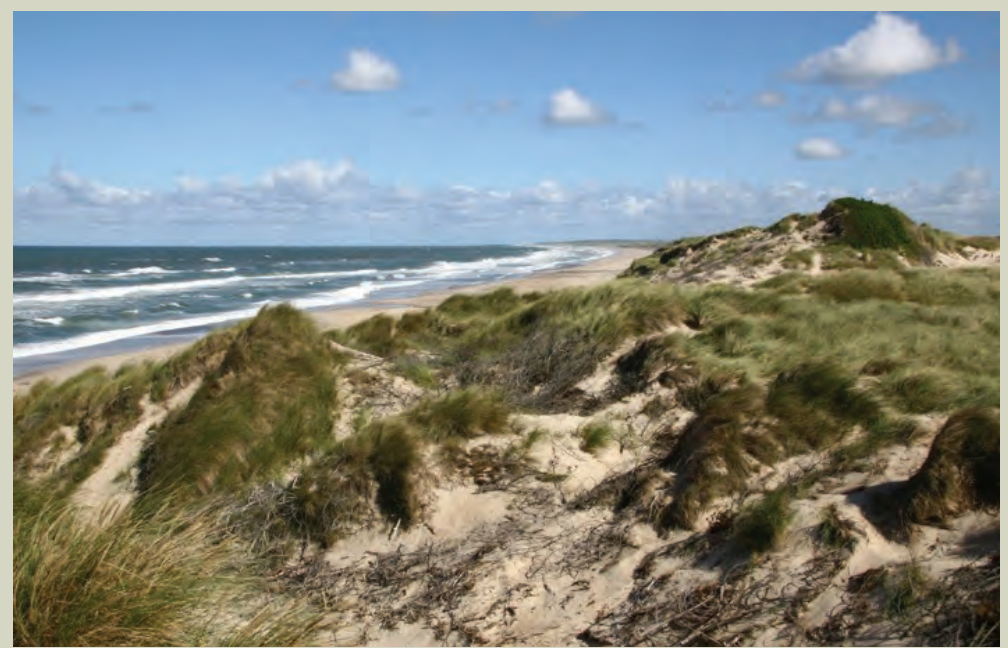

The outermost dunes in the Hanstholm wildlife reserve in Denmark's first national park, Thy. Photo: Ib Nord Nielsen.

References on the home page of the fact sheet: www.environment.fi/nordicnature $>$ Fact sheets $>$ National parks

\section{Parks as recreational amenities}

Although national parks' primary function is to safeguard biodiversity and natural processes in settings unaffected by human impacts, in some cases their value is specifically a consequence of traditional land use practices such as reindeer herding. Whenever parks are established, their unique landscapes and local history must be considered alongside their biological values. It is also important to ensure that everyone has the opportunity to enjoy our shared natural heritage.

Nordic national parks are open to all visitors free of charge, and many have visitor centres, trails, camp fire sites, shelters, cabins and other facilities. They strive to serve as amenities for outdoor activities and recreation, without putting their nature conservation goals at risk. Their visitor centres aim to provide guidance and information, and increase public awareness of the importance of biodiversity.

Widespread interest in unspoilt nature, reflected in increasing nature tourism, could ultimately also endanger national parks' natural values. Incoming traffic and high visitor numbers can put a burden on their natural features, though local service providers clearly have an incentive to preserve the natural state of the areas where they operate so as to attract tourists in future. Tourism can also provide local communities with income, which may compensate for any losses of income caused by the protection of areas that were previously exploited commercially.

\section{Other protected areas complement networks of national parks}

Strict nature reserves, wilderness areas, natural monuments, species or habitat management areas, landscape conservation areas and areas defined for the management and conservation of natural resources form together with national parks an extensive network if protected areas through the Nordic Countries, which is further complemented by the EU's Natura 2000 network and private protected areas. Conservation is enforced through acts, decrees, administrative decisions and directives.

The "European Day of Parks" is celebrated every $24^{\text {th }}$ May, under an initiative of the EUROPARC organisation - the largest and most important federation of European protected areas that encompasses national parks, regional parks, strict nature reserves and biosphere reserves in 39 countries. It aims to protect their unique and diverse nature. The federation's 500 member organisations work to cherish Europe's "green jewels" as our common natural and cultural heritage.

Finnish Environment Institute SYKE - www.environment.fi/nordicnature

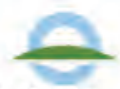

S Y K E
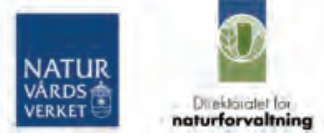

MILJØMINISTERIET By-og Landskabsstyrelsen

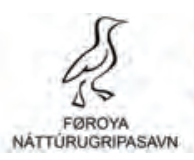

Gronlands Selvstyre

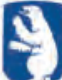




\section{Threats to biodiversity in the Nordic Countries}

Biodiversity - which is vital for life on Earth - has declined alarmingly over the last century. The deterioration of species' habitats is the largest single threat to biodiversity both globally, and in the Nordic Countries, where the rate of biodiversity decline is just as rapid as it is worldwide.

Land use changes lead to the loss, shrinking or deterioration of natural habitats. There is less room for biodiversity wherever natural areas are built over or converted to farmland, and wherever open areas become overgrown. The quality of the remaining natural ecosystems may also decline, due to habitat fragmentation, climate change and pollution. Impacts on habitats are directly reflected in species' populations and genetic diversity, often putting the survival of entire species at risk.

Invasive alien species and climate change are the next most serious threats to biodiversity. Many species' populations are also affected by hunting, trapping, gathering and fishing, with its significant by-catches. Pollution additionally alters habitats through eutrophication, acidification and contamination, often seriously affecting species' prospects.

\section{Harmful land use changes}

Our use of the land and exploitation of natural resources have always shaped natural habitats, consequently altering their species assemblages and the interrelationships between species. Land use changes tend to be unfavourable to an area's former flora and fauna - with the exception of the protection of habitats in new nature reserves.

Land use changes result from society's demands for the increasingly intensive commercial exploitation of land and other natural resources. Some of the most harmful processes for biodiversity include the conversion of "unproductive" natural areas such as mires and wetlands into farmland, commercial forests or peat extraction sites, with the help of artificial drainage schemes.

The intensification of agriculture and the abandonment of production in less productive areas have led to the loss of ecologically valuable traditional agricultural biotopes shaped by earlier farming practices. These species-rich habitats have widely become overgrown where traditional grazing and mowing have ended. Many of their characteristic species are now seriously threatened. Such areas have been replaced by large, uniform open fields, fertilised, managed using machines, and drained by concealed ditches. Such landscapes lack the grassy verges, ditches and wooded patches that were rich in species.

Intensive forestry has meanwhile created forest habitats that are more uniform in terms of the ages and species of trees. Natural old-growth forests with their many dead and decaying trees have been disappearing, together with their many typical species. Arctic fell habitats have been altered by overgrazing and the consequent erosion in many places, while elsewhere they have become overgrown where summer pastures are no longer grazed.

Built-up areas and transportation routes are spreading through natural areas and becoming even denser in more populated regions. Forest roads nowadays penetrate deep into remote wild areas in Norway, Sweden and Finland, further fragmenting the last extensive natural environments. Even the most remote locations in Iceland and the Faroe Islands can now be reached by road or sea, and disturbance from visitors and traffic has increased greatly. Species' populations are increasingly cut off from each other, threatening their genetic diversity. Shore habitats change due to new building developments including holiday homes. Increasing nature tourism can worsen noise and other kinds of disturbance, especially from motor vehicles.

Dams and reservoirs have harnessed natural rivers and drowned large areas of land. Oil and gas rigs and wind turbines blemish natural seascapes, just as telecommunications masts spoil wild areas. Mining, quarrying, landfill and

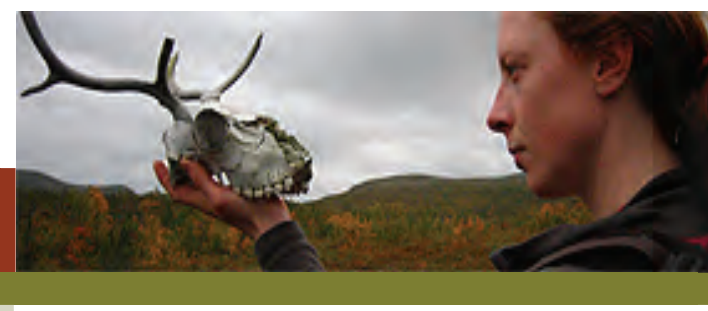

Some threats only have destructive impacts on a local scale, and do not endanger the survival of entire biotopes or species. If a pond that is home to a frog population becomes overgrown due to eutrophication, for instance, frogs may be able to move to another more favourable habitat, as long as suitable pathways are not blocked by fragmentation. It may also be possible to restore habitats to help bring back a lost population - as long as it was not the species' last population. But other changes have much wider impacts on whole biotopes and their characteristic species, as is the case with the effects of climatic warming on tundra habitats and the ecosystems of continental ice sheets and sea ice.

Certain threats may be acute, with their impacts apparent immediately, while others may not become evident for some time. This may depend on the extent of a species' typical territory. Habitat deterioration may have immediate impacts on species that live within a limited range, whereas changes may only be reflected slowly in species that range over extensive territories, e.g. as reduced availability of food.

The impacts of individual threat factors may be limited in themselves, but the combined impacts of several factors could be disastrous. The mechanisms involved are often complex, and it can be hard to differentiate causes from effects.

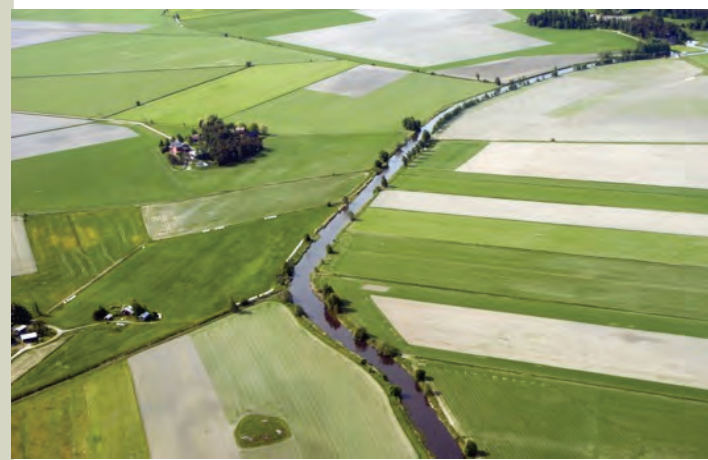

Changes caused by the intensification of agriculture are visible in the landscape. The number of farms is decreasing, and modern farms have larger, more uniform fields, reducing their biodiversity. The landscape pictured is in southwestern Finland. Photo: Riku Lumiaro. 
dumping all destroy habitats. The only remaining truly untouched wild areas in the Nordic Countries are in Svalbard and a few fragmented protected areas.

At least three-quarters of the Nordic Countries' threatened species are at risk due to land use changes. Most of these are species of old-growth forests, traditional agricultural biotopes or natural mires. The impacts of intensification on biodiversity are clearly evident in agriculture and forestry, and measures to address such problems have been initiated. EU subsidies support the mowing and grazing of traditional farmland habitats, for instance. Forestry practices are being softened to consider conservation priorities - for example by leaving decaying wood in the forests. In ditch cleaning and supplementary ditching of peatlands, the impacts on surrounding habitats are now carefully considered Mires, wetlands, traditional agricultural biotopes, springs and other habitats are being restored in many places.

\section{Alien species a real threat}

The spread of invasive alien species is rated as the second greatest threat to biodiversity globally. Non-native species are spreading into new areas increasingly rapidly through human activities as international trade, transportation and travel intensify.

Some aliens eventually become well established, often to the detriment of loca native species. In the Nordic region invaders have become harmful where they out-compete native species for food or territory, increase their populations and disrupt natural ecosystems. They may also bring in parasites and diseases that have unforeseen impacts on local species. New species are likely to spread northwards due to habitat changes induced by climate change. Not all alien species become harmful to native species, however

Once they become established, it is often extremely difficult to eradicate alien species. In seas and inland waters this may be almost impossible. The best way to prevent their arrival and spread is to anticipate problems, and enact effective legislation. Once a species has arrived, steps can still be taken to try to exterminate them, slow their spread, or reduce the harm they cause to local species. The earlier such actions are initiated, the more likely they are to succeed. Publicity and awareness raising measures play a vital role in such work.

\section{Climate change a growing threat}

Climatic warming, increased precipitation and sea level rise can all be expected to affect biodiversity in the Nordic Countries. Climate change mainly results from increases in the amounts of greenhouse gases released into the atmosphere by human activities, and its impacts will depend on future trends in emissions.

These impacts may be particularly disastrous for coastal biotopes and biotopes associated with ice and permafrost, and their typical species.

The distributions of biotopes and species will change considerably, with some species even vanishing altogether. Dramatic changes are particularly predicted for arctic regions. Some species will not be able to adapt to habitat changes or shift their distributions accordingly. As the climate warms, arctic tundra and fell habitats will change, and species will run out of habitat as the tree line shifts ever further northwards and upwards in mountainous regions. The waters of the Arctic Ocean ultimately block the northward spread of species. Biotopes associated with permafrost conditions may disappear completely. If the permanently frozen icy cores of palsa mires thaw, for instance, we will lose these unique habitats for ever.

The arctic tundra biotopes that dominate much of Greenland will vanish as the climate warms. Continental ice sheets will shrink, as will the sea ice that is vital to the polar bears. Shorter, milder winters are already causing problems for seals that raise their pups in dens built on the ice. This problem is particularly a concern for the endangered Saimaa ringed seals in Finland. New species may arrive in the Nordic Countries from the south as conditions become favourable to them. Climatic warming can also accelerate the overgrowth of traditional agricultural biotopes, and help non-native species to survive and spread.

All references are listed on the home page of the fact sheet

www.environment.fi/nordicnature $>$ Fact sheets $>$ Threats to biodiversity in the Nordic Countries
Exploitation of fish, whale and game stocks

Like the land itself, the populations of many plant and animal species have also been exploited intensively, with many species consequently becoming endangered. Stocks of many fish, crustaceans, seals and whales have been exploited beyond their capacity to recover. International quotas and protective measures have been defined in an attempt to ensure their survival, but such quotas are often so high that stocks are still overexploited in practice.

People have hunted since time immemorial, and many populations of game species and large carnivores have been seriously endangered. Modern hunting controls and quotas aim to ensure that their populations are managed sustainably, also striving to minimise damage to domestic livestock. But the persecution of large carnivores has not totally ended in the Nordic Countries, and large carnivores are still hunted illegally.

\section{Harmful chemicals}

Pollution and the consequent contamination, eutrophication and acidification represent considerable indirect threats to biodiversity. Although problems caused directly by toxic substances have declined recently in the Nordic environment, other threats remain such as the increasing risks of oil and chemical spills.

The eutrophication of inland waters and the Baltic Sea will continue as long as nutrients are released into water bodies in sewage effluent and runoff from farmland. Many marine and inland waters are suffering from eutrophication, and sandy shores are widely becoming overgrown. Nutrient pollution also affects terrestrial habitats. Airborne nitrogen deposition increases eutrophication of traditional agricultural biotopes, speeding their overgrowth.

\section{Distinct threats faced by Greenland}

Unlike elsewhere in the Nordic Countries, the greatest threat to species and habitats in Greenland is not land use changes, but the excessive exploitation of natural resources. Hunting, fishing and other disruptive activities have together led to significant declines in the populations of many mammals, birds, fish and crustaceans. Today biologically defined quotas and close seasons are set to stop the decline.

Habitat fragmentation is not problematic in Greenland, since this vast island's lengthy icefree coastal areas are still huge in relation to its small and scattered human population. Only about 700 hectares of land in Southern Greenland is farmed. Natural habitats are not broken up by roads or other infrastructure, since traffic between settlements goes by air or sea. Oil and gas production and traffic are rising, however. Additionally, the impacts of climatic warming are already a significant threat to the biodiversity of this unique land.

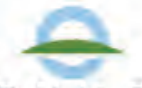

S Y K E
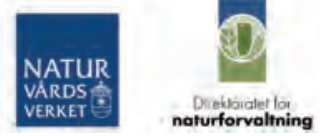

MILJØMINISTERIET By-og Landskabsstyrelsen

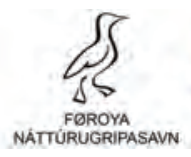

Gronlands Selvstyre

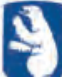

UMHVERFISSTOFNUN 


\section{Ecologically diverse sandy seashores under threat}

Sandy seashores and dunes are both popular settings for recreation and highly distinctive biotopes with their own characteristic species. But they face many threats, and the species that have adapted to thrive in their challenging natural conditions are also consequently endangered.

Shores are interfaces between dry land and water, exposed to natural forces including winds, waves, intense sunlight and the movements of ice. Sandy beaches and dunes develop on gently sloping shores, where vegetation cannot easily take root due to the shifting of the sandy substrate. Although they are naturally nutrient-poor, they receive significant inputs of nutrients when organic matter such as seaweed washes up along the shoreline. The shifting sands and the other forces operating along shorelines create distinct parallel vegetation zones extending from the water line to habitats with progressively more vegetation further inland.

\section{Specialist species}

Shore plants and animals have adapted to cope with variations in water levels, wind strength, temperatures, moisture and salinity conditions, as well as unstable substrates. Shores are species-rich environments, since their ecosystems encompass both marine and terrestrial species. Plants growing above the shoreline must be hardy and have strong roots to cope in dry, windy conditions. The most typical species include lyme grass (Leymus arenarius) and also increasingly nowadays the invasive alien Japanese rose (Rosa rugosa). Higher above the shoreline, where conditions are more stable, grasses, herbs, shrubs and trees take over as the sandy shore gradually merges into shore meadows or woodland.

Many insect species similarly adapted to these tough conditions can be found sheltering in the sand and among the shore plants. These insects, which are also threatened today, provide vital food for the many birds that breed on sandy shores or feed in such areas during migration.

One special feature of sandy shores is the banks of organic material such as brown algae washed up by the waves. These algae decay to form a nutrient-rich substrate for communities of salt-tolerant shore plants, which often form dense growths along the banks of washed up algae. Such algae bank biotopes are particularly found along Norway's seashores, where they are home to many endangered plant species.

\section{Man-made threats to Nordic sandy shores}

Along the coasts of all of the Nordic Countries sandy shores and dunes are threatened by various changes induced by human activity. Nutrient-poor sandy shores have declined in extent during recent decades. Shores and dunes are faced with eutrophication and the consequent overgrowth, climatic warming, earthworks and other construction, and increased erosion due to their popularity for recreation. Intensified shipping and the increased risk of oil spills are also growing threats.

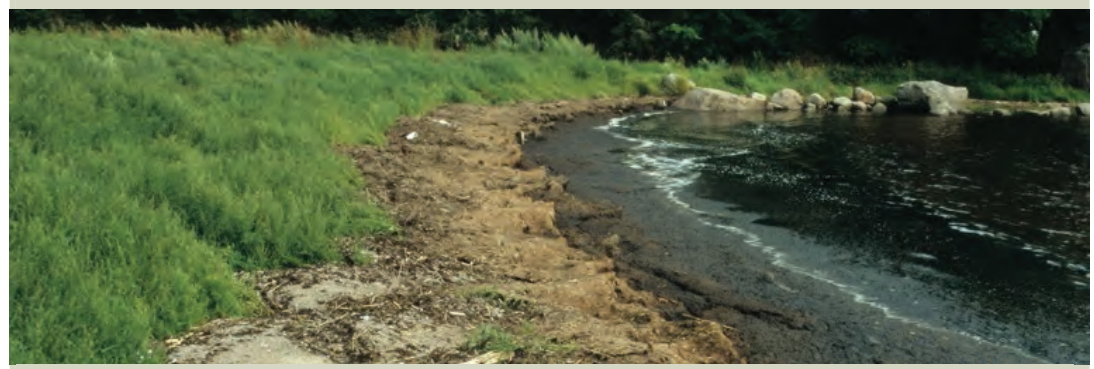

Eutrophicated and overgrown sandy beach outside Kotka in southeastern Finland. Photo: Terhi Ryttäri.
The Nordic Countries' sandy shores

The most extensive sandy beaches and dunes in the Nordic Countries lie along the North Sea coast of West Jutland in Denmark, and around Southern Sweden. The shores of the Kattegat, the Belt Sea and the Öresund Strait also have sandy shores and dunes. Finland has many sandy shores on the esker islands in the Gulf of Finland and around the Hanko Peninsula. There are also some very representative sandy beaches at the northern end of the Gulf of Bothnia. Small-scale sandy shores and dune belts are dotted around the Norwegian coast, except in the Vestland region of Western Norway. Norway's most extensive dunes lie in Finnmark. Sandy shores around the Faroe Islands, Iceland and Greenland are small in scale, largely due to their exposure to strong winds, waves and ocean currents. The sandy beaches of Greenland's east coast provide vital habitats for basking walruses.

\section{Dunes}

Dunes are low hills of wind-blown sand that accumulate where obstacles prevent the sand from being transported further by the wind. Dunes evolve through a natural succession of phases. Different species are associated with each of these development phases. Dune plants and animals must adapt to the constant shifting of the sand. Dunes are important recreational areas, but they are widely threatened by erosion and building developments.

Denmark has more dunes than any other European country except France. Dunes in all phases of development can be found along Denmark's North Sea coasts, together with their characteristic plant communities. One special feature of Denmark's coastal scenery is migrating dunes. Northern Europe's largest and most spectacular migrating dune is Råbjerg Mile, near the northern tip of Jutland. Protective measures have been initiated to enable this huge dune to slowly drift all the way from the North Sea to the Kattegat.

Smaller dunes can also be found in other parts of the Nordic Countries, including the Finnish coasts of the Gulf of Bothnia and Sweden's Haparanda archipelago. Migrating dunes are fairly common in Sweden. In Norway, dunes can particularly be found near terminal moraine formations and river deltas. The country's most extensive sandy shores and dune systems are in

Rogaland and in the north, but these features are today threatened by road construction earthworks, agricultural drainage schemes, and wave erosion. The Faroe Islands have only one dune site, known as Sandur, on the island of Sandøy. Sand extraction formerly threatened this area, but it is now protected, as it provides habitat for species found nowhere else in the Faroes.

The most serious threats to dunes are the spread of invasive Japanese roses and holiday home developments. Conflicts have arisen in Denmark where shifting sands and dunes approach holiday homes. Where holiday home-owners have tried to halt the sand by planting marram grass (Ammophila arenaria) and conifers dunes no longer go through their natural development phases, and gradually become forested. In other localities bank protection structures also inhibit the natural dynamics and development of shores and dunes. 
Eutrophication is a particularly serious threat to sandy coastal habitats around the Baltic Sea. Surplus nutrients from farmland and in sewage effluent from cities, towns and ships have boosted the growth of filamentous algae and reeds. Where such organic matter washes up along the shoreline, suitable conditions develop for plants that benefit from high nutrient levels. This leaves less room for the typical plants of nutrient-poor sandy shores, and accelerates overgrowth.

Climatic warming and the consequent reduction in ice cover also threaten typical sandy shore habitats and their species. During a normal winter, the Gulf of Finland and the Gulf of Bothnia freeze over entirely, and coastal waters also freeze in other parts of the Baltic. Ice-free winters can lead to ecological changes, since the ice normally erodes and shapes shore vegetation. Climate change will also increase precipitation, storm intensity and sea levels. These trends may prevent the natural development of dunes by raising groundwater levels, enabling the dunes to become wooded more rapidly.

In many places artificial breakwaters and embankments have been built to protect shorelines against erosion. In Denmark and Sweden, sand has been pumped back from the sea bed onto eroded beaches. Such protective measures limit the natural interaction processes between the sea and the shoreline, and inhibit the natural development of shoreline features.

The construction of holiday homes along shores also changes their natural features, and results in increased erosion. Other recreational activities can also seriously disturb natural sandy shores and dunes. Additional harmful activities include sand extraction, the artificial drainage of moist and marshy areas, and forestry on wooded dunes.

\section{Vital protection measures}

Natural sandy shore habitats need to be protected, as they are widely threatened by the spread of vegetation and consequent changes in light conditions, the availability of nutrients and the mobility of the sand. Open sandy biotopes such as beaches and dunes are gradually vanishing, together with the species that have adapted to cope with their special conditions.

Most of the Nordic Countries have designated development-free zones along all of their shores, varying in width from 100 to 300 metres. Finland, however, has no blanket ban on building along shores, but instead controls such developments through planning procedures. All of the Baltic sandy shore and dune biotopes found around Finland's coasts are under threat. The remaining natural examples are protected under national legislation, but they are still open to the public, and the consequent small-scale erosion helps to prevent their overgrowth.

Many of Denmark's sandy shores are almost intact, and they constitute the country's most unspoilt natural environments. A protected zone runs along the Danish coast extending inland from the water line for 300 metres, or 100 metres in areas with holiday homes. Inside this belt no developments are permitted that would alter the state of shore habitats. Dunes covered with vegetation are also included among the biotopes protected by Danish nature conservation legislation.

Southern Norway has hardly any pristine sandy shores, since such areas have all been greatly affected by human activity due to their favourable locations. Brackish water tidal estuaries are among Norway's most biologically productive ecosystems, and they have been widely exploited, though they remain very important for birds. In Norway building developments are prohibited in a zone extending 100 metres inland from the water line.

Swedish legislation prohibits construction and any other activities that would worsen conditions for plants and animals in a zone stretching 100 metres inland and out to sea from the water line, and this zone can be widened to 300 metres where necessary.

The future of our beloved beaches is in our own hands. We can help to preserve open sandy shores and dunes by reducing the flows of surplus nutrients into the sea, by preventing the harmful spread of the Japanese rose, by limiting construction developments, by curbing climate change, and by preventing excessive disturbance and litter.

All references are listed on the homepage of the fact sheet:

www.environment.fi/nordicnature $>$ Fact sheets $>$ Sandy seashores

\section{Japanese roses}

- unwelcome weeds on sandy shores

Japanese roses (Rosa rugosa) were originally imported from Asia as ornamental plants, but they have gradually invaded the sandy shores and dunes of the Nordic Countries, where they have benefited from eutrophication and gained ground from our rare native shore plants. These alien plants may still be legally imported and sold in the region. Once they escape into the wild they are hard to control, since their roots spread prolifically and their seeds can also be easily transported by birds or water. Attempts to weed them out are often futile, as even the tiniest root fragments left behind will send shoots up towards the surface again.

In Denmark, Norway and Finland attempts have been made to eradicate Japanese roses from certain areas using machines, followed by manual weeding, aiming to restore suitable conditions for rare native shore plants, butterflies, bugs and beetles. At Tisvildeleje on the north coast of Sjælland Japanese roses have smothered extensive areas of dune habitat. In spring 2007 , excavators dug up the plants along a $1.5-\mathrm{km}$ stretch of dunes, aiming to help restore their natural flora. The resultant plant matter was buried deep in the sand. This procedure was considered heavy-handed, but dunes can naturally adapt to changes in the layering of their sand. The project seems to have worked, as in 2009 so few new shoots appeared that they could be dug up with a spade. Over the next few years several other Japanese rose eradication methods will be tested in Denmark, including herbicides. In Norway chemical eradication techniques are already under trial.

In Finland Japanese roses are rapidly invading sandy shores and the islands of the archipelago. At the Furuvik nature reserve near Hanko, rose roots were dug up out of the sand by an excavator in 2008 , and volunteers returned to the shore in 2009 to pull out any remaining roots by hand. These measures were quite successful, but work must continue, as Japanese roses always need to be weeded out for several consecutive years.

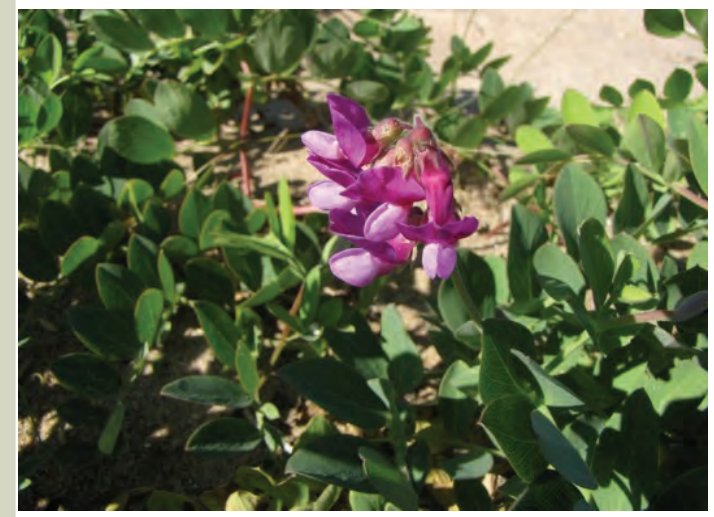

Beautiful but rare sea pea flowers (Lathyrus japonicus subsp. maritimus) occur along sandy shores throughout the Nordic Countries. Photo: Terhi Ryttäri.

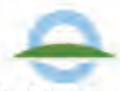

S Y K E

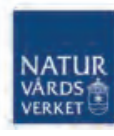

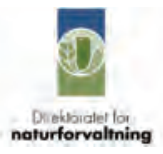

MILJØMINISTERIET By-og Landskabsstyrelsen

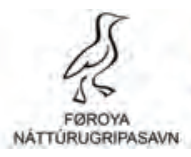

Gronland Selvstyre

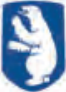

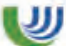

UMHVERFISSTOFNUN 


\section{Postcards highlight local responsibility for threatened species}

Picture postcards featuring threatened species including the natterjack toad (Bufo calamita), small pasque flower (Pulsatilla pratensis) and red kite (Milvus milvus) were sent in January 2007 to the heads of every single municipal authority in Denmark, with new year greetings from the current environment minister Connie Hedegaard. At the same time, every municipality was given special responsibility to protect one threatened species found locally. The idea behind the postcard campaign was to remind Denmark's new expanded municipalities of their obligation to cherish nature and ensure that threatened species are suitably protected.

\section{New year greetings}

Administrative changes implemented in Denmark at the end of 2006 shifted responsibility for the conservation of threatened species from the former provincial authorities to the municipalities. At the same time, the Ministry of the Environment resolved to conduct an innovative publicity campaign. In collaboration with the national environmental research institute, the forest and nature conservation authorities and ornithological organisations, the ministry selected one threatened plant or animal species known to live in each municipality to assign to each local authority as their specific responsibility. Postcards featuring the selected species were also sent to local media. The campaign particularly stressed Denmark's responsibility to help halt the ongoing global decline in biodiversity by 2010 . The postcards also contained references to the international Countdown 2010 initiative and its related targets.

\section{Giving conservation a face}

The postcards aimed to highlight the municipal authorities' new obligations to protect nature, and to spread information about threatened plants and animals. Assigning a single species to each municipality makes the need to conserve threatened species feel more concrete, by giving the task a face - or a flower. In addition to increasing awareness of the need to protect the chosen species, such an approach can also increase wider local interest in the conservation of other rare species found locally, and their natural habitats.
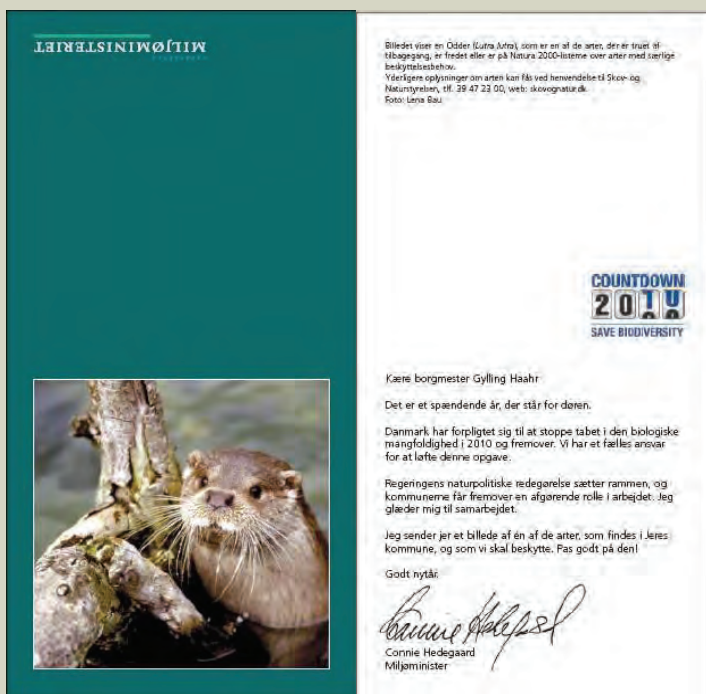

The Danish municipality of Varde received this postcard from the national environmental administration informing the local authorities about the area's otters (Lutra lutra) and calling for special collaboration on their conservation. Otter photo: Gunner Høj Christensen, AQUA.

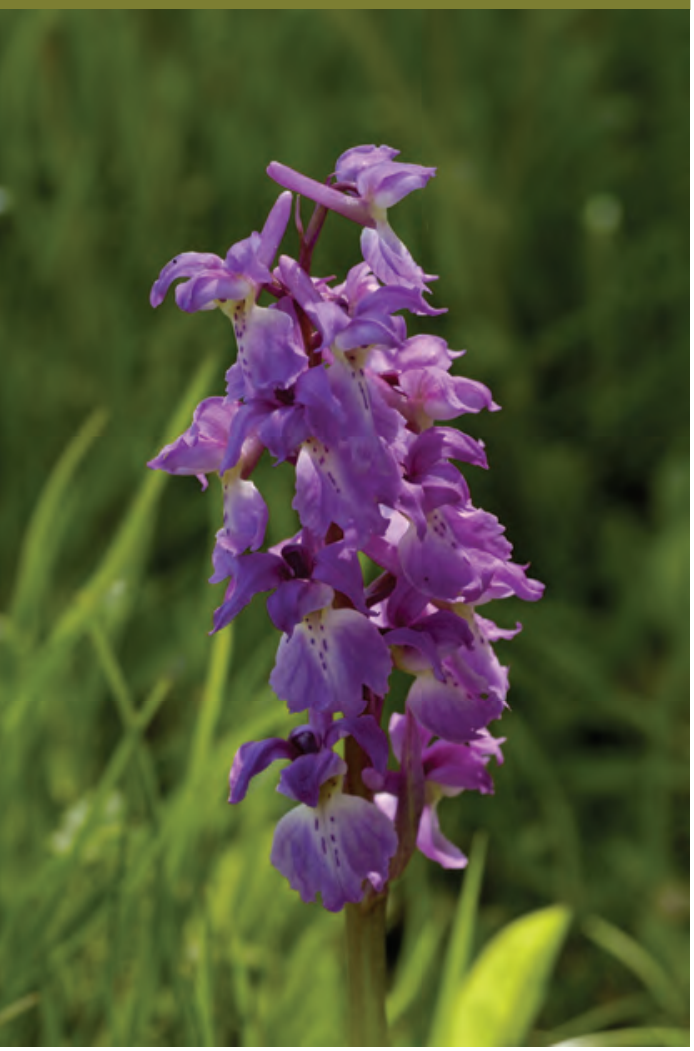

Special responsibility for protecting the beautiful but threatened early purple orchid has been assigned by the Danish environmental authorities to the municipality of Odder. Photo: Henrik Pyndt Sørensen/Biofoto.

\section{Rapid results}

The Danish municipality of Odder received a postcard from environment minister Connie Hedegaard featuring a photograph of an early purple orchid (Orchis mascula) - a species protected throughout Denmark. The minister's greetings included an appeal for the local authorities to safeguard this beautiful flower in their municipality. This work began within just two weeks, when an alert local resident warned the authorities that some of these rare orchids were at risk. A patch of some 300 orchids had spread from a marsh and an apple orchard to the banks of a ditch that the authorities had been planning to clear out. After such measures, conducted every $5-10$ years, the excavated material is usually dumped beside the ditch, where the orchids now grow. As are result of this new awareness, the authorities were able to ensure that the ditch-clearing work did not endanger the orchids. 


\section{Postcards well received around Denmark}

The postcards were warmly welcomed by heads of municipalities and local media throughout the country. The campaign gained positive media coverage in local newspapers over a period of two months. Many municipalities initiated their own nature conservation projects, including examples featured on this fact sheet.

\section{Postcard chain spreads to Norway}

Norway picked up on the successful Danish postcard campaign, launching a similar scheme in 2008. Environment minister Erik Solheim sent a total of 430 personal postcards appealing to the heads of every single municipality the length of Norway to take special care of a chosen threatened species found locally. Solheim launched the Norwegian postcard campaign by posing for the TV cameras in the municipality of Nesodde holding a great crested newt (Triturus cristatus). The campaign was well received by both municipal leaders and the media, with coverage including weekly radio slots featuring a different species every Sunday throughout 2008.

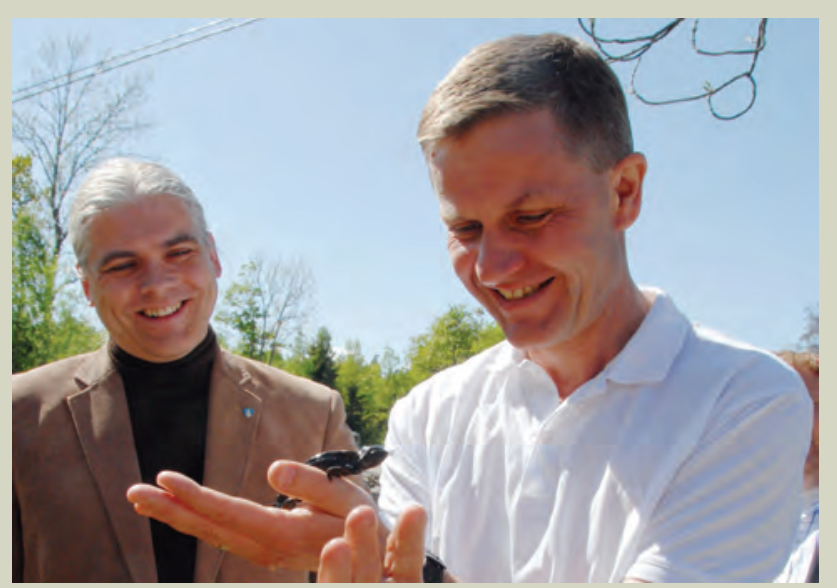

Norway's environment minister Erik Solheim goes face to face with a great crested newt. Photo: Trond Folckersahm.

\section{Similar campaigns ahead elsewhere}

Finland, the Faroe Islands and Iceland are all considering following the successful examples set in Denmark and Norway by carrying out similar postcard campaigns aiming to increase awareness at municipal level of the need to conserve biodiversity.

Denmark is also now adapting its own initiative in a new way. This latest campaign aims to highlight the need to conserve entire biotopes. The present environment minister Troels Lund Poulsen has sent new year greetings to all Danish municipalities in January 2010 using postcards featuring photographs of different types of natural habitat that are under threat.

Sources:

Agency for Spatial and Environmental Planning www.blst.dk

http://www.blst.dk/Biodiversitet/Kommune2010/truede_dyr_planter/

Danish Forest and Nature Agency www.sns.dk

Danish National Environmental Research Institute www.dmu.dk

Norwegian Directorate for Nature Management www.dirnat.no

www.dirnat.no/kommunearter

Municipality of Greve, Denmark, Michael Løgstrup

Municipality of Ishøj, Denmark, Jørgen Johansen

Municipality of Odder

Århus Stiftstidende, January 18, 2007.

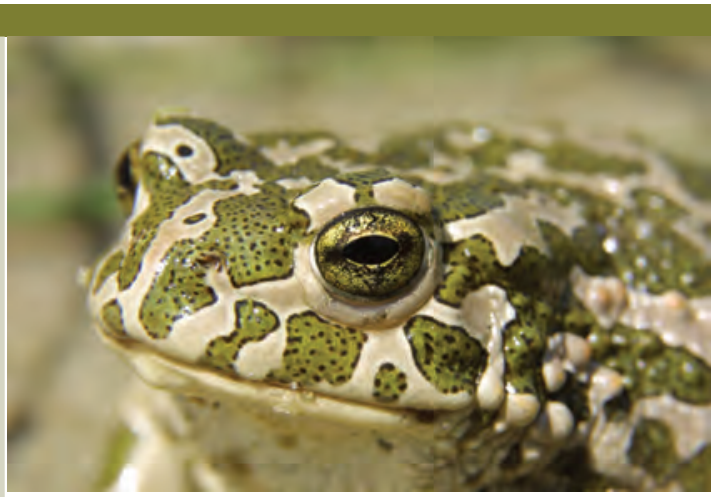

European green toad. Photo: Johnny Madsen/Biofofo.

\section{A brighter future for Denmark's green toads}

Green toads (Bufo viridis) are rare in Denmark, where they are only found in a few scattered localities on islands, including some in the municipality of Greve. The toads need to keep warm, and their toadspawn will only develop into tadpoles and tiny toads in ponds that are shallow and sunlit. The overgrowth of ponds with reeds can be a serious problem. To help their own assigned threatened species to survive, the municipal authorities of Greve have been working since 2007 with Strandparken I/S and the Danish Society for Nature Conservation, clearing reeds from seven ponds and excavating four new ponds for the toads, with positive results. Toads took over the new ponds the following summer, and in summer 2009 their croaking could be heard and their spawn spotted in eight of the area's eleven potential spawning ponds.

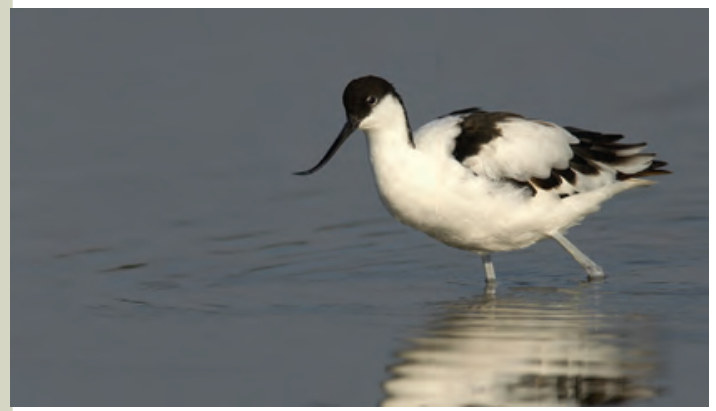

Avocets have been protected in Denmark since 1922. Photo: Lars Gejl/Biofoto.

\section{Better habitats for avocets}

The new year greetings sent to Ishøj gave the local authorities special responsibility to protect the rare avocet (Recurvirostra avosetta), which lives on shore meadows and small islands in the Strandparken area. In 2006 only three pairs nested locally, but the Ishøj authorities worked to restore suitable habitat by clearing overgrown

vegetation. Sheep and goats have also been grazed on the islands to help keep them open, in the hope that more avocets will nest. It is too early as yet to assess how these measures will affect the future prospects of these striking birds.

Finnish Environment Institute SYKE - www.environment.fi/nordicnature

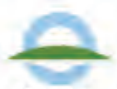

S Y K E

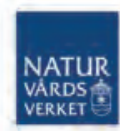

\section{MILJøMINISTERIET} Diefbialet loing
noturforvaltming
By-og Landskabsstyrelsen

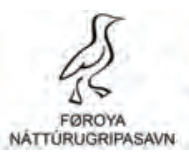

Gronlands Selvstyre

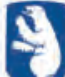




\subsection{References for the fact sheets}

1. Countdown 2010

References are listed in the fact sheet.

2. The UN Convention on Biological Diversity

References are listed in the fact sheet.

3. Ecosystem services

References are listed in the fact sheet.

4. Cod and herring stocks in the Northeast Atlantic

References are listed in the fact sheet.

5. Baltic cod and herring stocks - changing interactions between predators and prey

References are listed in the fact sheet.

6 . The triumphant return of the whitetailed eagle

Action Plan for the conservation of Whitetailed Sea Eagle (Haliaeetus albicilla). 2002. Birdlife International. Document prepared by Mr Björn Helander (Sweden) and Mr Torsten Stjernberg (Finland) on behalf of the BirdLife International Sweden.

Artdatabanken, SLU. 2006. Faktablad:

Haliaeetus albicilla havsörn.

Bakken, V., O. Runde \& E. Tjørve. 2003.

Norsk Ringmerkingsatlas. Vol. 1.

Stavanger Museum.

Birdlife International. 2004. BIRDS IN

EUROPE - Population estimates, trends and conservation status, Cambridge, U.K., Birdlife International.

Clements, J. F. 2007. The Clement's Checklist of Birds of the World. The Cornell University Press.

Ehmsen, E \& L. Pedersen. 2006.

Årsrapport for Projekt Ørn 2006, Dansk Ornitologisk Forening.

Gjershaug, J. O., P. G. Thingstad, S. Eldøy \& S. Byrkjeland. 1994. Norsk fugleatlas. Hekkefuglenes utbredelse og bestandsstatus i Norge. Norsk rnitologisk Forening.

Hailer, Frank .2006. Conservation Genetics of the White-Tailed Eagle. http://urn.kb. se/resolve?urn=urn:nbn:se:uu:diva-6911 (2007-12-07).

Helander, B., Marquiss, M. \& Bowerman, W. (eds). 2003. SEA EAGLE 2000.

Proceedings from an international

Conference at Björkö, Sweden, 13-17

September 2000. Swedish Society for the Conservation of Nature/SNF \& Åtta.45 Tryckeri AB. Stockholm.

Krone O., Stjernberg T., Kenntner N., Tataruch F., Koivusaari, J. \& Nuuja I. 2006. Mortality, helminth burden and contaminant residues in white-tailed sea eagles from Finland. Ambio 35: 98-104.

Krone, O., F. Wille, N. Kenntner, D.

Boertmann and F. Tataruch 2004.

"Mortality factors, environmental contaminants, and parasites of whitetailed sea eagles from Greenland.” Avian Diseases 48(2): 417-424.

Stjernberg, T., Koivusaari, J., Högmander, J., Ollila, T., Keränen, S., Munsterhjelm G. \& Ekblom, H. 2007. Population size and nesting success of the white-tailed sea eagle (Haliaeetus albicilla) in Finland 2005-2006. - Linnut Vuosikirja (The yearbook of the Linnut magazine) 2006:14-19. BirdLife Suomi-Finland.

Svensson, S. Svensson , M. \& Tjernberg, M. 1999. Svensk fågelatlas. Vår fågelvärld, supplement 31, Stockholm.

Svorkmo-Lundberg, T., V. Bakken, K. Mork, J. E. Røer \& S. Sæbø. 2006. Norsk VinterfuglAtlas. Norsk Ornitologisk Forening.

7. The polar bear - top arctic predator dependent on sea ice

Aars, J., Lunn, N. J. \& Derocher, A. E. (compiled and edited). 2006. Polar Bears: Proceedings of the 14th Working Meeting of the IUCN/SSC Polar Bear Specialist Group, 20-24 June 2005, Seattle, Washington, USA. IUCN, Gland, Switzerland and Cambridge, UK. Aevar Petersen 2008, Icelandic Institute of Natural History, pers. comm.

Elmer Topp-Jørgensen, 2008, Grønlands Hjemmestyre, Direktoratet for Fiskeri, Fangst og Landbrug, pers. comm.

Fernando Ugarte, 2008, Grønlands Naturinstitut, pers. comm.

Boertmann, David. 2007. Grønlands Rødliste 2007. Greenland red list. Grønlands Hjemmestyre, Direktoratet for Miljø og Natur.

Greenland Home Rule Executive order nr 21 af 22nd September 2005 on protection and hunting of polar bears. Impacts of a Warming Arctic: Artic Climate Impact Assessment ACIA. 2004. Cambridge University Press. Electronic publication at http://www.acia.uaf.edu/.

Jenssen, B. M. 2006. Endocrine-Disrupting Chemicals and Climate Change: A WorstCase Combination for Arctic Marine Mammals and Seabirds - Environmental Health Perspectives 114:76-80. 
Kit M. Kovacs, 2008, Norsk Polarinstutt, pers. comm.

Miljøovervåking - Svalbard og Jan Mayen (MOSJ) http://mosj.npolar.no/.

Peacock, E. 2008. Davis Strait Population Survey - Interim Report 2007. Department of Environment, Nunavut, Canada.

8. The unique Nordic landraces

Hallanaro, Eeva-Liisa \& Pylvänäinen

Marja. 2002. Nature in Northern Europe

- Biodiversity in a changing environment. Nord 2001:13. Nordic Council of Ministers, Copenhagen.

Heikkinen, Ilkka (ed.). 2007. Saving nature for people. National strategy and action plan for the conservation and sustainable use of biodiversity in Finland 2006-2016. Ministry of the Environment, Helsinki.

Lappalainen, Annikki \& Jääskeläinen, Liisa: Maintaining landrace plants is a cultural action (article in Finnish http://www.edu.fi/ oppimateriaalit/kasvikulttuuri/artikkelit/14 _maatiaiskasvit.htm 14.4.2008).

Lappalainen, Iiris (ed.). 1998. Suomen luonnon monimuotoisuus. [Biodiversity in Finland]. Oy Edita Ab, Helsinki. (in Finnish).

Suomen kansallinen kasvigeenivaraohjelma. 2007. Suomalaiset maatiaiskasvit -esite. Forssan kirjapaino [Finnish national action plan for plant genetic resources. 2007. Brochure on Finnish landrace plants. Only available in Finnish.]

Tiainen, J., Kuussaari, M., Laurila, I.P. Toivonen, T. (eds.). 2004. Elämää pellossa - Suomen maatalousympäristön monimuotoisuus. [Life in the fields - the biodiversity of Finland's farmland habitats.] Edita Publishing Oy, Helsinki (in Finnish).

The State of the World's Animal Genetic Resources for Food and Agriculture. 2007. Commission on Genetic Resources for Food and Agriculture. Food and Agriculture Organization of the United Nations, Rome.

9. Birds reacting to climate change Ahola, M.P., Laaksonen, T., Eeva, T. \& Lehikoinen, E. 2007. Climate change can alter competitive relationships between resident and migratory birds. Journal of Animal Ecology (2007) 76, 1,045-1,052. British Ecological Society.

Barrett, R.T. 2002. The phenology of spring bird migration to north Norway. Bird Study (2002) 49, 270-277.

Birdlife: "Climatic Atlas of European Breeding Birds” research by Professors
Brian Huntley (Durham University) and Rhys Green (BirdLife England, University of Cambridge) and $\mathrm{PhDs}$ Yvonne Collingham and Steve Willis (Durham University). Published by Lynx Publishers and BirdLifen England, BirdLife International and Durham University. European Bird Cencus Council has also collaborated.

Both, C. 2007. Comment on "Rapid Advance of Spring Arrival Dates in Long-Distance Migratory Birds”. Science Vol. 315: 598.

Both C. \& te Marvelde, L. 2007. Climate change and timing of avian breeding and migration throughout Europe. Climate Research Vol 35: 93-105.

Conservation of Nordic Nature in a Changing Climate. 2005. TemaNord 2005:572. Nordic Council of Ministers. Copenhagen.

Convention on the conservation of European wildlife and natural habitats. Standing Committee. 2nd Meeting of the Group of Experts on Biodiversity and Climate Change. Climate change and the vulnerability of Bern Convention species and habitats. Discussion paper TPVS/Inf (2008) 6. Council of Europe, Strasbourg 26 February 2008.

Framstad E. (ed.). 2006. Natur i endring. Terrestrisk naturovervåking 2005: Markvegetasjon, epifytter, smågnagere og fugl. NINA Rapport 150.

Framstad E. (ed.). 2007. Natur i endring. Terrestrisk naturovervåking 2006: Markvegetasjon, epifytter, smågnagere og fugl. NINA Rapport 262.

Intergovernmental Panel on Climate Change IPCC, Fourth Assessment Report. Climate Change 2007: Synthesis Report. Summary for Policymakers.

Jónsson, J.E., Garðarsson, A., Gill, J.A., Petersen, Æ., Gunnarsson, T.G. 2008. Does weather influence breeding numbers and spring arrival of Common Eider in NW Iceland? Natural Science Symposium 2008, March 14th and 15th in Askja (Natural Sciences Building), University of Iceland.

Jonzén N., Lindén, A., Ergon, T., Knudsen, E., Vik, J.O., Rubolini, D., Piacentini, D., Brinch, C., Spina, F., Karlsson, L., Stervander, M., Andersson, A., Waldenström, J., Lehikoinen, A., Edvardsen, E., Solvang, R., \& Stenset, N.C. 2006. Rapid Advance of Spring 
Arrival Dates in Long-Distance Migratory Birds. Science Vol. 312: 1,959-1,961.

Jonzén, N., Lindén, A., Ergon, T.,

Knudsen, E., Vik, J.O., Rubolini, D., Piacentini, D., Brinch, C., Spina, F., Karlsson, L., Stervander, M., Andersson, A., Waldenström, J., Lehikoinen, A., Edvardsen, E., Solvang, R. \& Stenseth, N.C. 2007. Response to Comment on "Rapid Advance of Spring Arrival Dates in Long-Distance Migratory Birds. Science Vol. 315: 598.

Hofgaard, A. 2004. Effekter av klimaendringer på biologiske/økologiske systemer. DNs overvåkingsdata potensial og kunnskpsressurs. NINA Oppdgragsmelding 848. 53pp.

Lehikoinen, E., Sparks, T.H., \& Zalakevicius, M. 2006. Arrival and Departure Dates. Advances in Ecological Research 35:1-31.

Ludwig, G.X. 2007. Mechanisms of Population Declines in Boreal Forest Grouse. Jyväskylä: University of Jyväskylä, 48 p. Doctoral thesis.

Ludwig, G.X., Alatalo, R.A., Helle, P, Lindén, H., Lindström, J. \& Siitari, H. 2006. Short- and long-term population dynamical consequences of asymmetric climate change in black grouse. Proc. R. Soc. B (2006) 273, 2009-2016.

Virkkala, R., Heikkinen, R. K., Leikola, N. \& Luoto, M. 2008. Projected large-scale range reductions of northern-boreal land bird species due to climate change. Biological Conservation 141 (2008) 1,343-1,353.

10. Alien Species in the Nordic Countries

Alien species in Finland. 2001. Ministry of the Environment. The Finnish Environment 466. Helsinki.

Alien species that threaten ecosystems, habitats or species. COP 6 Decision VI/23, The Hague, 7-19 April 2002.

CBD: major cross-cutting theme, Guiding Principles for the Implementation of Article 8 (h) (adopted by COP 6 Decision VI/23, The Hague, 7-19 April 2002) ("Guiding principles for the prevention, introduction and mitigation of impacts of alien species that threaten ecosystems, habitats or species").

European Strategy on Invasive Alien Species. 2003. T-PVS (2003) 7 revised. Convention on the conservation of European wildlife and natural habitats. European Strategy on Invasive Alien Species 2003. Final version. T-PVS
(2003) 7 revised. Council of Europe. Strasbourg, 5 December 2003.

Gederaas, L., Salvesen, I. \& Viken, Å. (eds.). 2007. Norsk svarteliste 2007 Økologiske risikovurderinger av fremmede arter. Artsdatabanken, Norway. (2007 Norwegian Black List Ecological Risk Analysis of Alien Species).

Global Invasive Species Programme GISP, Global Strategy on Invasive Alien Species, Toolkit of Best Prevention and Management Practises.

Hulme, Philip E. 2007. Biological Invasions in Europe: Drivers, Pressures, States, Impacts and Responses. Issues in Environmental Science and Technology, No. 25. Biodiversity Under Threat. The Royal Society of Chemistry.

Nationell strategi för främmande arter och genotyper. Delredovisning av ett regeringsuppdrag. Dnr 400-378-06 Nh. 23-06-2008. Naturvårdsverket. (Swedish national strategy for invasive alien species).

Nielsen, C., Ravn, H.P., Nentwig, W. \& Wase, M. (eds.). 2005. The Giant Hogweed Best Practice manual. Guidelines for the management and control of an invasive weed in Europe.

Weidema, I. R. (ed.). 2000. Introduced Species in the Nordic Countries. Nord 2000:13. Nordic Council of Ministers, Copenhagen.

11. Can Nordic amphibians be saved?

ArtDatabanken - The Swedish Species Information Centre: www.artdata.slu.se.

Danish Forest and Nature Agency: www.skovognatur.dk.

Finnish Museum of Natural History, University of Helsinki: www.fmnh.helsinki.fi.

Gärdenfors, U. (ed.). 2005. Rödlistade arter i Sverige 2005 - The 2005 Red List of Swedish Species. ArtDatabanken, SLU, Uppsala.

Hallanaro, Eeva-Liisa \& Pylvänäinen, Marja. 2002. Nature in Northern Europe - biodiversity in a changing world. Nord 2001:13. Nordic Council of Ministers, Copenhagen.

IUCN SSC Invasive Species Specialist Group: www.issg.org.

National Environmental Research Institute NERI: www.dmu.dk, The Danish Red Data Book.

Naturvårdsverket 2007. Åtgärdsprogram för bevarande av större vattensalamander och dess livsmiljöer (Swedish action 
plan for the great crested newt). Rapport 5636. Naturvårdsverket, Stockholm.

Norwegian Biodiversity Information Centre: www.artsdatabanken.no, Red List Database.

Norwegian Directorate for Nature Management: www.dirnat.no.

Norwegian Directorate for Nature Management. 2006. Handlingsplan for damfrosk Rana lessonae (Norwegian action plan for the pool frog Rana lessonae). DN rapport 2006-2.

Overvågning af løvfrølokaliteter mellem Vejle og Kolding 2004, Udarbejdet af Aqua Consult for Vejle Amt - Teknik og miljø (Report of monitoring of tree frog localities between Vejle and Kolding, Denmark).

Pounds, J. Alan et al. 2006. Widespread amphibian extinctions from epidemic disease driven by global warming. Nature Vol 439/12 January 2006, pp. 161-167.

Scalera, Richard, Adams, Michael J., Galvan, Stephanie K. 2008. Occurrence of Batrachochytrium dendrobatidis in Amphibian Populations in Denmark. Herpetological Review 39(2), 2008, pp. 199-200.

Vuorio Ville: Rupiliskon suojelusuunnitelma, Luonnos 2008 (Finnish action plan for the great crested newt, Draft 2008). North Karelia Regional Environment Centre.

World Association of Zoos and Aquariums (WAZA), the IUCN/SSC Conservation Breeding Specialist Group (CBSG), and the IUCN/SSC Amphibian Specialist Group (ASG): www.amphibianark.org.

12. Towards sustainable reindeer and sheep grazing in the Nordic Countries

Arnalds, O. \& B.H. Barkarson. 2003. Soil Erosion and Land Use Policy in Iceland in Relation to Sheep Grazing and Government Subsidies. Environmental Science and Policy, Vol 6, pp. 105-113.

Arnalds, O., E.F. Thorarinsdottir, S. Metusalemsson, A. Jonsson, E. Gretarsson \& A. Arnason. 2001. Soil Erosion in Iceland. Soil Conservation Service, Agricultural Research Institute, Reykjavík, Iceland.

Artsdatabanken, Norge. Fjellet - Miljøforhold og påvirkninger på rødlistearter.

Eskelinen, Anu \& Oksanen, Jari. Changes in the abundance, composition and species richness of mountain vegetation in relation to summer grazing by reindeer. 2006. In
Journal of Vegetation Science 17:245-254, 2006. IAVS: Opulus Press Uppsala.

Esselin, Anders. 2003. Storskaligt överbete i fjällen - en myt. Fjällfokus nr. 11. FjällMistra, Umeå.

Hallanaro, Eeva-Liisa \& Pylvänäinen, Marja. 2002. Nature in Northern Europe - Biodiversity in a changing environment. Nord 2001:13, Nordic Council of Ministers, Copenhagen.

Johansen, Bernt E. \& Karlsen, Stein Rune, Norut as. 2007. Finnmarksvidda kartlegging og overvåking av reinbeiter. Status 2006.

Kumpula J. et al. 2006. Porolaidunten inventoinnin kehittäminen - Keski-Lapin paliskuntien laiduninventointi vuosina 2005-2006. Kala- ja riistaraportteja nro 397. Riistan- ja kalantutkimus, Kaamanen. Linkowski, Weronika I.\& Lennartsson Tommy. 2006. Renbete och biologisk mångfald. Kunskapssammanställning. Rapportserie Nummer 18/2006.

Länsstyrelsen i Norrbottens län, Luleå. (in Swedish).

Mattila, Eero. 2006. Porojen talvilaitumien kunto poronhoitoalueen etelä- ja keskiosien merkkipiireissä 2002-2004 ja kehitys 1970-luvun puolivälistä alkaen. Metlan työraportteja 27.

Metsäntutkimuslaitos Metla.

Opi lukemaan maisemaa -

luonnonlaidunten kestävä käyttö. 2007. TemaNord 2006:587. Nordic Council of Ministers, Copenhagen.

13. Nordic inland waters successfully restored

Holopainen, I. \& Karjalainen, H. 2004. Järvet. In: M. Walls \& M. Rönkä (eds.). Veden varassa. Suomen vesiluonnon monimuotoisuus. p. 30-43. Edita Publishing Oy. Helsinki.

Ulvi, T. \& Lakso E. (eds.). 2004. Järvien kunnostus. Suomen ympäristökeskus. Edita Publishing Oy, Helsinki.

Wahlström, E. \& Hallanaro, E-L. 1996. The Future of the Finnish Environment. Edita. Finnish Environment Institute. Helsinki.

The Nordic Environment - present state, trends and threats. 1993. Nord 1993:12. Nordic Council of Ministers, Copenhagen. Puhdas Vesijärvi 2008. Päijät-Hämeen Vesijärvisäätiö.

Tuominen Lasse \& Kolunen Heikki. 1992. Vesijärvi. Luontoa - tutkimusta maisemia. Lahden kaupungin ympäristönsuojelutoimisto. 
Vuorenmaa, Jussi. 2007. Recovery responses of acidified Finnish lakes under declining acid deposition. Monographs of the Boreal Environment Research no. 30, 2007. (doctoral thesis).

The Nordic Arctic Environment Unspoilt, Exploited, Polluted? 1996. Nord 1996:26. Nordic Council of Ministers, Copenhagen.

Søndergaard, M., Jeppesen, E. \& Jensen, J. P. 1999. Danske søer og deres restaurering. TEMA-rapport fra DMU 24/1999. Miljø- og Energiministeriet, Danmarks Miljøundersøgelser.

Kalkning av sjöar och vattendrag. 2002. Handbok 2002:1. Naturvårdsverket. Startpage $>$ Arbete med naturvård $>$ Skydd och skötsel av värdefull natur $>$ Sjöar och vattendrag > Kalkning av sjöar och vattendrag.

Kalking i laksevassdrag. Effektkontroll 2007. Regionale og vassdragsvise utviklingstrekk. Notat 2008-3. Direktoratet for naturforvaltning.

14. Local contributions to halt the loss of biodiversity

References are listed in the fact sheet.

15. Traditional agricultural biotopes vanishing in the Nordic Countries

Alanen A. 1997. Maaseudun mansikkapaikat - muistojako vain? In: Turunen, S., Uotila, P., Syrjämäki, J., Koponen, T. \& Walls, M. (eds.). 1997. Suomen luonnon sata vuotta. Suomen Biologian Seura Vanamo ry. Helsinki. S. 197-208.

Edman, Staffan \& Hagman, Tore. 1988. Bondens landskap Naturskyddsföreningens årsbok 1988.

Fellestad, W., Nordenhaug, A. \& Ødegaard, F. 2008. Tidligere och nåværende jordbruksareal - miljøforhold og påvirkninger på rødlistearter. Artsdatabanken, Norge.

Nielsen, Lisbeth, Hald, Anna Bodil \& Buttenschøn, Rita Merete. 2006. Beskyttede ferske enge: Vegetation, påvirkninger, pleje, naturplanlægning. Skov- og Naturstyrelsen.

Nordic Council of Ministers. 2004. Fögur er hlíðin - Fair is the blooming meadow. A Study of Traditional Nordic and Baltic rural landscapes and biotopes and their survival in modern times. TemaNord 2004:564. Nordic Council of Ministers, Copenhagen.
Naturvårdsverket. 1997. Ängs- och hagmarker i Sverige. Ancient Meadows and Pastures in Sweden. Rapport 4819.

Pajari, Mika. 2002. Suomen uhanalaisia lajeja: Muurahaissinisiipi (Maculinea arion). Suomen ympäristö 549. Suomen ympäristökeskus, Helsinki.

Perinnemaisemien hoitotyöryhmän mietintö. 2000. Perinnebiotooppien hoito Suomessa. Suomen ympäristö SY443. Suomen ympäristökeskus, Helsinki.

Priha, Marjo (ed.). 2003. Perinnebiotooppien hoitokortit. 1 - Laidunnus/1 Bete, 2 - Niitto/2 - Slåtter, 5 - Hoidon suunnittelu/Planering av vårdbiotopernas skötsel, 6 - Tuoreet niityt ja kedot/Friska och torra ängar, 7 - Hakamaat ja metsälaitumet/Hagmarker och skogsbeten.

Pykälä, J. 2001. Perinteinen karjatalous luonnon monimuotoisuuden ylläpitäjänä. Suomen ympäristö SY495. Suomen ympäristökeskus, Helsinki.

Raunio, A., Schulman A. ja Kontula T. (eds.). 2008. Suomen luontotyyppien uhanalaisuus. Assessment of threatened habitat types in Finland - Suomen ympäristökeskus, Helsinki. Suomen ympäristö 8/2008. Parts I ja II.

Stoltze, Michael - Danske dagsommerfugle. Gyldendal 1996. Møns Klint og Klintholm. Vandreture nr. 53. Miljøministeriet. Skov- og Naturstyrelsen.

Tiainen, J., Kuussaari, M., Laurila, I. P. \& Toivonen, H. (eds.). 2004. Elämää pellossa - Suomen maatalousympäristön monimuotoisuus. Edita Publishing Oy, Helsinki. 366 s. Osa 4. Perinnebiotoopit. Osa 5.

Maatalousympäristön hoito.

16. Europe's national parks celebrate a century of conservation

Nordiska ministerrådet. 1995. Nordisk naturvård - möjligheter och problem. TemaNord 1995:501. Nordiska ministerrådet, Köpenhamn.

Nordic Council of Ministers. 1996. The Nordic Arctic Environment - Unspoilt, Exploited, Polluted? Nord 1996:26. Nordic Council of Ministers, Copenhagen.

Hallanaro, Eeva-Liisa \& Pylvänäinen, Marja. 2002. Nature in Northern Europe - biodiversity in a changing environment. Nord 2001:13. Nordic Council of Ministers, Copenhagen.

Naturvårdsverket. 2001. Nationalparkerna i Sverige. Rapport 1218.

Naturvårdsverket, Stockholm. 
Naturvårdsverket. 2008. Nationalparksplan för Sverige. Långsiktig plan. Rapport 1269. Naturvårdsverket, Stockholm.

17. Threats to biodiversity in the Nordic Countries

Boertmann, David. 2007. Grønlands Rødliste 2007. Greenland red list. Grønlands Hjemmestyre, Direktoratet for Miljø og Natur.

Gärdenfors U. (ed.). 2005. Rödlistade arter i Sverige 2005 - The 2005 Red List of Swedish Species. ArtDatabanken, SLU, Uppsala.

Hallanaro, Eeva-Liisa \& Pylvänäinen, Marja. 2002. Nature in Northern Europe - Biodiversity in a changing environment. Nord 2001:13, Nordic Council of Ministers, Copenhagen.

Kålås, J.A., Viken, Å. \& Bakken, T. (eds.). 2006. Norsk Rødliste 2006 - 2006 Norwegian Red List. Artsdatabanken, Norge.

Nordic nature - trends towards 2010 project: Fact sheets on the internet www.environment.fi/nordicnature.

Normander Bo et al. 2009. State of biodiversity in the Nordic Countries. An assessment of progress towards achieving the target of halting biodiversity loss by 2010. TemaNord 2009:509. Nordic Council of Ministers, Copenhagen 2008.

Rassi, P., Alanen, A., Kanerva, T. \& Mannerkoski, I. (eds.). 2001. Suomen lajien uhanalaisuus 2000 - The 2000 Red List of Finnish species. Ympäristöministeriö \& Suomen ympäristökeskus, Helsinki.

Raunio, A., Schulman, A. \& Kontula, T. (eds.) 2008: Suomen luontotyyppien uhanalaisuus - Osa 1. Tulokset ja arvioinnin perusteet - Assessment of threatened habitat types in Finland - Part I: Results and basis for assessment. Suomen ympäristö 8:2008.

Raunio, A., Schulman, A. \& Kontula, T. (eds.). 2008. Suomen luontotyyppien uhanalaisuus - Osa 2. Luontotyyppien kuvaukset - Assessment of threatened habitat types in Finland - Part II: Habitat type descriptions. - Suomen ympäristö 8:2008.

Stoltze, M. \& Pihl, S. (eds.). 1998. Rødliste 1997 over planter og dyr i Danmark. The Danish Red List 1997. Miljø- og
Energiministeriet, Danmarks Miljøundersøgelser og Skov- og Naturstyrelsen. 18. Ecologically diverse sandy seashores under threat

Agerlund, S. \& Vestergaard, P. 2007. Forsøg med opgravning af rynket rose i klitterræn. In: Weidema, I. et al. (eds.). Rynket rose (Rosa rugosa) i Danmark. Rapport fra workshop på Biologisk Institut, Københavns Universitet, 5-6 september 2006. Biologisk Institut, Københavns Universitet, Skov og Landskab, Københavns Universitet, Skov- og Naturstyrelsen, pp. 72-74. Dalsgarð J., Fosaa A.M. och Gaard E. (eds.). Føroya Náttúra, 2006. Føroya Skúlabókagrunnur, Tórshavn.

Direktoratet for naturforvaltning. 2007. Kartlegging av naturtyper - verdisetting av biologisk mangfold. Håndbok 13, 2. edition 2006.

Hallanaro, Eeva-Liisa \& Pylvänäinen, Marja. 2002. Nature in Northern Europe - Biodiversity in a changing environment. Nord 2001:13. Nordic Council of Ministers, Copenhagen.

Kekäläinen, H., Keynäs, K., Koskela, K., von Numers, M., Rinkineva-Kantola L., Ryttäri, T. \& Syrjänen, K. 2008. Itämeren rantaluontotyypit. In: Raunio, A., Schulman, A. \& Kontula, T. (eds.). 2008. Suomen luontotyyppien uhanalaisuus - Osa 2. Luontotyyppien kuvaukset. - Suomen ympäristö 8:2008. P. 35-88.

Kustbiotoper i Norden. 2001. Hotade och representativa biotoper. Nord 2001:536. Nordiska Minister-rådet, Köpenhamn.

Miljø- og Energiministeriet, Skov- og Naturstyrelsen. 1999. Skov- og Naturstyrelsens naturplejestrategi.

Miljøministeriet, Skov- og Naturstyrelsen, Danmarks Naturfredningsforening, Friluftsrådet. 2004. Beskyt den vilde flora ved kysterne. Rynket Rose og andre indførte planter udrydder oprindelige og værdifulde plantesamfund.

Miljøministeriet, Skov- og Naturstyrelsen. 2009. Skov og natur i tal 2009.

Olsen, Søren. 2000. Danmarks natur. Guide til 166 naturseværdigheder. Politikens forlag A/S.

19. Postcards highlight local responsibility for threatened species References are listed in the fact sheet. 



\section{Appendices I}

Table 1: Nordic amphibian species. Occurrence and threat status and names in Nordic languages and English. Appendix to the fact sheet 11. Can Nordic amphibians be saved?

\begin{tabular}{|c|c|c|c|c|c|c|c|c|c|}
\hline & Finland & & Sweden & & Norway & & Denmark & & \\
\hline Bufo bufo & rupikonna & LC & Padda & LC & padde & LC & skrubtudse & LC & $\begin{array}{l}\text { common toad/ } \\
\text { european toad }\end{array}$ \\
\hline $\begin{array}{l}\text { Bufo } \\
\text { calamita }\end{array}$ & haisukonna & - & stinkpadda & EN & strandpadde & - & strandtudse & LC & natterjack toad \\
\hline $\begin{array}{l}\text { Bufo } \\
\text { viridis }\end{array}$ & viherkonna & - & $\begin{array}{l}\text { grönfläckig } \\
\text { padda }\end{array}$ & $\mathrm{CR}$ & $\begin{array}{l}\text { grønnflekket } \\
\text { padde }\end{array}$ & - & $\begin{array}{l}\text { grønbroget } \\
\text { tudse }\end{array}$ & LC & $\begin{array}{l}\text { European } \\
\text { green toad }\end{array}$ \\
\hline $\begin{array}{l}\text { Bombina } \\
\text { bombina }\end{array}$ & $\begin{array}{l}\text { Kellosam- } \\
\text { makko }\end{array}$ & - & klockgroda & NT & klokkefrosk & - & klokkefrø & NT & $\begin{array}{l}\text { european fire- } \\
\text { bellied toad }\end{array}$ \\
\hline $\begin{array}{l}\text { Hyla } \\
\text { arborea }\end{array}$ & $\begin{array}{l}\text { euroopanlehti } \\
\text { sammakko }\end{array}$ & - & Lövgroda & $\mathrm{LC}$ & løvfrosk & - & løvfrø & $\mathrm{LC}$ & $\begin{array}{l}\text { european tree } \\
\text { frog }\end{array}$ \\
\hline $\begin{array}{l}\text { Pelobates } \\
\text { fuscus }\end{array}$ & $\begin{array}{l}\text { Kaivajasam- } \\
\text { makko }\end{array}$ & - & Lökgroda & NT & løkfrosk & - & løgfrø & $\mathrm{DD}$ & $\begin{array}{l}\text { Spadefoot } \\
\text { toad/common } \\
\text { spadefoot }\end{array}$ \\
\hline $\begin{array}{l}\text { Rana } \\
\text { temporaria }\end{array}$ & sammakko & LC & vanlig groda & LC & buttsnutefrosk & LC & $\begin{array}{l}\text { butsnudet } \\
\text { frø }\end{array}$ & LC & $\begin{array}{l}\text { common } \\
\text { frog/european } \\
\text { common } \\
\text { frog/european } \\
\text { common brown } \\
\text { frog }\end{array}$ \\
\hline $\begin{array}{l}\text { Rana } \\
\text { arvalis }\end{array}$ & viitasammakko & LC & Åkergroda & LC & spissnutefrosk & NT & $\begin{array}{l}\text { spidssnudet } \\
\text { frø }\end{array}$ & LC & moor frog \\
\hline $\begin{array}{l}\text { Rana } \\
\text { dalmatina }\end{array}$ & $\begin{array}{l}\text { Hyppysam- } \\
\text { makko }\end{array}$ & - & långbensgroda & VU & springfrosk & - & springfrø & LC & agile frog \\
\hline $\begin{array}{l}\text { Rana } \\
\text { lessonae }\end{array}$ & $\begin{array}{l}\text { lessonansam } \\
\text { makko }\end{array}$ & - & Gölgroda & VU & damfrosk & $\mathrm{CR}$ & & - & pool frog \\
\hline $\begin{array}{l}\text { Rana } \\
\text { ridibunda }\end{array}$ & $\begin{array}{l}\text { Mölysam- } \\
\text { makko }\end{array}$ & $\begin{array}{l}\text { Occa- } \\
\text { sional }\end{array}$ & Sjögroda & - & latterfrosk & - & latterfrø & $\mathrm{DD}$ & marsh frog \\
\hline $\begin{array}{l}\text { Rana } \\
\text { esculenta }\end{array}$ & $\begin{array}{l}\text { Vihersam- } \\
\text { makko }\end{array}$ & - & ätlig groda & LC & hybridfrosk & - & grøn frø & LC & $\begin{array}{l}\text { common water } \\
\text { frog/green } \\
\text { frog/edible frog }\end{array}$ \\
\hline $\begin{array}{l}\text { Triturus } \\
\text { cristatus }\end{array}$ & rupilisko & Vu & $\begin{array}{l}\text { större vatten- } \\
\text { salamander }\end{array}$ & LC & $\begin{array}{l}\text { stor } \\
\text { salamander }\end{array}$ & VU & $\begin{array}{l}\text { stor vand- } \\
\text { salamander }\end{array}$ & LC & $\begin{array}{l}\text { great crested } \\
\text { newt }\end{array}$ \\
\hline $\begin{array}{l}\text { Triturus } \\
\text { vulgaris }\end{array}$ & vesilisko & LC & $\begin{array}{l}\text { mindre vatten- } \\
\text { salamander }\end{array}$ & LC & $\begin{array}{l}\text { liten } \\
\text { salamander }\end{array}$ & NT & $\begin{array}{l}\text { lille vand- } \\
\text { salamander }\end{array}$ & LC & smooth newt \\
\hline $\begin{array}{l}\text { Triturus } \\
\text { alpestris }\end{array}$ & alppivesilisko & - & $\begin{array}{l}\text { bergvattensala } \\
\text { mander }\end{array}$ & - & $\begin{array}{l}\text { Bergsala- } \\
\text { mander }\end{array}$ & - & $\begin{array}{l}\text { bjergsalam } \\
\text { ander }\end{array}$ & LC & alpine newt \\
\hline
\end{tabular}

$\mathrm{CR}=$ critically endangered, $\mathrm{EN}=$ endangered, $\mathrm{VU}=$ vulnerable, $\mathrm{NT}=$ near threatened, $\mathrm{LC}=$ least concern, $\mathrm{DD}=$ data deficient The classes $\mathrm{CR}, \mathrm{EN}$ and $\mathrm{VU}$ are concidered endangered

All amphibian species are protected in Finland, Sweden, Norway and Denmark

Sources:

Finland: Rassi,P., Alanen, A., Kanerva, T. \& Mannerkoski, I. (eds.). 2001. Suomen lajien uhanalaisuus 2000 - The 2000

Red List of Finnish species. Ministry of the Environment \& Finnish Environment Institute. Helsinki.

Sweden: Gärdenfors, U. (ed.). 2005. Rödlistade arter i Sverige - The 2005 Redlist of Swedish Species. Swedish Species Information Centre. SLU. Uppsala.

Norway: Kålås, J.A., Viken, Å. \& Bakken, T. (eds.). 2006. Norsk Rødliste 2006 - 2006 Norwegian Red List. The Norwegian Biodiversity Information Centre.

Denmark: Den danske rødliste - The Danish Red List. National Environmental Research Institute 2004, Aarhus University. [http://redlist.dmu.dk]

Table compiled by the project Nordic nature - trends towards 2010, for the fact sheet "Can Nordic amphibians be saved?" [www.environment.fi/nordicnature.fi] > Fact sheets > Amphibians in the Nordic Countries. Published 11 Dec 2008. 
Table 2: Number of red listed species in traditional agricultural environments in the Nordic Countries. Appendix to the fact sheet 15. Traditional agricultural biotopes vanishing in the Nordic Countries

\begin{tabular}{|c|c|c|c|c|c|c|c|}
\hline & & \multicolumn{3}{|c|}{ Finland } & \multicolumn{3}{|c|}{ Sweden } \\
\hline & & trad.agric.env. & total & $\%$ & trad.agric.env. & total & $\%$ \\
\hline Algae & Algae $^{1}$ & 0 & 6 & 0 & 6 & 34 & 18 \\
\hline Mosses & $\begin{array}{l}\text { Bryophyta, } \\
\text { Marchantiophyta, } \\
\text { Anthocerophyta }\end{array}$ & 0 & 136 & 0 & 60 & 220 & 27 \\
\hline Vascular plants & Tracheophyta & 50 & 180 & 28 & 329 & 485 & 68 \\
\hline Fungi & Fungi $^{2}$ & 80 & 649 & 12 & 198 & 632 & 31 \\
\hline Lichens & Lichenes & 10 & 99 & 10 & 120 & 254 & 47 \\
\hline $\begin{array}{l}\text { Amphibians and } \\
\text { reptiles }\end{array}$ & Amphibia, Reptilia & 1 & 3 & 33 & 6 & 9 & 67 \\
\hline Birds & Aves & 4 & 32 & 13 & 35 & 91 & 38 \\
\hline Mammals & Mammalia & 1 & 7 & 14 & 7 & 19 & 37 \\
\hline Annelids & Annelida $^{3}$ & 320 & 759 & 42 & 2 & 2 & 100 \\
\hline Molluscs & Mollusca & 0 & 11 & 0 & 5 & 130 & 4 \\
\hline Arachnids & Arachnida $^{4}$ & 1 & 12 & 8 & 22 & 71 & 31 \\
\hline Crustaceans & Crustacea & 0 & 0 & 0 & 5 & 46 & 11 \\
\hline $\begin{array}{l}\text { Mayflies, dragonflies, } \\
\text { stoneflies, net-winged } \\
\text { insects, caddisflies }\end{array}$ & $\begin{array}{l}\text { Ephemeroptera, Odo- } \\
\text { nata, Plecoptera, Neu- } \\
\text { roptera, Trichoptera }^{5}\end{array}$ & 0 & 14 & 0 & 3 & 50 & 6 \\
\hline Myriapods & Myriapoda $^{6}$ & 1 & 4 & 25 & 2 & 14 & 14 \\
\hline Orthopterans & Orthoptera $^{7}$ & 2 & 4 & 50 & 4 & 5 & 80 \\
\hline Hempiterans & Hemiptera $^{8}$ & 25 & 44 & 57 & 30 & 52 & 58 \\
\hline Butterflies and moths & Lepidoptera & 137 & 241 & 57 & 250 & 379 & 66 \\
\hline Dipterans & Diptera & 2 & 12 & 17 & 59 & 165 & 36 \\
\hline Hymenopterans & Hymenoptera & 48 & 68 & 71 & 135 & 184 & 73 \\
\hline Beetles & Coleoptera & 104 & 347 & 30 & 505 & 848 & 60 \\
\hline
\end{tabular}

trad.agric.env. - number of red listed species per species group that mainly occur in traditional agricultural environments SE: number of red listed species that occur in traditional agricultural environments

total - total number of red listed species per species group

$\%$ - percentage of species that mainly occur in traditional agricultural environments of all red listed species - data not available

FI: dry meadows, mesic meadows, grazed woodlands and pollard meadows, moist meadows, ditches and ditch verges, arable land, parks, yards and gardens, ruderal areas, buildings.

SE: arable land, grazed woodlands, park lanes in agricultural areas, palace parks, yards, alvars, heather heaths, marl pits, ponds and small grazed mires in the agricultural environment.

NO: agricultural environment and associated infrastructures such as roads and buildings etc

DK: meadows and commons 


\begin{tabular}{|c|c|c|c|c|c|c|c|}
\hline & & \multicolumn{3}{|c|}{ Norway } & \multicolumn{3}{|c|}{ Denmark } \\
\hline & & trad.agric.env. & total & $\%$ & trad.agric.env. & total & $\%$ \\
\hline Algae & Algae $^{1}$ & 0 & 62 & 0 & - & - & - \\
\hline Mosses & $\begin{array}{l}\text { Bryophyta, } \\
\text { Marchantiophyta, } \\
\text { Anthocerophyta }\end{array}$ & 60 & 267 & 22 & - & - & - \\
\hline Vascular plants & Tracheophyta & 185 & 569 & 33 & 37 & 102 & 36 \\
\hline Fungi & Fungi $^{2}$ & 217 & 880 & 25 & 81 & 405 & 20 \\
\hline Lichens & Lichenes & 83 & 269 & 31 & 9 & 316 & 3 \\
\hline $\begin{array}{l}\text { Amphibians and } \\
\text { reptiles }\end{array}$ & Amphibia, Reptilia & 4 & 17 & 24 & 2 & 5 & 40 \\
\hline Birds & Aves & 25 & 138 & 18 & 3 & 29 & 10 \\
\hline Mammals & Mammalia & 10 & 47 & 21 & 0 & 11 & 0 \\
\hline Annelids & Annelida $^{3}$ & 0 & 0 & 0 & - & - & - \\
\hline Molluscs & Mollusca & 0 & 48 & 0 & - & - & - \\
\hline Arachnids & Arachnida $^{4}$ & 44 & 112 & 39 & - & - & - \\
\hline Crustaceans & Crustacea & 0 & 43 & 0 & - & - & - \\
\hline $\begin{array}{l}\text { Mayflies, dragonflies, } \\
\text { stoneflies, net-winged } \\
\text { insects, caddisflies }\end{array}$ & $\begin{array}{l}\text { Ephemeroptera, Odo- } \\
\text { nata, Plecoptera, Neu- } \\
\text { roptera, Trichoptera }^{5}\end{array}$ & 1 & 100 & 1 & 0 & 43 & 0 \\
\hline Myriapods & Myriapoda $^{6}$ & 4 & 20 & 20 & - & - & - \\
\hline Orthopterans & Orthoptera $^{7}$ & 3 & 6 & 50 & - & - & - \\
\hline Hempiterans & Hemiptera $^{8}$ & 43 & 112 & 38 & 5 & 9 & 56 \\
\hline Butterflies and moths & Lepidoptera & 266 & 567 & 47 & 39 & 87 & 45 \\
\hline Dipterans & Diptera & 49 & 289 & 17 & 12 & 35 & 34 \\
\hline Hymenopterans & Hymenoptera & 37 & 147 & 25 & - & - & - \\
\hline Beetles & Coleoptera & 298 & 995 & 30 & 138 & 561 & 25 \\
\hline
\end{tabular}

${ }^{1}$ Fl: makroalgae, SE: Nostocophycaeae, Phaeophycaeae, Rhodophyta, Charophycaeae, NO: Cyanophyta, Rhodophyta, Phaeophycaeae, Ulvophycaeae, Charophycaeae ${ }^{2}$ SE: Makrofungi ${ }^{3}$ SE: Hirudinea, Tricladida ${ }^{4} \mathrm{NO}$ : Araneae ${ }^{5} \mathrm{FI}:+$ Mecoptera, NO: + Mecoptera, Raphidioptera, Megaloptera ${ }^{6} \mathrm{Fl}$ : Chilopoda, Diplopoda ${ }^{7} \mathrm{NO}$ : + Blattodea, Dermaptera ${ }^{8}$ DK: Pentatomoidea, Coreoidea

Sources:

FI: Rassi, P., Alanen, A., Kanerva, T. \& Mannerkoski, I. (ed.) 2001: Suomen lajien uhanalaisuus 2000 (The 2000 Red List of Finnish Species). - Ministry of the environment \& Finnish environment institute, Helsinki

SE: Artdatabanken, [www.artdata.slu.se/rodlista/index.cfm], 25.3.2009.

NO: Kålås, J.A., Viken, Å. og Bakken, T. (ed.) 2006: Norsk rødliste 2006 (2006 Norwegian Red List). Artsdatabanken, Norway.

DK: Stoltze, M. og Pihl, S. (ed.) 1998: Rødliste 1997 over planter og dyr i Danmark (Danish Red List 1997). Miljø- og Energiministeriet, Danmarks Miljøundersögelser and Skov- og Naturstyrelsen

The table is compiled in the project Nordic nature - trends towards 2010 for the fact sheet Traditional agricultural biotopes vanishing in the Nordic Countries.

[www.environment.fi/nordicnature] > Fact sheets > Traditional agricultural biotopes vanishing. Published 15 june 2009.

Table 3: National parks in the Nordic Countries. Appendix to the fact sheet 16. Europe's national parks celebrate a century of conservation

\begin{tabular}{lr}
\hline & Established national parks \\
\hline Finland & 35 \\
\hline Sweden & 29 \\
Norway & 31 \\
Svalbard & 7 \\
Denmark & 2 \\
Greenland & - (first one is planned) \\
Faroe Islands & 3 \\
Iceland & \\
\hline
\end{tabular}

\section{Sources:}

World Database on Protected Areas [www.wdpa.org]

Metsähallitus, Finland, [www.outdoors.fi]

Swedish Environmental Protection Agency, [www.naturvardsverket.se/nationalparker]

Directorate for Nature Management, Norway, [www.dirnat.no/nasjonalparker]

The Danish Forest and Nature Agency, nationalparker.skovognatur.dk. 



\section{Appendices II}

Table 4: Total species numbers and numbers of threatened species in the Nordic Countries according to species group and country

\begin{tabular}{|c|c|c|c|c|c|c|c|}
\hline & Finland & Sweden & Norway & Denmark & Iceland & $\begin{array}{r}\text { Faroe } \\
\text { Islands }\end{array}$ & Greenland \\
\hline \multicolumn{8}{|l|}{ Mammals } \\
\hline species $^{1}$ & 65 & 62 & 89 & 50 & 26 & $?$ & 30 \\
\hline assessed $^{2}$ & 58 & 62 & 75 & $?$ & $?$ & $?$ & 37 \\
\hline threatened $^{3}$ & 7 & 11 & 12 & $?$ & $?$ & $?$ & 10 \\
\hline \multicolumn{8}{|l|}{ Birds $^{4}$} \\
\hline species & 240 & 251 & 248 & 200 & 76 & 54 & 58 \\
\hline assessed & 229 & 251 & 230 & $?$ & 76 & 54 & 65 \\
\hline threatened & 32 & 43 & 37 & $?$ & 32 & 29 & 9 \\
\hline \multicolumn{8}{|c|}{$\begin{array}{l}\text { Amphibians and } \\
\text { reptiles }\end{array}$} \\
\hline species & 10 & 19 & 12 & 21 & 0 & 0 & 0 \\
\hline assessed & 10 & 19 & 11 & $?$ & - & - & - \\
\hline threatened & 3 & 6 & 2 & $?$ & - & - & - \\
\hline \multicolumn{8}{|l|}{ Fish } \\
\hline species & 68 & 141 & 289 & 258 & 300 & 247 & c. 150 \\
\hline assessed & 68 & 141 & 208 & $?$ & $?$ & 0 & 3 \\
\hline threatened & 8 & 18 & 10 & $?$ & $?$ & - & 1 \\
\hline \multicolumn{8}{|l|}{ Insects } \\
\hline species & 19,846 & 23,679 & 20,945 & 18,000 & 1,268 & 1,016 & 375 \\
\hline assessed & 9,786 & 10,003 & 8,702 & $?$ & $?$ & 0 & 5 \\
\hline threatened & 731 & 689 & 912 & $?$ & $?$ & - & 0 \\
\hline \multicolumn{8}{|l|}{ Arachnids } \\
\hline species & 2,500 & 1,790 & 1,637 & $?$ & 96 & 212 & 192 \\
\hline assessed & 39 & 740 & 584 & $?$ & $?$ & 0 & 0 \\
\hline threatened & 12 & 16 & 68 & $?$ & $?$ & - & - \\
\hline \multicolumn{8}{|l|}{ Molluscs } \\
\hline species & 161 & 608 & 874 & 326 & c. 450 & $>380$ & 283 \\
\hline assessed & 153 & 490 & 622 & $?$ & $?$ & 0 & 0 \\
\hline threatened & 11 & 41 & 15 & $?$ & $?$ & - & - \\
\hline \multicolumn{8}{|c|}{ Other invertebrates } \\
\hline species & 983 & 1,731 & $?$ & $?$ & 1,500 & $?$ & c. 1,784 \\
\hline assessed & 459 & 301 & $?$ & $?$ & $?$ & $?$ & 0 \\
\hline threatened & 9 & 30 & $?$ & $?$ & $?$ & $?$ & - \\
\hline \multicolumn{8}{|c|}{ Vascular plants ${ }^{5}$} \\
\hline species & $\begin{array}{r}\text { c. } 2,000 / \\
>1,200\end{array}$ & 1,638 & 2,834 & $1,050 / 430$ & 485 & 401 & 515 \\
\hline assessed & 1,240 & 1,628 & 1,360 & $?$ & 485 & 0 & 5 \\
\hline threatened & 180 & 261 & 217 & $?$ & 52 & - & 1 \\
\hline & & & & & & \multicolumn{2}{|c|}{ To be continued } \\
\hline
\end{tabular}




\begin{tabular}{|c|c|c|c|c|c|c|c|}
\hline & Finland & Sweden & Norway & Denmark & Iceland & $\begin{array}{r}\text { Faroe } \\
\text { Islands }\end{array}$ & Greenland \\
\hline \multicolumn{8}{|l|}{ Mosses } \\
\hline species & 883 & 1,085 & 1,968 & 548 & 606 & 415 & c. 612 \\
\hline assessed & 856 & 989 & 1,062 & $?$ & 450 & 0 & 0 \\
\hline threatened & 136 & 92 & 142 & $?$ & 74 & - & - \\
\hline \multicolumn{8}{|l|}{ Lichens } \\
\hline species & 1,452 & 2,408 & 1,976 & 950 & 830 & 470 & c. 950 \\
\hline assessed & 1,450 & 1,021 & 1,207 & $?$ & 270 & 0 & 0 \\
\hline threatened & 99 & 136 & 168 & $?$ & 67 & - & - \\
\hline \multicolumn{8}{|l|}{ Algae } \\
\hline species & $<6,000$ & 598 & 755 & $>516$ & 500 & 213 & 2,115 \\
\hline assessed & 111 & 219 & 301 & $?$ & 238 & 0 & 0 \\
\hline threatened & 6 & 20 & 18 & $?$ & 42 & - & - \\
\hline \multicolumn{8}{|l|}{ Fungi } \\
\hline species & 4,798 & 4,800 & 10,000 & 3,000 & 1,880 & 626 & c. 1,600 \\
\hline assessed & 3,798 & 4,000 & 2,402 & $?$ & $?$ & 0 & 0 \\
\hline threatened & 265 & 301 & 324 & $?$ & $?$ & - & - \\
\hline
\end{tabular}

${ }^{1}$ Estimated number of species per group in each country.

${ }^{2}$ Species whose status has been assessed.

${ }^{3}$ Assessed species classified as threatened (Critically endangered CR, Endangered EN, Vulnerable VU).

${ }^{4}$ Nesting birds.

${ }^{5}$ Vascular plants apomictic plants.

Remarks:

- Finland: algae - only macroalgae have been assessed, but the total species number also includes microalgae.

- Sweden: vascular plants - no subspecies, varieties etc.; other invertebrates - myriapods, crustaceans, echinoderms,

brachiopods, leeches, planarians, anthozoans. An additional c. 9,000 multicellular species in Sweden have not been assessed.

- Norway: algae only macroalgae are incuded; mammals - includes species in Svalbard; vascular plants - subspecies not included.

- Iceland: Arachnids - Acari excluded, fish - both marine and fresh water fish, mammals - both terrestrial and marine.

- Greenland: mammals - subspecies also evaluated; birds species that regularly summer or winter in Greenland have also been assessed, even if they do not nest.

IUCN red list categories

$\mathrm{CR}=$ Critically Endangered, $\mathrm{EN}=$ Endangered, $\mathrm{VU}=$ Vulnerable, $\mathrm{NT}=$ Near Threatened, $\mathrm{LC}=$ Least Concern, $\mathrm{DD}=$ Data Deficient, NE $=$ Not Evaluated, $\mathrm{RE}=$ Regionally Extinct, $\mathrm{EW}=$ Extinct in the Wild 


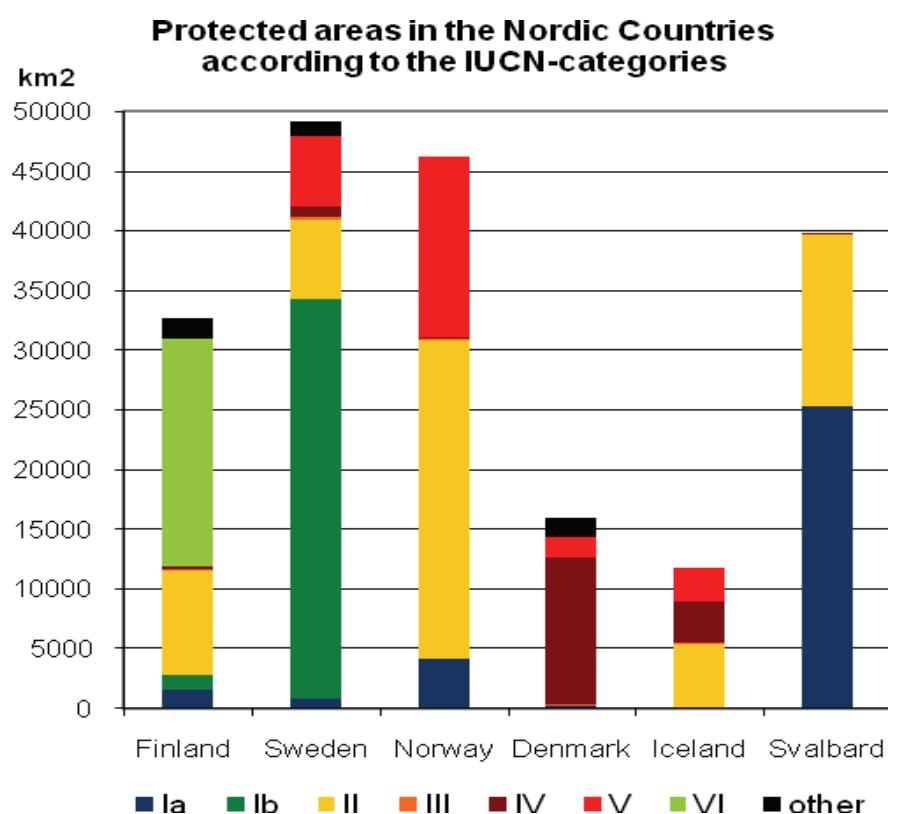

Figure 1: Protected areas in the Nordic Countries

Notes:

In Norway (incl. Svalbard) the classes la and Ib are not separated. In the graph la represents Norway's combined class I. In Finland only a few protected areas are classified according to the IUCN categories, and the unclassified areas are here included in "other". Greenland has about 982,550 sq km of protected areas, mostly of class II, which are not included in the graph.

Sources:

The Finnish register of protected areas 2006, UN List of Protected areas 2003, Directorate for nature Management, Norway 2007, Environment and Food Agency of Iceland 2007

IUCN categories for protected areas:

la: Strict Nature Reserve: protected area managed mainly for science.

Ib: Wilderness Area: protected area managed mainly for wilderness protection.

II: National Park: protected area managed mainly for ecosystem protection and recreation.

III: Natural Monument: protected area managed mainly for conservation of specific natural features.

IV: Habitat/Species Management Area: protected area managed mainly for conservation through management intervention.

$\mathrm{V}$ : Protected Landscape/Seascape: protected area managed mainly for landscape/seascape conservation and recreation. VI: Managed Resource Protected Area: protected area managed mainly for the sustainable use of natural ecosystems.

More precise definitions of the categories:

These categories are defined in detail in the Guidelines for Protected Areas Management Categories published by IUCN in 1994. [http://www.unep-wcmc.org/protected_areas/categories/index.html] 


\subsection{References for the table}

Finland

Rassi, P., Alanen, A., Kanerva, T. \& Mannerkoski, I. (eds.). 2001. Suomen lajien uhanalaisuus 2000 - The 2000 Red List of Finnish species. Ympäristöministeriö \& Suomen ympäristökeskus, Helsinki.

Sweden

Gärdenfors, U. (ed.). 2005. Rödlistade arter i Sverige 2005 - The 2005

Redlist of Swedish Species.

Artdatabanken, Uppsala.

Norway

Kålås, J.A., Viken, Å. \& Bakken, T. (eds.). 2006. Norsk Rødliste 2006 2006 Norwegian Red List,

Artsdatabanken, Norge.

Bakken, T. et al. 2005. Utredning for Artsdatabanken, Artsdatabanken, Norge.

Viken, Å. \& Kålås, J.A. 2007: Rødlista og insektene, Insekt-Nytt 32 (1/2) 2007.

Denmark

Stoltze, M. \& Pihl, S. (eds.). 1998. Rødliste 1997 over planter og dyr i Danmark. Miljø- og

Energiministeriet, Danmarks miljøundersøgelser \& Skov- og Naturstyrelsen.

Prip, C., Wind, P. \& Jørgensen, H. 1995. Biologisk mangfoldighet $\mathrm{i}$ Danmark - Status og strategi, Miljøog Energiministeriet.
Iceland

Hersteinsson, P. \& Sigbjarnarson, G. (eds.). 1993. Villt íslensk spendýr. Hið íslenska náttúrufræðifélag, Landvern.

Náttúrufræðistofnun Íslands. 2000: Válisti 2: Fuglar. Reykjavík.

Agnarson, I. 1996. íslenskur köngulær. Fjölrit Náttúrufræðistofnunar 31.

Náttúrufræðistofnun Íslands 1996. Válisti 1: Plöntur. Reykjavík.

Jón Baldur Sigurðsson. Náttúrustofa Reykjaness, Island, pers. comm.

Guðmundur A. Guðmundsson, Náttúrufræðistofnun Íslands, pers. comm.

Karl Gunnarson, Guðriður Gyða Eyjólfsdóttir \& Gunnar Jónsson, Hafsrannsóknastofnunin, Island, pers. comm.

Erling Ólafsson, Náttúrufræðistofnun Íslands, pers. comm.

Faroe Islands

Fosaa, A.M., Dalsgarð J. \& Gaard E. 2006. Føroya Náttúra- Lívfrøðiligt margfeldi. Føroya Skúlabókagrunnur.

Greenland

Dorte Bugge Jensen \& Kim Diget Christensen (eds.). 2003. The Biodiversity of Greenland - a country study, Technical Report No. 55, Pinngortitalerifik, Grønlands Naturinstitut. 
Store Strandstræde 18

DK-1255 Copenhagen K

www.norden.org

\section{Nordic nature - trends towards 2010}

Examples of Nordic contributions towards the international biodiversity target 2010

The international target to slow and even halt the decline in biodiversity by the end of 2010 has been included in the Nordic Council of Ministers' Environmental Action Plan for 2009-2012. We already know that this goal will not be reached, in spite of the many actions big and small taken around the Nordic Region to help preserve and protect biodiversity. During the UN International Year of Biodiversity 2010 new goals will be defined and campaigns will be conducted to emphasise the importance of biodiversity to nature and people. The task of conserving biodiversity will also continue after the theme year 2010 .

The project Nordic nature - trends towards 2010 has presented examples illustrating the threats facing biodiversity together with conservation success stories, and also descriptions of conservation efforts that have not always produced the desired results. These reviews have been published as fact sheets in electronic format on the project's websites in all of the Nordic languages and in English. This publication compiles these published fact sheets, together with a summary of current trends in biodiversity in the Nordic Countries, as part of our region's contribution towards the 2010 biodiversity target and the goal of increasing awareness of the special significance of biodiversity. 